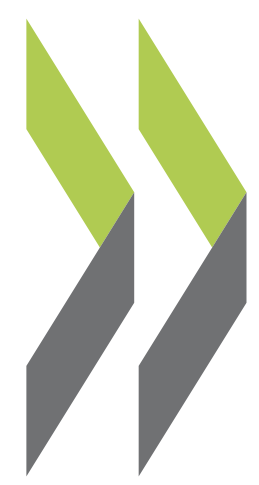

OECD Social, Employment and Migration Working Papers No. 127

\title{
The Labour Market Integration of Immigrants and their Children in Austria
}

\section{Karolin Krause, Thomas Liebig}


Organisation de Coopération et de Développement Économiques

Organisation for Economic Co-operation and Development

10-Nov-2011

DIRECTORATE FOR EMPLOYMENT, LABOUR AND SOCIAL AFFAIRS

English - Or. English

EMPLOYMENT, LABOUR AND SOCIAL AFFAIRS COMMITTEE

OECD SOCIAL, EMPLOYMENT AND MIGRATION PAPERS, NO. 127

THE LABOUR MARKET INTEGRATION OF IMMIGRANTS

AND THEIR CHILDREN IN AUSTRIA

Karolin Krause and Thomas Liebig

$J 13, J 15, J 21, J 24, J 61, J 68, J 7, J 8$

JT03311301

Document complet disponible sur OLIS dans son format d'origine

Complete document available on OLIS in its original format 


\title{
DIRECTORATE FOR EMPLOYMENT, LABOUR AND SOCIAL AFFAIRS
}

www.oecd.org/els

\section{OECD SOCIAL, EMPLOYMENT AND MIGRATION WORKING PAPERS}

\author{
www.oecd.org/els/workingpapers
}

This series is designed to make available to a wider readership selected labour market, social policy and migration studies prepared for use within the OECD. Authorship is usually collective, but principal writers are named. The papers are generally available only in their original language - English or French - with a summary in the other.

Comment on the series is welcome, and should be sent to the Directorate for Employment, Labour and Social Affairs, 2, rue André-Pascal, 75775 PARIS CEDEX 16, France.

The opinions expressed and arguments employed here are the responsibility of the author(s) and do not necessarily reflect those of the OECD.

Applications for permission to reproduce or translate all or part of this material should be made to:

\author{
Head of Publications Service \\ OECD \\ 2, rue André-Pascal \\ 75775 Paris, CEDEX 16 \\ France
}

Copyright OECD 2010 
DELSA/ELSA/WD/SEM(2011)12

\section{ACKNOWLEDGEMENTS}

This report has been written by Karolin Krause and Thomas Liebig from the International Migration Division of the OECD Directorate for Employment, Labour and Social Affairs. The study was prepared in close consultation with Norbert Bichl (Counselling Centre for Migrants, Vienna), who provided valuable advice and comments at all stages of the preparation process. The report also benefited from a contribution by Helmut Hofer (Institute for Higher Studies, Vienna).

The authors are grateful for the support and advice received from Jean-Christophe Dumont, JeanPierre Garson, Yassine Khoudja, Georges Lemaître, John Martin and Stefano Scarpetta from the OECD Directorate for Employment, Labour and Social Affairs. A draft of this report was presented and discussed at the OECD Working Party on Migration (WPM) on 9 June 2011. The authors thank the participants to the WPM for valuable comments.

The preparation of this report would not have been possible without the support of the Austrian national authorities, in particular Sigrid Röhrich, Heinz-Peter Kutrowatz and Johannes Schweighofer (Federal Ministry for Labour, Social Affairs and Consumer Protection). The authors are also grateful to Statistics Austria, in particular Beatrix Wiedenhofer-Galik, as well as all stakeholders met during the missions to Austria, for the information provided.

Contact:

Thomas Liebig

International Migration Division

Directorate for Employment, Labour and Social Affairs

2 , rue André-Pascal

F-75775 Paris Cedex 16

Tel. +33-1-45 249068

Thomas.Liebig@oecd.org

www.oecd.org/migration 


\section{EXECUTIVE SUMMARY}

With $17 \%$ of the working-age population in 2010 being foreign-born, Austria has one of the largest shares of working-age immigrants in the OECD. As in other European OECD countries, the migration landscape in Austria has been shaped by the recruitment of low-educated labour migrants prior to the first oil shock and subsequent family migration. Even more important were the fall of the Iron Curtain in the late 1980s and the conflicts in the former Yugoslavia, which triggered large-scale migration movements to Austria. More than three quarters of all migrants of working-age currently residing in Austria have arrived since the former event, with most entering between 1988 and 1995.

Following these large inflows, a number of measures were introduced in the early and mid-1990s which kept many newly-arriving immigrants from lower-income countries out of the labour market. These measures appear to have contributed to the unfavorable outcomes of some migrant groups, in particular immigrant women. Although most of these obstacles have been gradually removed, some are still in place for a number of permanent-type immigrants. Abandoning the remaining restrictions would enhance transparency of the system.

In spite of its large immigrant population, the overall framework for integration in Austria is less developed than in the other OECD countries that have been under review by the OECD thus far. In particular, the labour market integration of immigrants and their children in Austria has only recently received significant policy attention. This is partly due to the fact that the labour market outcomes of immigrants have been quite good until about a decade ago.

The immigrant population is strongly concentrated in Vienna, where labour market conditions are less favourable than in the remainder of Austria. Accounting for this geographical concentration strongly reduces the differences in labour market outcomes between immigrants and the native-born population.

Indeed, at first sight, the overall labour market integration outcomes of immigrants are not unfavourable in international comparison. This seems to be mainly attributable to overall labour market conditions and the fact that Austria has a rather favourable mix of origin countries of migrants. More than half of the current immigrant population of working-age is from high-income OECD countries and large part of the remainder are from one of the successor countries of the neighbouring former Yugoslavia, with whom Austria has many historical and cultural ties. Both of these groups of migrants also tend to have relatively favourable labour market outcomes elsewhere. Other groups, in particular women from lowerincome countries, have outcomes which are not as good in international comparison. Overall, the low integration outcomes of women - both immigrants and their children - in terms of education and labour market - merit further policy attention.

The Austrian labour market places strong importance on formal qualifications which poses particular challenges for immigrants. First, they are strongly overrepresented among the low-educated, which hampers their employment prospects. Second, those who have qualifications from their origin countries find them discounted on the Austrian labour market. The incidence of migrants working in jobs that would only require a qualification below the education level which they have obtained is among the highest in the 
OECD. Formal recognition seems to help in this respect, but is a route rarely taken by immigrants. The reasons for this merit closer scrutiny, and remedial action needs to be taken.

In recent years, a number of measures have been introduced to make better use of immigrants' skills, in the context of a larger effort to augment Austria's supply of skilled labour. These include programmes to train immigrants for skilled occupations in which there are labour shortages. There is some evidence that these have been particularly effective. In addition, starting in 2012, immigrants will be specially targeted by the Public Employment Service (AMS). The social partners, who play a particularly important role in the labour market integration of immigrants in Austria, have also put forward a number of measures, such as counselling services and a mentorship programme, to complement the standard tools of the AMS.

In contrast to other OECD countries, Austria does not have a structured integration programme for new arrivals at the federal level. The single main budget item which can be directly attributed to immigrants' labour market integration is language training. Efforts in this domain, which are largely financed by the AMS, have recently been stepped up significantly. However, relatively few immigrants make their way directly into jobs after participation in these courses. The reasons for this merit closer investigation, given the significant investment made in language training.

Apart from language training, there are no integration measures at the federal level which are directly targeted at immigrants. Offers by non-governmental organisations and at the sub-national level partly compensate for this, but these are often small-scale and project-based, making an assessment difficult.

A major shortcoming is the lack of effective policy co-ordination at the federal level, and it is urgent to tackle this. The lack of co-ordination is particularly visible in the area of the recognition of foreign qualifications, where there is a multitude of different actors which hampers transparency of the system. Effective policy guidance has also been held back by a significant lack of research and evaluation regarding immigrants' labour market integration. This deficit has been partly due to the absence of data on immigrants and their children. As more and better data become available, tackling the deficit in research and evaluation should be a next step.

Particularly worrisome are the rather poor results for the offspring of immigrants. These are now gradually entering the labour market and, compared with the children of natives, are four times more likely to find themselves among the low-educated who are neither in employment nor in education. To tackle this significant challenge, a co-ordinated effort is needed. This should include a focus on pre-school education at the critical ages of three and four, as well as measures targeted at a better representation of children of immigrants in vocational colleges, apprenticeships and in the public sector, where children of immigrants are currently largely underrepresented.

Even those children of immigrants who manage to obtain a higher Austrian educational degree have difficulties in finding employment, pointing to structural obstacles in the Austrian labour market that are specific to immigrants and their children, including discrimination. They would thus benefit from the introduction of more pro-active anti-discrimination and diversity measures.

All things considered, there has been significant progress in Austria's integration framework over the past few years and recent initiatives go in the right direction, but integration policies in Austria still lag behind those of other OECD countries. To overcome the remaining shortcomings and further improve the labour market outcomes of immigrants and their children, a number of measures are recommended.

Keywords: Integration, immigrants, labour market, Austria, skills, recognition, discrimination 


\section{Summary of the main policy recommendations}

\section{A) Improve the framework for a coherent and effective integration policy}

- Establish at the federal level a structure for better experience-sharing and co-ordination of integration policy, acknowledging that integration is a cross-cutting issue involving many different actors.

- Overcome the current deficit in research and evaluation, among others through the development and exploitation of longitudinal data sources.

\section{B) Strengthen integration offers for immigrants}

- Make sure that immigrant women who are far from the labour market are reached by integration offers.

- Implement a structured integration programme for new arrivals, based on the individual's needs, with a clear focus on labour market integration.

- Extend the current offers for skills- and vocation-specific language training and make sure that the language training provided by different stakeholders is co-ordinated.

- Promote immigrants' participation in « inplacement foundations » which train the unemployed in accordance with the skills needs of enterprises.

\section{C) Pay more attention to early labour market entry}

- $\quad$ Reduce the complexity of the residence and work permit system and abolish the remaining obstacles to the labour market access of permanent-type immigrants.

- Consider giving asylum seekers more rights to work, at least for those whose request is not apparently unfounded.

\section{D) Make better use of the skills of migrants}

- Make the possibilities for the recognition of foreign qualifications more widely known and enhance transparency of the recognition process, ideally by the implementation of one-stop shops including all the different types of qualifications.

- $\quad$ Develop and implement tools for the accreditation of prior learning, with a specific focus on immigrants and in close co-operation with the social partners.

\section{E) Pay more attention to the needs of the children of immigrants}

- Make sure that restrictions regarding family migration do not hamper the integration process of the children of immigrants.

- Seek to increase the participation of children of immigrants in pre-school education at the critical ages of three and four.

- $\quad$ Provide more structured German language training to the children of immigrants and re-consider the current focus on "mother-tongue education". 


\section{Summary of the main policy recommendations (cont'd)}

- Implement special measures for young immigrants who arrive at the end of obligatory schooling or just thereafter, to make sure that they obtain an Austrian qualification that is recognised and valued in the labour market.

- Investigate the causes for the low outcomes of the 15-24 year old children of immigrants compared with their older peers, and take appropriate action.

- $\quad$ Promote access to vocational colleges and apprenticeships for the children of immigrants.

- Put more effort into increasing the employment prospects for the children of immigrants in the public sector.

\section{F) Streamline and strengthen the framework for anti-discrimination}

- Make the anti-discrimination framework more visible to immigrants and inform them about their rights.

- Conduct an experimental testing study to capture the incidence of discrimination in hiring, and communicate the findings widely to raise awareness about the issue.

- $\quad$ Consider more pro-active measures to tackle discrimination, such as increasing recourse to diversity policy tools. 


\section{RÉSUMÉ}

En 2010, avec $17 \%$ de la population en âge de travailler née à l'étranger, l'Autriche compte l'une des plus fortes proportions d'immigrés d'âge actif au sein de l'OCDE. Comme dans d'autres pays européens de l'OCDE, le panorama des migrations en Autriche a été marqué, avant le premier choc pétrolier, par le recrutement de travailleurs immigrés ayant un faible niveau d'instruction, et par des migrations ultérieures au titre du regroupement familial. La chute du Rideau de fer, à la fin des années 80, et les conflits en exYougoslavie qui ont provoqué des mouvements migratoires à grande échelle à destination de l'Autriche, ont joué un rôle encore plus important. Plus des trois quarts de tous les immigrés en âge de travailler résidant actuellement en Autriche sont arrivés depuis le premier de ces événements, la plupart d'entre eux étant entrés sur le territoire autrichien entre 1988 et 1995.

Suite à ces arrivées massives, plusieurs mesures ont été mises en place, au début et vers le milieu des années 90, qui ont eu pour effet d'empêcher un grand nombre d'immigrés en provenance de pays à faible revenu d'accéder au marché du travail. Ces mesures semblent avoir contribué aux mauvais résultats enregistrés par certains groupes d'immigrés, notamment les femmes. Bien que la plupart de ces obstacles aient été progressivement éliminés, certaines de ces mesures s'appliquent encore à bon nombre d'immigrés ayant un statut de résident permanent. L'abandon des restrictions qui subsistent améliorerait la transparence du système.

Malgré l'importance de la population immigrée, le cadre global d'intégration de l'Autriche est moins développé que dans les pays de l'OCDE ayant fait l'objet d'une revue. Ainsi, en Autriche, ce n'est que récemment que l'intégration des immigrés et de leurs enfants sur le marché du travail a réellement attiré l'attention des pouvoirs publics. Cela tient notamment au fait que les résultats obtenus par les immigrés sur le marché du travail ont été plutôt satisfaisants jusqu'aux environs de la dernière décennie.

La population immigrée est fortement concentrée à Vienne où la situation du marché du travail est moins favorable que dans le reste de l'Autriche. La prise en compte de cette concentration géographique réduit considérablement les différences de performance observées sur le marché du travail entre immigrés et population autochtone.

En effet, de prime abord, les résultats globaux obtenus par les immigrés quant à leur intégration sur le marché du travail n'ont rien à envier à ceux enregistrés au niveau international. Cela tient essentiellement à la situation générale du marché du travail et au panachage assez favorable des pays d'origine des immigrés installés en Autriche. Dans sa composition actuelle, plus de la moitié de la population immigrée en âge de travailler, provient de pays de l'OCDE à revenu élevé et une grande partie du reste de cette population provient de pays voisins issus de l'ex-Yougoslavie avec lesquels l'Autriche entretient de nombreux liens historiques et culturels. Ces deux groupes de migrants obtiennent aussi des résultats assez favorables sur le marché du travail d'autres pays. D'autres groupes, notamment les femmes issues de pays à faible revenu, obtiennent des résultats qui ne sont pas aussi bons au regard de ceux enregistrés dans d'autres pays. Dans l'ensemble, qu'il s'agisse de l'éducation ou de l'intégration sur le marché du travail, les faibles résultats obtenus par les femmes - aussi bien par les immigrées elles-mêmes que par leurs enfants -méritent une plus grande attention de la part des pouvoirs publics.

En Autriche, les employeurs accordent une grande importance aux qualifications formelles, ce qui pose des défis particuliers aux immigrés. Tout d'abord, ils sont fortement surreprésentés parmi les 
personnes peu qualifiées, ce qui nuit à leurs perspectives d'emploi. D'autre part, ceux qui ont acquis des qualifications dans leur pays d'origine, s'aperçoivent que celles-ci sont peu prisées sur le marché du travail autrichien. L'incidence d'immigrés occupant des postes exigeant un niveau de qualification inférieur à celui qu'ils possèdent est l'une des plus élevées parmi les pays de l'OCDE. L'obtention d'une reconnaissance officielle semble utile à cet égard, mais c'est là une voie rarement suivie par les immigrés. Il serait intéressant de déterminer pourquoi il en est ainsi et de prendre les mesures nécessaires qui s'imposent.

Ces dernières années, plusieurs mesures ont été mises en place pour tirer un meilleur parti des qualifications des immigrés dans le contexte plus large des efforts déployés par l'Autriche pour accroître son offre de main-d'œuvre qualifiée. Parmi ces mesures, on trouve des programmes de formation des immigrés à des emplois qualifiés dans des domaines où existent des pénuries de main-d'œuvre. Il semblerait que ces programmes aient été particulièrement efficaces. En outre, à partir de 2012, les immigrés seront particulièrement ciblés par le Service public de l'emploi (AMS). Les partenaires sociaux, qui jouent un rôle particulièrement important en Autriche quant à l'intégration des immigrés sur le marché du travail, ont également proposé un certain nombre de mesures, notamment des services de conseils et un programme de mentorat, qui viennent compléter les moyens utilisés habituellement par l'AMS.

Contrairement à d'autres pays de l'OCDE, l'Autriche ne dispose pas, au niveau fédéral, d'un programme structuré d'intégration des nouveaux arrivants. Le seul poste du budget principal qui puisse être directement imputé à l'intégration des immigrés sur le marché du travail est celui de la formation linguistique. Largement financés par l'AMS, les efforts déployés dans ce domaine ont récemment été considérablement renforcés. Toutefois les immigrés qui réussissent à trouver directement du travail après avoir suivi de tels cours sont relativement peu nombreux. Les raisons mériteraient d'en être étudiées de plus près, étant donné l'importance de l'investissement consacré à la formation linguistique.

En dehors de la formation linguistique, il n'existe pas, au niveau fédéral, de mesures d'intégration ciblant directement les immigrés. Ce que les organisations non gouvernementales et les autorités infranationales offrent compense en partie cette lacune, mais leurs activités sont souvent basées sur des projets et menées à petite échelle, ce qui rend leur évaluation difficile.

L'absence de coordination efficace des politiques au niveau fédéral constitue une faiblesse majeure à laquelle il est urgent de remédier. Le manque de coordination est particulièrement visible dans le domaine de la reconnaissance des diplômes étrangers, domaine dans lequel opèrent une multitude d'acteurs différents, ce qui nuit à la transparence du système. L'absence notoire de recherche et d'évaluation consacrées à l'intégration des immigrés sur le marché du travail s'oppose également à l'élaboration de directives efficaces sur le plan des politiques. Ce déficit est notamment dû au manque de données relatives aux immigrés et à leurs enfants. Dès lors que l'on disposera de données plus nombreuses et de meilleure qualité, il faudra passer à l'étape suivante qui consiste à réduire le déficit existant en matière de recherche et d'évaluation.

Les piètres résultats des enfants d'immigrés sont particulièrement préoccupants. Ceux-ci font maintenant progressivement leur entrée dans la vie active et, par rapport aux enfants des autochtones, ils sont quatre fois plus nombreux à se retrouver parmi les moins qualifiés n'ayant ni emploi, ni diplôme. Pour relever cet important défi, il faut déployer des efforts coordonnés. Ces efforts doivent porter plus particulièrement sur l'enseignement préscolaire, aux âges critiques de trois et quatre ans, et s'accompagner également de mesures visant une meilleure représentation des enfants d'immigrés dans les établissements de formation professionnelle, les centres d'apprentissage et le secteur public où cette population est actuellement sous-représentée. 


\section{DELSA/ELSA/WD/SEM(2011)12}

Même les enfants d'immigrés qui réussissent à obtenir un diplôme de l'enseignement supérieur autrichien éprouvent des difficultés à trouver un emploi, ce qui donne à penser qu'il existe, sur le marché du travail autrichien, des obstacles structurels propres aux immigrés et à leurs enfants, notamment en matière de discriminations. Ils auraient donc tout à gagner de la mise en place de mesures plus volontaristes en faveur de la diversité et de la lutte contre les discriminations.

Tout bien considéré, le cadre d'intégration autrichien a beaucoup progressé ces dernières années, et les initiatives prises récemment vont dans la bonne direction, mais les politiques d'intégration autrichiennes sont à la traîne par rapport à celles menées dans d'autres pays de l'OCDE. Pour combler les lacunes qui subsistent encore et améliorer les performances des immigrés et de leurs enfants sur le marché du travail, un certain nombre de mesures sont recommandées.

Mots clés: Intégration, immigrés, marché du travail, Autriche, qualifications, reconnaissance, discrimination

\section{Résumé des principales recommandations politiques}

\section{A) Améliorer le cadre d'une politique d'intégration cohérente et efficace}

- Créer, au niveau fédéral, une structure permettant de mieux coordonner la politique d'intégration et de partager plus facilement les expériences dans ce domaine, en reconnaissant que l'intégration est une question transversale qui requiert l'intervention de nombreux acteurs différents.

- Remédier aux carences qui existent actuellement en matière de recherche et d'évaluation, en développant et en exploitant les sources de données longitudinales.

B) Renforcer les possibilités d'intégration offertes aux immigrés

- S'assurer que les femmes immigrées éloignées du marché du travail soient touchées par les mesures d'intégration proposées.

- Mettre en œuvre, à l'intention des nouveaux arrivants, un programme d'intégration structuré qui réponde aux besoins des individus et dont l'objectif explicite est l'intégration sur le marché du travail.

- Élargir les programmes actuellement proposés en matière de formation linguistique correspondant à des qualifications et des formations professionnelles données et veiller à la coordination des formations linguistiques proposées par les différentes parties prenantes.

- Favoriser la participation des immigrés à des «fondations de placement » qui forment les chômeurs en fonction des compétences dont les entreprises ont besoin.

\section{C) Accorder davantage d'attention à l'entrée rapide sur le marché du travail}

- Simplifier le système des permis de résidence et de travail et abolir les obstacles qui s'opposent encore à l'accès au marché du travail des immigrés ayant un statut de résident permanent.

- Envisager de donner aux demandeurs d'asile plus de droits pour travailler, au moins à ceux dont la requête ne semble pas infondée. 


\section{Résumé des principales recommandations politiques (suite)}

\section{D) Tirer un meilleur parti des compétences des immigrés}

- Faire mieux connaître les possibilités de reconnaissance des diplômes étrangers et renforcer la transparence du processus de reconnaissance, de préférence par la mise en place de guichets uniques, pour l'ensemble des différents types de qualifications.

- Mettre au point et appliquer des mécanismes d'accréditation des apprentissages antérieurs visant plus particulièrement les immigrés, en étroite coopération avec les partenaires sociaux.

\section{E) Accorder davantage d'attention aux besoins des enfants d'immigrés}

- Veiller à ce que les restrictions concernant les migrations familiales ne compromettent pas le processus d'intégration des enfants d'immigrés.

- S'efforcer d'accroître la participation des enfants d'immigrés à l'enseignement préscolaire aux âges critiques de trois et quatre ans.

- Offrir aux enfants d'immigrés une formation plus structurée en matière d'apprentissage de l'allemand et réexaminer la priorité accordée actuellement à l'enseignement de la langue maternelle.

- $\quad$ Appliquer des mesures spéciales à l'intention des jeunes migrants qui arrivent à l'âge de fin de scolarité obligatoire ou juste après, afin de s'assurer qu'ils obtiennent un diplôme autrichien reconnu et prisé sur le marché du travail.

- Rechercher quelles sont les causes des piètres performances des enfants d'immigrés âgés de 15 à 24 ans, comparés aux résultats de leurs homologues plus âgés, et prendre les mesures qui s'imposent.

- Encourager l'accès des enfants d'immigrés aux établissements de formation professionnelle et aux centres d'apprentissage.

- Renforcer les efforts déployés pour accroître les perspectives d'emploi des enfants d'immigrés dans le secteur public.

\section{F) Rationaliser et renforcer le cadre mis en place pour lutter contre les discriminations}

- $\quad$ Rendre le cadre de lutte contre les discriminations plus visible pour les immigrés et les informer de leurs droits.

- Effectuer une étude expérimentale pour déterminer l'incidence des discriminations dans le processus de recrutement, et diffuser largement les conclusions de cette étude afin de provoquer une prise de conscience à ce sujet.

- Envisager des mesures plus volontaristes pour lutter contre les discriminations, en ayant notamment plus souvent recours à des instruments d'action politique en faveur de la diversité. 


\section{ZUSAMMENFASSUNG}

$17 \%$ der österreichischen Bevölkerung im erwerbsfähigen Alter wurden in einem anderen Land geboren, womit Österreich innerhalb der OECD 2010 einen der höchsten Anteile von MigrantInnen im Erwerbsalter aufwies. Wie in anderen europäischen OECD-Ländern wurde Österreichs Migrationslandschaft durch die Anwerbung gering qualifizierter ArbeitsmigrantInnen vor dem ersten Ölschock und durch späteren Familiennachzug geprägt. Noch bedeutsamer waren jedoch der Fall des Eisernen Vorhangs Ende der 1980er-Jahre und die Konflikte im ehemaligen Jugoslawien, die starke Wanderungsbewegungen nach Österreich auslösten. Mehr als drei Viertel aller derzeit in Österreich ansässigen MigrantInnen im Erwerbsalter kamen nach ersterem Ereignis, die meisten davon zwischen 1988 und 1995.

Infolge dieser großen Zuwanderungsströme wurden Anfang und Mitte der 1990er-Jahre diverse Maßnahmen eingeführt, die viele der Neuzuwanderer aus einkommensschwächeren Ländern vom Arbeitsmarkt fernhielten. Diese Maßnahmen scheinen zu den ungünstigen Arbeitsmarktergebnissen einiger Migrationsgruppen, insbesondere jener der zugewanderten Frauen, beigetragen zu haben. Auch wenn die meisten dieser Hindernisse schrittweise abgebaut wurden, blieben einige davon für bestimmte auf Dauer niedergelassene MigrantInnen bestehen. Die Abschaffung dieser verbliebenen Beschränkungen würde die Transparenz des Systems erhöhen.

Trotz eines großen Bevölkerungsanteils mit Migrationshintergrund ist insgesamt der Integrationsrahmen in Österreich weniger entwickelt als in den anderen bislang von der OECD überprüften OECD-Ländern. Insbesondere die Eingliederung von MigrantInnen und deren Kindern in den österreichischen Arbeitsmarkt erfuhr erst in jüngster Zeit vermehrt politische Aufmerksamkeit. Dies ist zum Teil auf die Tatsache zurückzuführen, dass sich MigrantInnen bis vor etwa zehn Jahren relativ gut auf diesem Arbeitsmarkt behaupteten.

MigrantInnen sind besonders stark in Wien vertreten, wo die Arbeitsmarktbedingungen weniger günstig sind als im Rest Österreichs. Wird diese geographische Konzentration berücksichtigt, vermindern sich die Unterschiede in den Arbeitsmarktergebnissen zwischen MigrantInnen und der in Österreich geborenen Bevölkerung stark.

Auf den ersten Blick sind die Ergebnisse der Arbeitsmarktintegration von MigrantInnen im internationalen Vergleich gar nicht ungünstig. Dies scheint vor allem auf die Arbeitsmarktlage insgesamt sowie auf die Tatsache zurückzuführen zu sein, dass die in Österreich lebenden MigrantInnen eine relativ günstige Zusammensetzung der Herkunftsländer aufweisen. Über die Hälfte der aktuellen Zuwanderungsbevölkerung im erwerbsfähigen Alter kommt aus einkommensstarken OECD-Ländern und der Rest mehrheitlich aus den Nachfolgestaaten Jugoslawiens, mit denen Österreich historisch wie kulturell viele Anknüpfungspunkte hat. Diese beiden Migrationsgruppen behaupten sich tendenziell auch auf anderen Arbeitsmärkten relativ gut. Andere Gruppen, und hier insbesondere Frauen aus einkommensschwächeren Ländern, sind im internationalen Vergleich beruflich weniger gut integriert. Insgesamt sollte sich die Politik verstärkt der geringen schulischen und beruflichen Integrationsergebnisse von Frauen mit Migrationshintergrund - und zwar sowohl bei Zuwanderinnen selbst als auch bei deren in Österreich geborenen Töchtern - annehmen. 
Auf dem österreichischen Arbeitsmarkt wird formellen Qualifikationen große Bedeutung beigemessen, was für MigrantInnen eine besondere Herausforderung darstellt. Erstens sind sie unter den gering Qualifizierten stark überrepräsentiert und damit in ihren Beschäftigungsaussichten beeinträchtigt. Zweitens sind MigrantInnen, die Qualifikationen aus ihrem Herkunftsland vorweisen können, damit konfrontiert, dass diese auf dem österreichischen Arbeitsmarkt wenig gelten. Der Anteil von MigrantInnen, die einer Beschäftigung nachgehen, die unter ihrem eigentlich erreichten Qualifikationsniveau liegt, ist einer der höchsten in der OECD. Eine formelle Anerkennung scheint hilfreich, doch nutzen ImmigrantInnen diese Möglichkeit nur selten. Die Gründe dafür verdienen eingehender untersucht, und entsprechende Maßnahmen getroffen zu werden.

In den letzten Jahren wurden in Zusammenhang mit generellen Bemühungen, das Fachkräfteangebot in Österreich zu erhöhen, auch diverse Maßnahmen ergriffen, um die Qualifikationen von MigrantInnen besser zu nutzen. Dazu gehören spezielle Qualifizierungsmaßnahmen, bei denen MigrantInnen für Berufe ausgebildet werden, in denen ein Fachkräftemangel herrscht. Es gibt einige Hinweise darauf, dass diese Maßnahmen besonders wirksam waren. Außerdem werden MigrantInnen ab 2012 eine spezielle Zielgruppe des Arbeitsmarktservice (AMS) sein. Auch die Sozialpartner, die in Österreich eine besonders wichtige Rolle bei der Arbeitsmarktintegration von MigrantInnen spielen, haben eine Reihe von $\mathrm{Maßnahmen} \mathrm{eingeführt,} \mathrm{wie} \mathrm{etwa} \mathrm{Beratung} \mathrm{und} \mathrm{Mentoring,} \mathrm{um} \mathrm{das} \mathrm{gängige} \mathrm{AMS-Instrumentarium} \mathrm{zu}$ ergänzen.

Im Gegensatz zu anderen OECD-Ländern hat Österreich auf Bundesebene kein strukturiertes Integrationsprogramm für Neuzuwanderer. Der einzige größere Budgetposten, der unmittelbar der Arbeitsmarkteingliederung von MigrantInnen zugeordnet werden kann, betrifft die Deutschkurse. Diese großteils vom AMS geförderten Maßnahmen wurden in letzter Zeit stark ausgeweitet, doch verhältnismäßig wenige MigrantInnen schaffen den direkten Übertritt von der Kursteilnahme ins Erwerbsleben. Angesichts der signifikanten Investitionen in Deutschkurse sollten die Gründe dafür eingehender untersucht werden.

Abgesehen von Sprachkursen gibt es auf Bundesebene keine unmittelbar auf MigrantInnen abgestellten Integrationsmaßnahmen. Angebote von Nichtregierungsorganisationen oder von unterhalb der Bundesebene angesiedelten öffentlichen Einrichtungen sorgen hier zum Teil für Ausgleich, doch sind diese zumeist kleinteilig und projektorientiert, was ihre Bewertung schwierig macht.

Ein wesentliches und dringend $\mathrm{zu}$ behebendes Manko ist das Fehlen einer wirksamen Maßnahmenkoordination auf Bundesebene. Insbesondere bei der Anerkennung ausländischer Qualifikationen macht sich die mangelnde Koordination bemerkbar. In diesem Bereich gibt es viele verschiedene Akteure, wodurch die Transparenz des Systems beeinträchtigt wird. Effektive politische Vorgaben wurden auch durch den ausgeprägten Mangel an Forschung und Evaluation der Arbeitsmarktintegration von MigrantInnen behindert. Dieses Defizit ist teilweise durch fehlende Daten über MigrantInnen und deren Nachkommen bedingt. Da nun zusehends mehr und bessere Daten zur Verfügung stehen, sollte in einem nächsten Schritt dieses Forschungs- und Evaluierungsdefizit behoben werden.

Besonders besorgniserregend sind die relativ schwachen Ergebnisse der Kinder von MigrantInnen. Sie treten nun langsam ins Erwerbsleben ein, sind aber im Vergleich zu AltersgenossInnen ohne Migrationshintergrund viermal so häufig unter den gering Qualifizierten zu finden, die weder in Beschäftigung noch in Ausbildung sind. Um diese große Herausforderung in Angriff zu nehmen, bedarf es eines koordinierten Vorgehens. Dazu gehören die spezifische Förderung der vorschulischen Bildung im kritischen Alter von drei und vier Jahren sowie gezielte Maßnahmen zur Anhebung des Anteils von Jugendlichen mit Migrationshintergrund in berufsbildenden höheren Schulen, in der Lehrlingsausbildung und im öffentlichen Sektor, wo Nachkommen von MigrantInnen stark unterrepräsentiert sind. 
Aber sogar Kinder von MigrantInnen, die einen höheren Bildungsabschluss in Österreich erreichen, haben Schwierigkeiten bei der Arbeitssuche, was auf strukturelle Hindernisse auf dem österreichischen Arbeitsmarkt hinweist, die spezifisch ImmigrantInnen und deren Nachkommen betreffen, darunter auch Diskriminierung. Sie würden daher von der Einführung proaktiverer Antidiskriminierungs- und Diversitätsmaßnahmen profitieren.

Insgesamt wurden in den letzten Jahren signifikante Fortschritte beim Ausbau der österreichischen Rahmenbedingungen für Integration erzielt und die jüngsten Initiativen gehen in die richtige Richtung, doch hinkt die Integrationspolitik in Österreich noch immer hinter jener anderer OECD-Länder nach. Zur Beseitigung der verbliebenen Defizite und zur weiteren Verbesserung der Arbeitsmarktergebnisse von ImmigrantInnen und deren Nachkommen wird eine Reihe von Maßnahmen empfohlen.

Schlagwörter: Integration, Zuwanderer, Arbeitsmarkt, Österreich, Qualifikation, Anerkennung, Diskriminierung

\section{Zusammenfassung der wichtigsten Politikempfehlungen}

\section{A) Verbesserung der Rahmenbedingungen für eine kohärente und wirksame Integrationspolitik}

- Einrichtung einer Struktur auf Bundesebene zum besseren Erfahrungsaustausch und zur besseren Koordination der Integrationspolitik in Anerkennung der Tatsache, dass Integration eine Querschnittsmaterie mit vielen verschiedenen Akteuren ist.

- Beseitigung des derzeitigen Forschungs- und Evaluierungsdefizits, u.a. durch die Entwicklung und Auswertung von Längsschnittdatenquellen.

B) Verstärkte Integrationsangebote für MigrantInnen

- $\quad$ Sicherstellen, dass erwerbsferne zugewanderte Frauen durch Integrationsangebote erreicht werden.

- Umsetzung eines strukturierten Integrationsprogramms für Neuzuwanderer, das von individuellen Bedürfnissen ausgeht und einen deutlichen Schwerpunkt auf Arbeitsmarktintegration legt.

- Ausbau der aktuellen qualifikations- und berufsspezifischen Deutschkursangebote und Koordination der von verschiedenen Akteuren gestalteten Sprachkurse.

- Verstärkte Einbeziehung von MigrantInnen in Implacementstiftungen, die Arbeitslose bedarfsgerecht für die Personalerfordernisse von Unternehmen ausbilden.

C) Mehr Augenmerk auf einen baldigen Eintritt ins Erwerbsleben

- Das System der Aufenthalts- und Arbeitsbewilligungen weniger komplex gestalten und die restlichen Hindernisse für den Arbeitsmarktzugang von auf Dauer niedergelassenen MigrantInnen beseitigen.

- Eventuell auch Asylwerberlnnen mehr Rechte auf Berufsausübung geben, zumindest jenen, deren Anträge nicht offenkundig unbegründet sind. 


\section{Zusammenfassung der wichtigsten Politikempfehlungen (Fortsetzung)}

\section{D) Bessere Nutzung der Fähigkeiten von MigrantInnen}

- Vermehrte Bekanntmachung der Möglichkeiten, im Ausland erworbene Qualifikationen in Österreich anerkennen zu lassen, und größere Transparenz im Anerkennungsverfahren selbst, idealerweise durch die Einrichtung von Anlaufstellen, die nach dem One-Stop-Shop-Prinzip für sämtliche Arten von Abschlüssen zuständig sind.

- Entwicklung und Umsetzung von Instrumenten zur Ankerkennung von nicht-formal und informell erworbenen Kompetenzen mit spezifischer Schwerpunktsetzung auf Migrantlnnen und in enger Zusammenarbeit mit den Sozialpartnern.

\section{E) Mehr Augenmerk auf die Bedürfnisse der Kinder von MigrantInnen}

- $\quad$ Sicherstellen, dass die für Familiennachzug geltenden Einschränkungen den Integrationsprozess der Kinder von MigrantInnen nicht behindern.

- Förderung der Teilnahme von Kindern von MigrantInnen an vorschulischer Bildung im kritischen Alter von drei und vier Jahren.

- $\quad$ Strukturiertere Deutsch-Sprachförderung für Kinder von MigrantInnen anbieten und den aktuellen Fokus auf "muttersprachlichen Unterricht" überdenken.

- $\quad$ Spezielle Maßnahmen für junge ImmigrantInnen, die gegen Ende ihrer Pflichtschulzeit oder kurz danach ankommen, um sicherzustellen, dass sie einen österreichischen Abschluss erwerben, der auf dem Arbeitsmarkt anerkannt und honoriert wird.

- $\quad$ Die Ursachen für das schlechte Abschneiden der 15-24-jährigen Jugendlichen mit Migrationshintergrund im Vergleich zu vorangegangenen Gruppen mit Migrationshintergrund untersuchen und entsprechende Gegenmaßnahmen einleiten.

- $\quad$ Förderung des Zugangs zu höheren berufsbildenden Schulen und Lehrstellen für Kinder von Migrantlnnen.

- Verstärkte Bemühungen zur Anhebung der Beschäftigungschancen für Kinder von Migrantlnnen im öffentlichen Sektor.

\section{F) Straffung und Stärkung des Antidiskriminierungsrahmens}

- Das Antidiskriminierungsrahmenwerk für MigrantInnen sichtbarer machen und Migrantlnnen über ihre Rechte aufklären.

- Durchführung einer experimentellen Untersuchung, um die Häufigkeit der Diskriminierung bei der Einstellung von Arbeitskräften zu testen, und Verbreitung der Ergebnisse, um das Bewusstsein für diese Thematik zu schärfen.

- $\quad$ Proaktivere Maßnahmen zur Beseitigung von Diskriminierung überlegen, wie etwa den vermehrten Einsatz von Diversitätsmaßnahmen. 


\section{TABLE OF CONTENTS}

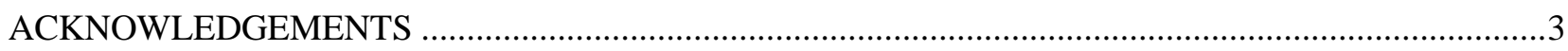

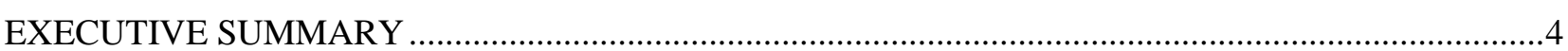

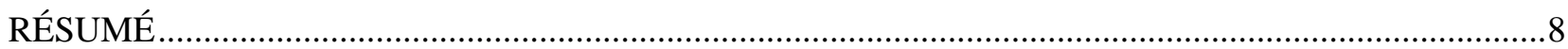

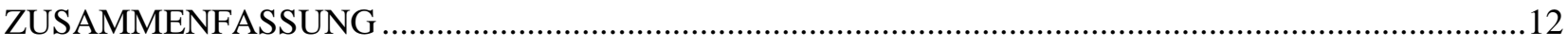

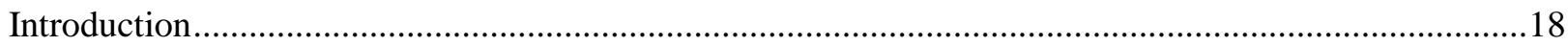

I. A first glance at the labour market outcomes of immigrants and their children..................................19

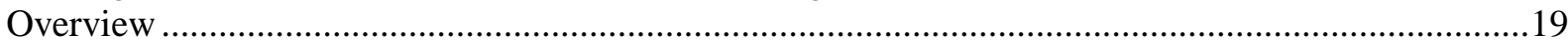

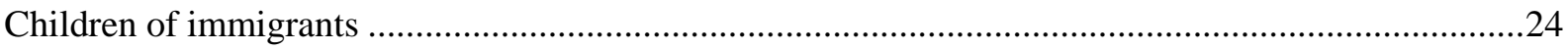

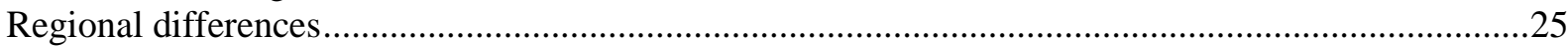

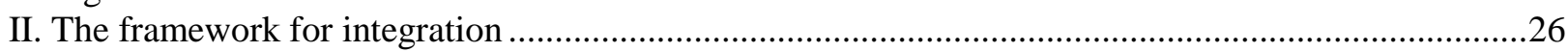

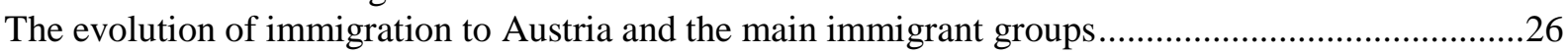

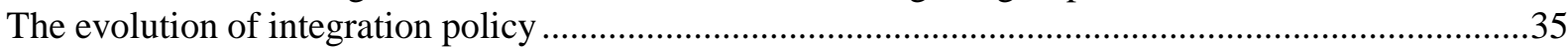

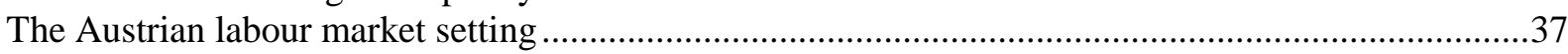

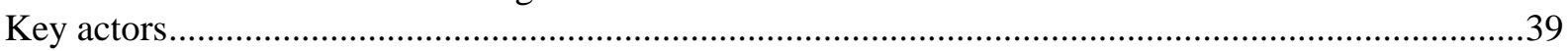

III. Migrants' position in the labour market: some key issues...........................................................42

The labour market access of immigrants and the outcomes of recent arrivals ......................................42

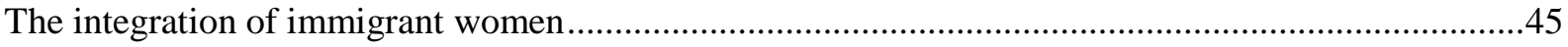

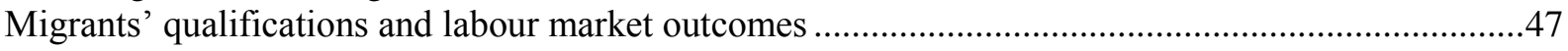

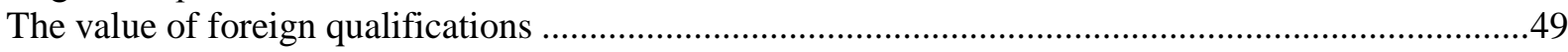

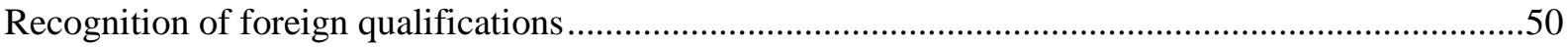

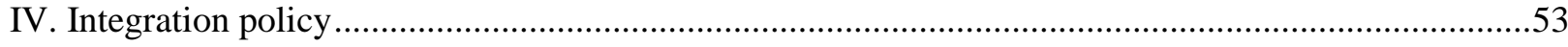

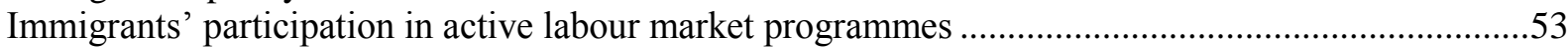

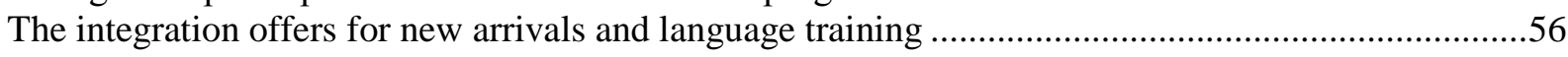

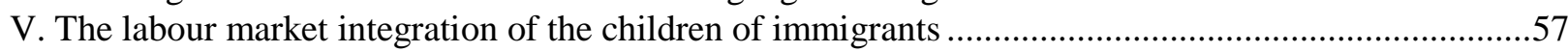

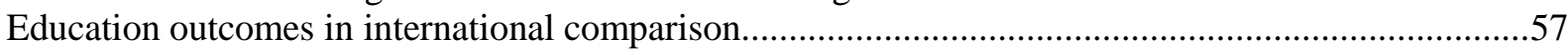

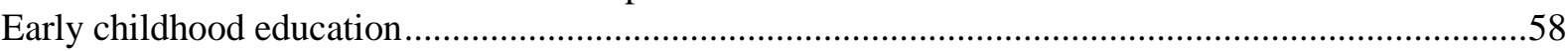

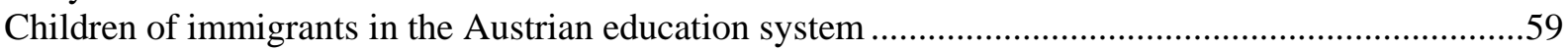

Policy measures to improve educational outcomes of the children of immigrants ...............................63

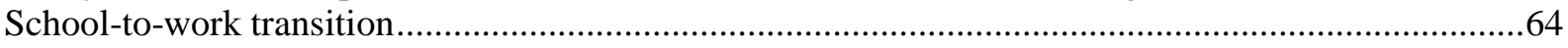

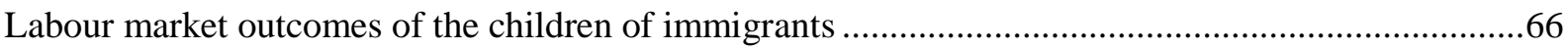

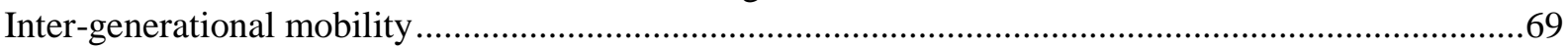

Policy measures to facilitate the labour market integration of immigrant offspring .............................71

VI. Sources of persisting disadvantage across generations - and possible remedies ...............................72

Networks and knowledge about labour market functioning................................................................

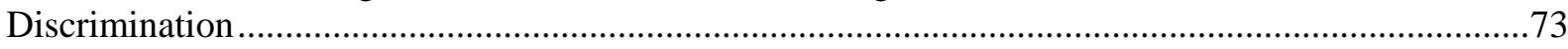

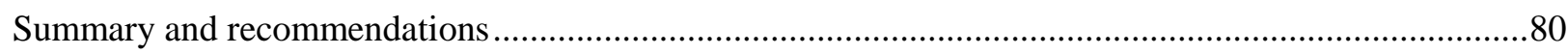




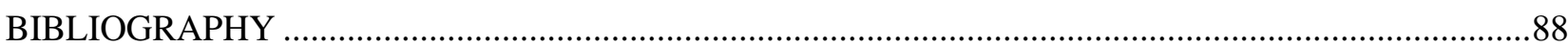

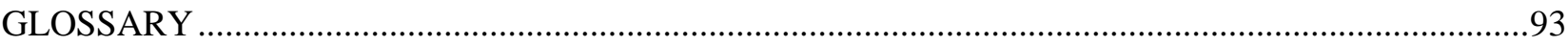

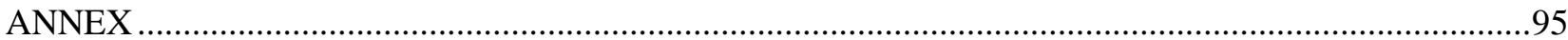

\section{Boxes}

Box 1. Data and research on immigrants and their children in Austria ..................................................21

Box 2. Immigrants from the former Yugoslavia and Turkey and their labour market

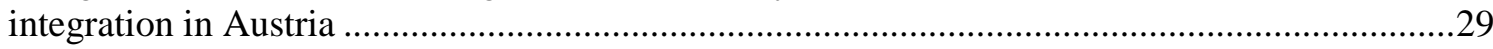

Box 3. A new labour migration system for Austria: the "Red-White-Red" card......................................35

Box 4. Integration activities of the social partners..............................................................................

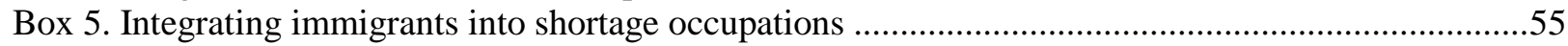

Box 6. Measures to facilitate the school-to-work transition of immigrants' offspring in Vienna ..............71

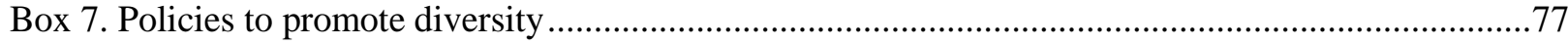




\section{THE LABOUR MARKET INTEGRATION OF IMMIGRANTS AND THEIR CHILDREN IN AUSTRIA}

\section{Introduction}

1. Until the mid-1980s, the share of migrants in Austria was relatively low in international comparison. With the fall of the Iron Curtain and the opportunities which it opened for East-West flows, migration to Austria increased rapidly. This was further fuelled by the break-up of the neighbouring former Yugoslavia, with which Austria has strong historical and cultural ties. The foreign population more than doubled between 1988 and 1993. The children of this large wave of immigration are now gradually entering the labour market, and the share of native-born children of immigrants in the population aged 1524 will more than double by 2020 , from $7 \%$ currently to $15 \%$.

2. In spite of the large population with an immigration background $-18.6 \%$ of the population have two foreign-born parents - the overall framework for integration is less well developed than in the other countries which have participated in the OECD Jobs for Immigrants reviews thus far. This is partly linked with the federal structure of the country, where a large number of actors at all government levels have a stake in integration. Where it has been active, integration policy has focused mainly on improving education outcomes and language skills - including mother-tongue education for the children of migrants.

3. The labour market integration of immigrants has to be seen in the context of a favourable overall labour market situation - Austria has one of the lowest unemployment rates in the OECD (4.5\% in the first quarter of 2011), and in particular youth unemployment is low in international comparison. Austria also combines a relatively flexible labour market with a strong role of the social partners. The latter has resulted in a rather unique governance of the labour market, with important implications for labour market integration.

4. Recently, the issue of integration has played a prominent role in public debate, and labour market integration has moved towards the centre stage. This is fuelled by evidence that the education and labour market outcomes of immigrants and their children in Austria are lagging behind those of natives.

5. Against this backdrop, the remainder of this report is structured as follows. Section I presents an overview of the key labour market outcomes of immigrants in Austria in international comparison, and their evolution over time. Section II analyses the framework for integration, that is, the evolution and current composition of the immigrant population, the evolution and main elements of integration policy, the labour market setting and the stakeholders involved in the integration of immigrants. Section III provides a detailed picture of immigrants in the labour market, including labour market access, the convergence of immigrants' outcomes towards those of natives over time, and the issue of immigrants' qualifications and their value and recognition in the labour market. Section IV analyses the main integration policy instruments. Section $\mathrm{V}$ reviews the school-to-work transition of the children of immigrants, followed by a glance at the evidence regarding discrimination in Section VI. The report ends with a summary and recommendations. 
DELSA/ELSA/WD/SEM(2011)12

\section{A first glance at the labour market outcomes of immigrants and their children}

\section{Overview}

6. Table 1 provides a first overview of the labour market outcomes of immigrants. As can be seen, the labour market outcomes of immigrants lag significantly behind those of the native-born in Austria. ${ }^{1}$ The differences are particularly large for women for whom the gaps in employment rates exceed ten percentage points. Although the unemployment rates of immigrants are not higher than elsewhere, these must be seen in the context of the overall low unemployment in Austria. Indeed, the incidence of unemployment is about 2.5 times higher among immigrants than among the native-born.

7. For both genders, immigrants from lower-income countries have less favourable outcomes. This group tends to have more difficulties in most OECD countries, partly because most of these have arrived for reasons other than employment (notably humanitarian) and have acquired their skills in a context that differs a lot from that in high-income OECD countries. Immigrants from lower income-countries account for just under 50\% of all immigrants in Austria. They thus account for a smaller share of immigrants than in most other countries in the comparison group where they generally account for the majority of the immigrant population, except in Switzerland and Denmark. Looking only at immigrants from these countries, Austria performs about average. Compared with the native-born, in particular the high incidence of unemployment stands out.

8. Reliable data on the labour market outcomes of the foreign-born population are only available for the years since 2004 (see Box 1). Figure 1 shows the evolution of the employment rate since then. ${ }^{2}$ For men, both the employment rates and the gaps vis-à-vis natives have remained broadly the same since 2004, although the pattern is somewhat erratic. For women, there has been some improvement in the employment rate, but this has been in parallel with an increase in employment of the native-born, and the aggregate gap has remained constant. One also observes a strong difference in the labour market performance of the different migrant groups. Women from the successor countries of the former Yugoslavia have employment rates that are just slightly lower than those of native-born Austrian women - although a gap has appeared over the past six to seven years. ${ }^{3}$ In contrast, differences are large and longstanding for immigrant women from Turkey. An interesting observation is the counter-cyclical increase of almost ten percentage points in the employment rate of women from lower-income countries (excluding ex-Yugoslavia and Turkey) during the crisis (i.e. between 2008 and 2010). This seems to be attributable at least in part to the so-called "added-worker effect", that is, spouses entering the labour market to compensate for the actual or probable employment loss of the principal migrant (see OECD, 2010).

1 The terms "immigrants" and "foreign-born" are used interchangeably in this text.

2 The term "employment rate" is used in this document synonymously with the employment-population ratio, that is, the percentage of employed in the respective age-cohort (unless stated otherwise, the working-age population aged 15-64).

3 For the sake of convenience, the terms "ex-Yugoslavia" or "former Yugoslavia" are occasionally used in this document to refer to the former Federal Republic of Yugoslavia and its successor countries. Slovenia, which is a successor country but now part of the European Union, is generally excluded from these figures, in line with Austrian statistics. 
Table 1. Labour force characteristics of immigrants and native-born, aged 15-64, selected OECD countries, 2008/2009 average

\begin{tabular}{|c|c|c|c|c|c|c|c|c|c|c|c|c|c|}
\hline & \multirow[b]{2}{*}{$\begin{array}{c}\% \text { of the } \\
\text { population } \\
\text { foreign- } \\
\text { born }\end{array}$} & \multirow[b]{2}{*}{$\begin{array}{l}\% \text { of the } \\
\text { foreign- } \\
\text { born from } \\
\text { a lower- } \\
\text { income } \\
\text { country }\end{array}$} & \multicolumn{3}{|c|}{ Participation rate } & \multicolumn{4}{|c|}{ Employment rate } & \multicolumn{4}{|c|}{ Unemployment rate } \\
\hline & & & $\begin{array}{c}\text { Native- } \\
\text { born }\end{array}$ & $\begin{array}{l}\text { Foreign- } \\
\text { born }\end{array}$ & $\begin{array}{c}\text { Foreign- } \\
\text { born } \\
\text { from a } \\
\text { lower- } \\
\text { income } \\
\text { country }\end{array}$ & $\begin{array}{c}\text { Native- } \\
\text { born }\end{array}$ & $\begin{array}{c}\text { Foreign- } \\
\text { born }\end{array}$ & $\begin{array}{c}\text { Foreign- } \\
\text { born } \\
\text { from a } \\
\text { lower- } \\
\text { income } \\
\text { country }\end{array}$ & $\begin{array}{l}\text { Difference } \\
\text { NB-FB in } \\
\% \text {-points }\end{array}$ & $\begin{array}{c}\text { Native- } \\
\text { born }\end{array}$ & $\begin{array}{l}\text { Foreign- } \\
\text { born }\end{array}$ & $\begin{array}{c}\text { Foreign- } \\
\text { born } \\
\text { from a } \\
\text { lower- } \\
\text { income } \\
\text { country }\end{array}$ & $\begin{array}{l}\text { Difference } \\
\text { FB-NB in } \\
\text { \%-points }\end{array}$ \\
\hline \multicolumn{14}{|l|}{ Men } \\
\hline Austria & 16.4 & 49 & 81.2 & 81.0 & 81.0 & 78.5 & 73.7 & 71.5 & 4.8 & 3.4 & 9.0 & 11.6 & 5.6 \\
\hline Australia & 28.1 & $\ldots$ & 83.8 & 80.5 & $\ldots$ & 79.7 & 76.1 & $\ldots$ & 3.6 & 4.9 & 5.5 & $\ldots$ & 0.6 \\
\hline Belgium & 12.3 & 51 & 73.0 & 74.0 & 74.1 & 68.6 & 62.2 & 57.8 & 6.4 & 5.9 & 15.9 & 22.0 & 10.0 \\
\hline Canada & 20.3 & $\ldots$ & 82.0 & 83.2 & $\ldots$ & 75.5 & 75.8 & $\ldots$ & -0.3 & 7.9 & 8.8 & $\ldots$ & 0.9 \\
\hline Denmark & 8.4 & 49 & 84.6 & 80.2 & 77.6 & 80.7 & 73.4 & 70.2 & 7.4 & 4.5 & 8.5 & 9.5 & 4.0 \\
\hline France & 11.9 & 66 & 75.1 & 77.2 & 76.4 & 69.6 & 66.9 & 64.3 & 2.7 & 7.4 & 13.4 & 15.9 & 5.9 \\
\hline Germany & 15.1 & & 82.2 & 82.6 & $\ldots$ & 76.4 & 72.0 & $\ldots$ & 4.4 & 7.0 & 12.8 & $\ldots$ & 5.8 \\
\hline Netherlands & 12.2 & 76 & 85.8 & 79.9 & 79.1 & 83.4 & 73.9 & 72.4 & 9.5 & 2.8 & 7.6 & 8.5 & 4.8 \\
\hline Norway & 9.0 & 53 & 82.0 & 81.3 & 75.5 & 79.8 & 74.4 & 66.5 & 5.4 & 2.7 & 8.5 & 12.0 & 5.8 \\
\hline Sweden & 15.2 & 59 & 81.9 & 79.3 & 78.2 & 76.7 & 68.3 & 63.6 & 8.5 & 6.3 & 14.0 & 18.6 & 7.6 \\
\hline Switzerland & 27.2 & 33 & 87.6 & 88.9 & 87.8 & 85.4 & 83.9 & 80.1 & 1.5 & 2.5 & 5.6 & 8.8 & 3.1 \\
\hline United Kingdom & 13.7 & 63 & 81.9 & 83.2 & 80.9 & 75.8 & 76.9 & 73.8 & -1.1 & 7.5 & 7.6 & 8.9 & 0.1 \\
\hline United States & 16.7 & 89 & 77.4 & 86.0 & 86.3 & 70.5 & 79.1 & 79.0 & -8.6 & 8.6 & 8.0 & 8.5 & -0.6 \\
\hline Average & 15.9 & 59 & 81.4 & 81.3 & 79.7 & 77.0 & 73.6 & 69.9 & 3.4 & 5.5 & 9.6 & 12.4 & 4.1 \\
\hline \multicolumn{14}{|l|}{ Women } \\
\hline Austria & 18.1 & 43 & 70.7 & 62.0 & 55.5 & 68.1 & 57.0 & 49.7 & 11.1 & 3.7 & 8.0 & 10.3 & 4.3 \\
\hline Australia & 28.4 & $\ldots$ & 72.6 & 64.0 & $\ldots$ & 69.1 & 60.1 & $\ldots$ & 9.0 & 4.9 & 6.0 & $\ldots$ & 1.1 \\
\hline Belgium & 13.2 & 50 & 62.3 & 51.4 & 46.4 & 58.0 & 43.2 & 36.2 & 14.8 & 6.9 & 16.0 & 22.0 & 9.1 \\
\hline Canada & 21.6 & $\ldots$ & 75.6 & 69.7 & $\ldots$ & 71.2 & 63.7 & $\ldots$ & 7.5 & 5.8 & 8.6 & $\ldots$ & 2.8 \\
\hline Denmark & 9.7 & 51 & 78.3 & 66.8 & 60.7 & 75.1 & 60.9 & 54.5 & 14.2 & 4.2 & 8.9 & 10.3 & 4.8 \\
\hline France & 12.5 & 65 & 67.3 & 59.7 & 55.4 & 61.6 & 51.4 & 46.4 & 10.2 & 8.5 & 13.8 & 16.2 & 5.4 \\
\hline Germany & 16.0 & $\ldots$ & 72.9 & 62.3 & $\ldots$ & 68.0 & 54.5 & $\ldots$ & 13.5 & 6.6 & 12.5 & $\ldots$ & 5.9 \\
\hline Netherlands & 13.6 & 73 & 75.1 & 61.6 & 57.5 & 72.8 & 57.2 & 52.9 & 15.5 & 3.1 & 7.0 & 8.0 & 4.0 \\
\hline Norway & 9.7 & 59 & 77.1 & 72.3 & 68.1 & 75.4 & 68.3 & 63.4 & 7.1 & 2.2 & 5.5 & 7.0 & 3.3 \\
\hline Sweden & 17.4 & 57 & 78.6 & 67.6 & 63.7 & 73.7 & 58.3 & 52.0 & 15.4 & 6.2 & 13.7 & 18.4 & 7.5 \\
\hline Switzerland & 28.0 & 36 & 78.4 & 73.3 & 68.2 & 76.0 & 67.6 & 59.5 & 8.3 & 3.1 & 7.7 & 12.8 & 4.7 \\
\hline United Kingdom & 14.2 & 62 & 70.4 & 62.9 & 55.9 & 66.5 & 58.2 & 50.6 & 8.3 & 5.6 & 7.5 & 9.5 & 2.0 \\
\hline United States & 15.7 & 88 & 68.9 & 62.9 & 62.3 & 64.7 & 58.4 & 57.7 & 6.3 & 6.1 & 7.1 & 7.4 & 1.0 \\
\hline Average & 16.8 & 59 & 72.9 & 64.3 & 59.4 & 69.2 & 58.4 & 52.3 & 10.9 & 5.1 & 9.4 & 12.2 & 4.3 \\
\hline
\end{tabular}

Notes: "Lower-income" refers to all non-OECD countries plus Mexico and Turkey. Data for Australia refer to the average of Jan. 2008June 2009. For Canada, separate data for men and women were not available for the foreign-born from lower-income countries. The average refers to the unweighted average of all countries included in the table.

Source: European Union Labour Force Survey, except United States (Current Population Survey March Supplement), Canada (Labour Force Survey) and Australia (Labour Force Survey). 
DELSA/ELSA/WD/SEM(2011)12

\section{Box 1. Data and research on immigrants and their children in Austria}

In spite of Austria's large immigrant population, data and research on the integration of immigrants and their children are scarce. This is partly attributable to the fact that most administrative data and much of the research have been based on the concept of nationality, rather than place of birth. "Immigrants and their children" are thus viewed as persons with a foreign nationality. Foreigners are identified only by individual nationality in Austrian population statistics since 1981, and data on migration flows by nationality are only available since 1998.

The reliance on data on foreign nationals is a major shortcoming, in particular with respect to immigrants from lower-income countries who are more likely to take-up the host-country nationality, and in particular those who are better integrated. Statistics on the foreign population thus tend to overestimate the gaps in labour market outcomes between immigrants and the native-born (see OECD, 2011). Among the foreign-born in Austria, 36\% have Austrian nationality; among those from Turkey, this figure is $48 \%$. At the same time, among the native-born children with two immigrant parents, $30 \%$ do not have Austrian nationality.

The principle source for data and research which contains information on the respondent's place of birth is the Austrian Microcensus (which also forms the basis of the Austrian Labour Force Survey). It is also the main source of data that has been used in this report. Over the past few years, the labour force survey has been gradually adjusted to the needs of migration research. In 2004, the design of the Microcensus was overhauled. The sampling strategy was changed from census- to register-based sampling. Moreover, in addition to other changes, the survey was made continuous, as households are now interviewed in every week of the year and not just over a reference period of four weeks, as had been the case before. These significant changes - in particular the change in the reference period which has a strong impact due to the high seasonality of employment in Austria - marked a break in the data series and render comparisons with years prior to 2004 virtually impossible.

Another major shortcoming has been the lack of longitudinal data. In contrast to several other OECD countries, Austria has no major panel survey which identifies immigrants and/or their offspring. Partly due to this lack of data, research on the integration of immigrants and their children, especially of the quantitative kind, has been extremely limited to date.

There have been a number of recent initiatives which should help to tackle the significant deficit in data and research. In the first quarter of 2008, as in the other European OECD countries, the Austrian Labour Force Survey contained an ad-hoc module on immigrants and their children. Questions included the reason for migration, the origin of qualifications and information on the recognition of foreign qualifications. Information on the countries of birth of the respondents' parents is now regularly included in the Austrian Microcensus since 2008, thereby providing the possibility to identify children of immigrants born in Austria.

A potentially powerful tool for the analysis of immigrants' labour market integration is the so-called data warehouse of the Austrian Public Employment Service (AMS) which is gradually being developed further. It provides longitudinal information on the respondents' employment and unemployment histories, participation in labour market measures, as well as on wages and benefit receipt from 1987 onwards. In recent years, the warehouse has been extended and it is now possible to match AMS data with other administrative data from the social insurance system. A major shortcoming of the AMS data in the past has been the exclusive identification on the basis of nationality, since the AMS does not register the individual's country of birth. Recently, however, there has been an effort to proxy for the respondent's "migration background" by using available information on the respondent's current and previous nationality, as well as the nationality or previous nationality of the parent, for those who are co-insured. This latter information is only available since 2007. All of these data are only gradually becoming available and up to now, there has been no in-depth study of the labour market integration of immigrants using this information. Since 2010, information from the data warehouse can also be linked with data from the labour force survey. This should give a boost to research on labour market integration in the future.

4 Even research on the integration of foreigners has been limited. In contrast, there have been a number of studies which look at the impact of immigration on the labour market prospects of natives and its impact on economic growth (see e.g. Biffl, 2010b; Bock-Schappelwein et al., 2009; Hofer and Huber, 2001). 


\section{Box 1. Data and research on immigrants and their children in Austria (cont'd)}

Regarding the children of immigrants, the Ministry of Education and the Federal Ministry of Labour, Social Affairs and Consumer Protection have recently commissioned a panel survey among 5000 students at the age of 14 who are in the final year of lower secondary education. They will be surveyed about their school-to-work-transition at the ages of 15, 16 and 17, i.e. between 2011 and 2013. As children of immigrants are overrepresented in the target group, this survey should shed some more light on the difficulties which they encounter when entering the labour market, and possible solutions.

To overcome the current deficit in research on integration, the Vienna Science and Technology Fund has established a special programme for funding research on "ethnic origin, migration, inter-cultural mobility, integration and inter-cultural relationships". EUR 1.2 million were allocated in 2010 and an additional 2 million are available in the 2011 project call which has a special focus on the labour market.

Figure 1. Evolution of the employment/population ratio in Austria since 2004, by country of birth, aged 15-64

Men

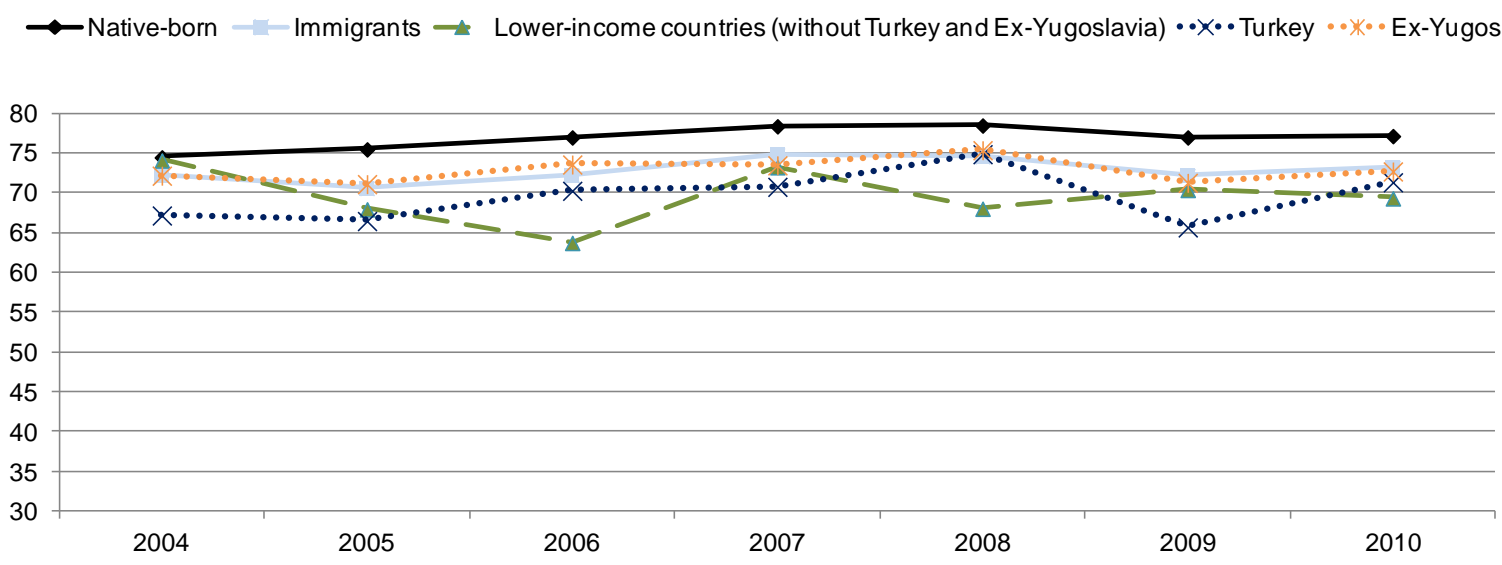

Women

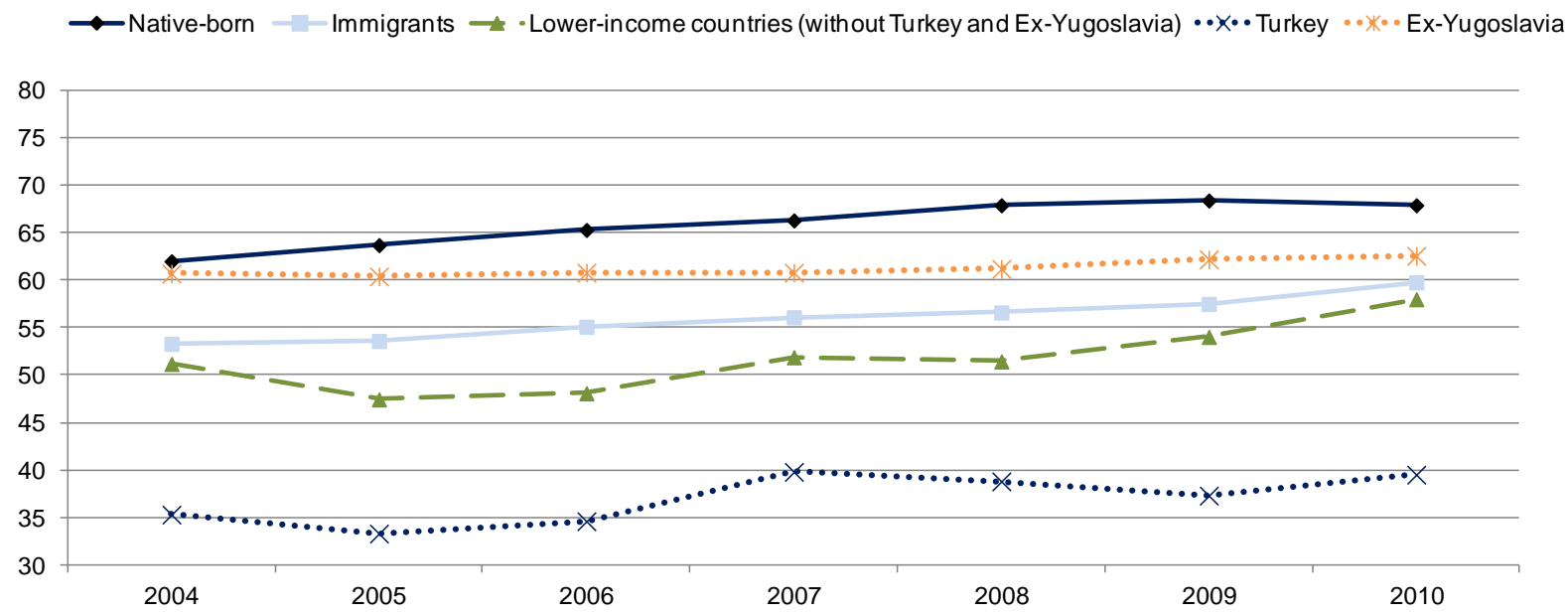

Source: 2004-2010: Austrian Microcensus (data provided by Statistics Austria). 2001: OECD Database on Immigrants and Expatriates in OECD countries (DIOC). 
DELSA/ELSA/WD/SEM(2011)12

Figure 2. Evolution of the unemployment rate in Austria since 2004, by country of birth, aged 15-64

Men

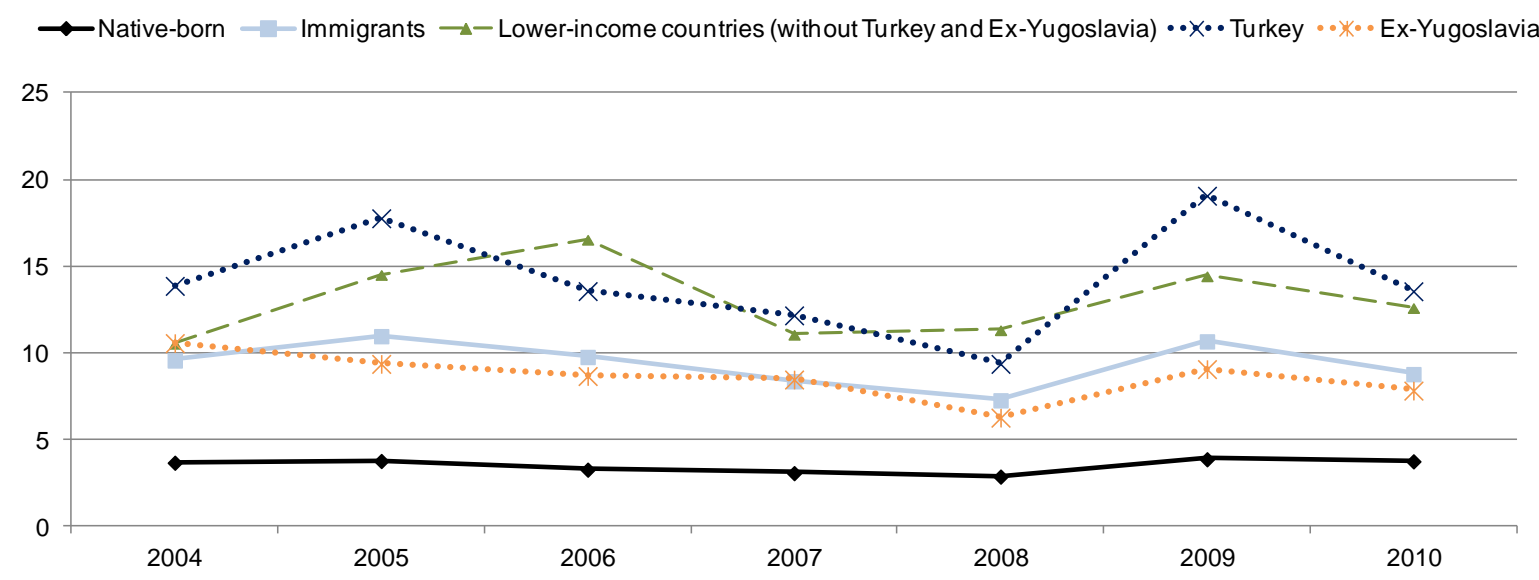

Women

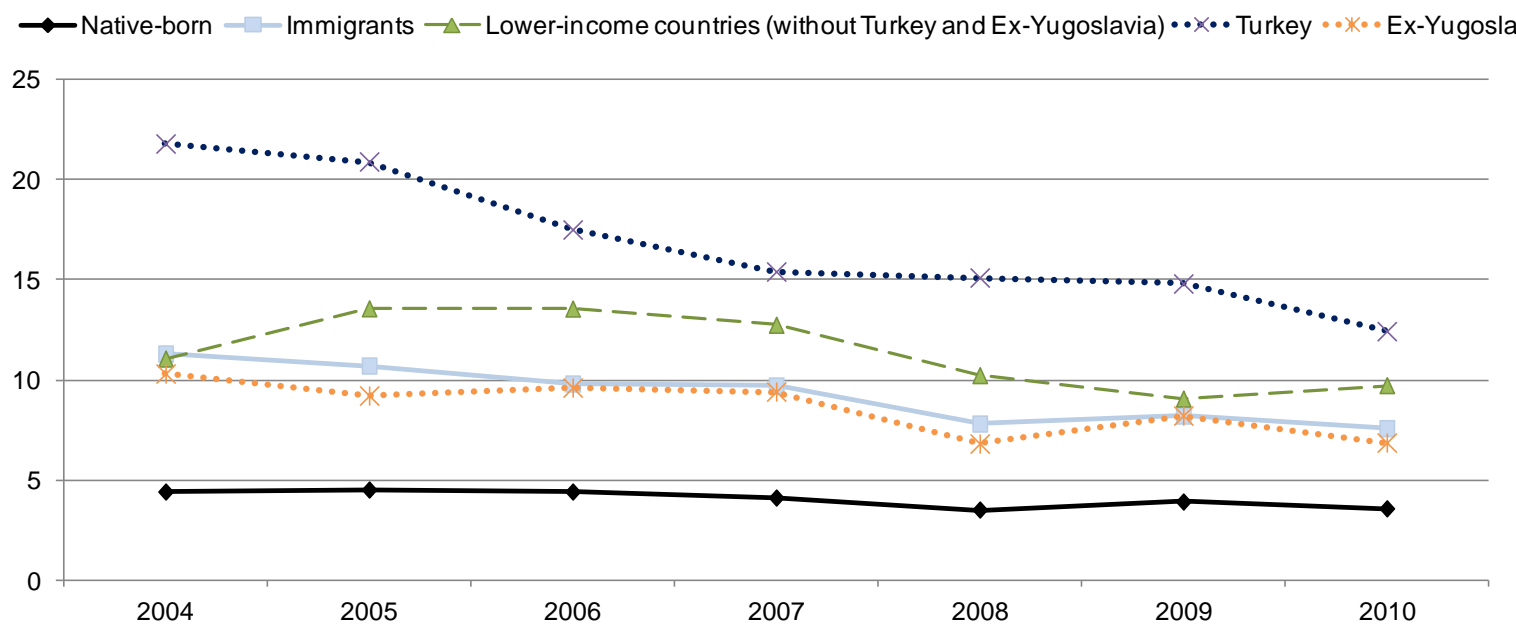

Source: See Figure 1.

9. Table A1 in the Annex further disaggregates the outcomes for immigrants by country of origin. It shows a large variation of outcomes by origin. Immigrants from the EU-15 and Switzerland generally outperform the native-born in the labour market. At the other end of the spectrum are immigrants from Turkey, for whom the outcomes are well below those of the native-born, for both genders. Outcomes are also unfavourable for immigrants from the non-EU countries of Eastern Europe (mainly Russia), from Asia and Africa, who nevertheless account for a relatively small part of the immigrant population.

10. The effect of the recent crisis is highly visible in the evolution of the unemployment rate of immigrant men, in particular those from Turkey (see Figure 2). Indeed, the unemployment of Turkish men seems to be particularly sensitive to overall labour market conditions. A one percentage- point change in the unemployment rate of native-born men is associated with a two percentage-point change for immigrants as a whole, and a 4-5 percentage- point change in the unemployment rate of men from Turkey. 
11. The pattern is again different for women. Here, one observes a trend decline in the unemployment rate of immigrant women since 2004, both in absolute terms and relative to the native-born. The effect is particularly strong for women from Turkey, who were also apparently not negatively affected by the crisis. The slight trend improvement in employment observed above was thus mainly driven by a decline in unemployment and not by an increase in labour market participation.

\section{Children of immigrants}

12. Among the 15-29 year- old population in Austria, one fifth has two foreign-born parents. About $6 \%$ were born in Austria to foreign-born parents. This group is growing rapidly; it already accounts for 15\% among those aged between 6 and 14 (see Table A2 in the Annex). Most of the children of immigrants $-78 \%$ - have parents from lower-income countries, notably from the former Yugoslavia and from Turkey which together account for $60 \%$ of all native-born children of immigrants.

Figure 3. Employment rates of the native-born children of immigrants and the children of natives, selected OECD countries, aged 20-29 and not in education, around 2007

Men

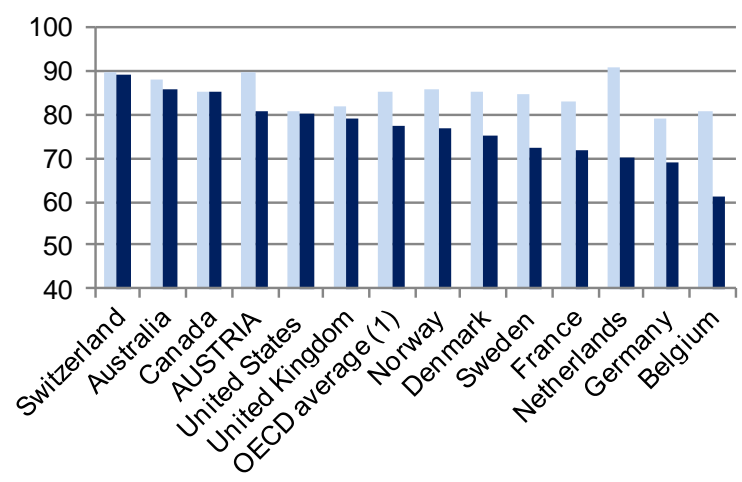

Children of native-born
Women

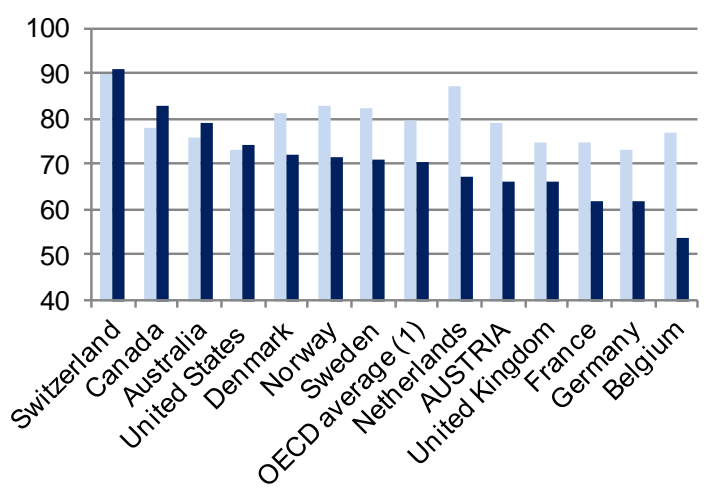

Native-born children of immigrants

Note: Data for France exclude native-born children of those foreign-born parents who had French nationality at birth. Adjustments were also made for Australia, Denmark and Switzerland (see OECD, 2010a). 1: The OECD average refers to the unweighted average of the countries included in the figures.

Source: Adapted from OECD (2010a).

13. In international comparison, young people in Austria enjoy good overall labour market outcomes. Among those who are not in education, young men (aged 20 to 29) without a migration background have an employment rate of about 90\%, one of the highest in the OECD (see Figure 3). The native-born sons of immigrants have, likewise, rather favourable outcomes in international comparison, with an employment rate of roughly $80 \%$. However, compared with most other countries that record high employment rates, namely Switzerland, Australia and Canada, native-born sons of immigrants in Austria face rather large gaps in their employment rate compared with the sons of native-born. The situation is less favourable with respect to the employment rates of young native-born women with immigrant parents. Here, Austria ranks in the middle range of the comparison group, and the gaps are larger than the OECD average.

14. Although employment rates suggest that immigrant offspring in Austria master the school-towork transition rather well, this masks the fact that a rather large portion of the youth population with an immigrant background is both low-educated and neither in employment nor education or training (low- 
educated NEET). $14 \%$ of native-born female offspring of immigrants in Austria belong to this population group (see Figure 4). In the comparison group, only Belgium records a higher share. These figures have to be seen in perspective with the relatively low incidence of low-educated NEET among the female offspring of native-born, among whom only $2 \%$ belong to the "population at risk", suggesting that this problem is largely related to immigrant background. Although young men with immigrant parents fare slightly better, they are still more than four times as likely to find themselves in this group with particularly poor labour market prospects.

\section{Figure 4. "Population at risk" among native-born children of immigrants and the children of native-born, by gender, aged 20-29, around 2007}

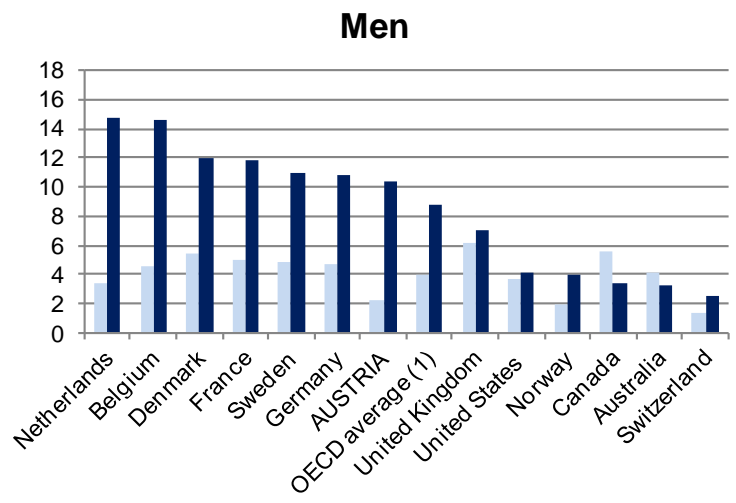

Children of native-born

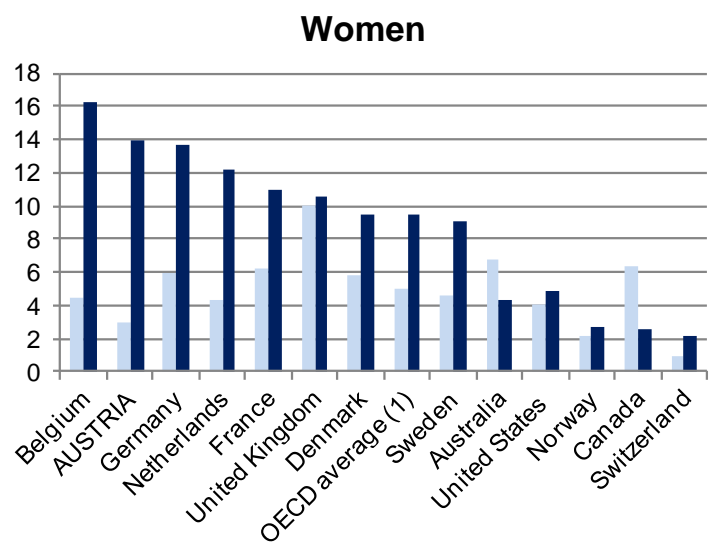

Native-born children of immigrants

Note: The "population at risk" is defined as being low-educated and not in employment, education or training. 1: The OECD average refers to the unweighted average of the countries included in the figure. See also figure 3.

Source: Adapted from OECD (2010a).

15. To summarise, at first glance the labour market outcomes of immigrants - in particular those from lower-income countries and from Turkey - and their children are significantly less favourable than those of persons without a migration background. ${ }^{5}$ This holds in particular with respect to the incidence of unemployment and, for youth, the low-educated NEET. Women seem to be at a greater disadvantage than men, and this holds also in international comparison.

\section{Regional differences}

16. The immigrant population is strongly concentrated in Vienna. $42 \%$ of all immigrants live in Vienna compared with only $16 \%$ of the native-born. The concentration is even greater for the children of immigrants. This uneven geographic distribution has an important impact on aggregate outcomes, since the labour market conditions in Vienna are less favourable than in the remainder of Austria (see Table A3.1 and A3.2 in the Annex). Over the past few years, unemployment has been nearly twice as high in Vienna as elsewhere in the country, and national employment rates are seven percentage points higher for men and two percentage points higher for women than in Vienna. Accounting for the uneven distribution tends to

5 The term "migration background" is a commonly-used term in Austria to distinguish immigrants and their children on the one side from the offspring of the native-born. Although, as will be explained in more detail in Section V, one should be careful in examining the integration of immigrants and that of their offspring in the same terms, since the issues involved differ, the phrase "migration background" is nonetheless occasionally used in this document for the sake of convenience. 
lower the differences between immigrants and the native-born, as well as for their respective children, substantially. However, one observes that in general, immigrants and their children, when compared with their native peers, fare better in Vienna than elsewhere. The exception is the female offspring of immigrants, for whom the unemployment rate and the incidence of low-educated NEET are particularly high in Vienna.

\section{The framework for integration}

17. This section discusses the overall context for integration policy in Austria. It starts with an historical overview of the evolution of immigration to Austria, to explain how the main current groups of immigrants and their children have emerged. Following this, the evolution and current structure of integration policy is presented, along with the Austrian labour market setting. This section concludes with a presentation of the main stakeholders for integration in Austria.

\section{The evolution of immigration to Austria and the main immigrant groups}

\section{From the Habsburg Empire to the early 1950s}

18. Austria is a country with a long-standing history of immigration, emigration and transit migration that have essentially followed the pattern of inflows from the East and outflows towards the West. ${ }^{6}$

19. In 1848, when Austria was in a double monarchy with Hungary, citizens of the Austro-Hungarian Empire were granted the right of free movement within its borders, which led numerous Czech-, Slovak-, Polish- and Serbo-Croatian speaking migrants from the outskirts of the empire to move to its core cities Budapest, Prague and Vienna, as well as to the industrialising regions of Styria and Vorarlberg. To date, Bosnia and Herzegovina, Serbia, Poland, the Czech Republic, Hungary and Croatia are still among the most important source countries of migration to Austria (see Table 2).

20. In 1919, following the First World War, which had brought about the dissolution of the AustroHungarian Empire, the criteria for Austrian nationality were redefined. Residents who did not belong to the ethnic majorities of the monarchy's non-German-speaking successor countries and who could be considered German by "race and language" were offered citizenship (see Bauböck, 1996). As nationalist tensions in Austria grew in the interwar period, this definition of nationality offered a means to expel members of minorities from the territory of the Austrian republic. At this point, many migrants and their offspring returned to their regions of origin which had emerged from the war as separate countries. Between 1918 and 1948, about 160000 Czechs and Slovaks, who had once represented the largest linguistic minority in the Austro-Hungarian empire in the land of the new Austrian republic, were repatriated (see Bauböck, 1996). Remaining members of linguistic minorities were pressured to assimilate. Their children were absorbed into Austrian society without further concern about actual integration difficulties. ${ }^{7}$

21. In the post-World War II period, migration to Austria has been based on two main pillars. The first is the so-called "guestworker" migration from Turkey and the former Yugoslavia, as well as subsequent family migration from these countries. Humanitarian migration, mainly from Central and South-Eastern Europe, represented the second pillar and concerned Austria as a destination country, but also as a neutral main country of transit between the two blocks of the cold-war era.

6 For overviews of the history of migration from and to Austria, see Bauböck (1996), Bauer (2008) and Fassmann and Münz (1995).

7 Slavic family names are still widespread in Austria and a reminder of this early phase of immigration. However, their spelling has often been "Germanised" as a result of efforts to assimilate. 
DELSA/ELSA/WD/SEM(2011)12

\section{"Guestworker" migration to Austria and subsequent family migration}

22. Like most other Western European countries, Austria experienced sustained economic growth in the post-war period, but labour shortages were not visible until the late 1950s. This was partly due to deficits in the modernisation of the Austrian industry, as well as to the integration of half a million displaced persons who had arrived in the aftermath of the World War II and represented a sizeable pool of workers (see Bauböck, 1988). During the early post-war years, many Austrians emigrated to Switzerland and Western Germany to benefit from higher wages and better working conditions. The recruitment of guestworkers in Austria hence set in with some delay compared with other European countries, notably with Austria's neighbours Germany and Switzerland.

23. The policy framework for the recruitment of labour migrants essentially emerged as a compromise between the social partners who have played a key role in shaping labour migration policy during the entire post-War period until today. They were split into advocates of recruitment on the side of the employers and opponents on the side of the trade unions and the chambers of labour. In the summer of 1961, the social partners agreed upon a first modest numerical limit on the number of foreigners to be recruited for work in the construction sector. However, with no recruitment agency yet in place, the actual number admitted remained below the numerical limit. At the end of the same year, the social partners established an official agreement for the large-scale recruitment of guestworkers (the so-called Raab-Olah Agreement). It stipulated conditions for their admission to the Austrian labour market and determined a first yearly numerical limit of 47000 foreign workers. This corresponded to $2 \%$ of total employment at that time. For foreign workers coming under this numerical limit, the usually required individual labour market test was abandoned. The trade unions agreed under the condition that guestworker permits would be limited to 12 months and that foreign workers be employed under the same conditions as natives, but laid off preferentially in cases of economic pressure. ${ }^{8}$ The Austrian guestworker scheme thus envisioned a system of rotation that would permit the hiring and replacement of foreign workers at short notice in response to labour market needs. From the start, this concept was undermined by the fact that permits were renewable and allowed guestworkers to stay in Austria for more than a year. Many employers took advantage of this possibility to request renewal and to keep the workers with whom they were familiar.

24. In its initial phase, recruitment got under way rather slowly before it intensified in the mid-1960s. In the first years following the Raab-Olah Agreement of 1961, inflows remained far below the average yearly numerical limits of 37000 permissions, and a bilateral recruitment agreement with Spain from 1962 had no notable impact. Spanish and Italian guestworkers were more attracted to countries such as Switzerland and Germany, which offered higher wages and had already well-established recruitment systems. Moreover, the Austrian economy was expanding at a rather moderate rate (see Bauböck, 1988). Hence, the share of foreigners in the total Austrian population remained modest at about $1.5 \%$ throughout the early 1960s.

25. Recruitment only started to soar after bilateral recruitment agreements were signed with Turkey (1964) and the former Yugoslavia (1966) and recruitment agencies were established in Belgrade and Istanbul. The share of foreign workers in total employment increased sharply from 1\% in 1964 to almost $9 \%$ in 1973. In that year, the absolute number of foreign workers peaked at 227000 . Over the course of a few years, Turkey and Yugoslavia had become the two major origin countries for migration to Austria. Today, immigrants who were born in Turkey or the former Yugoslavia make up 6\% of the overall Austrian population and account for more than $40 \%$ of the foreign-born (see Table 2).

8 This provision remained formally in place until its recent abolition under the new immigration law which entered into force on 1 July 2011 (see below). 
DELSA/ELSA/WD/SEM(2011)12

Table 2. Composition of the immigrant population by main countries of birth, as a percentage of the total foreign-born population

\begin{tabular}{|ll|}
\hline & $\mathbf{2 0 0 9}$ \\
\hline Germany & $15 \%$ \\
Serbia and Montenegro & $15 \%$ \\
Turkey & $12 \%$ \\
Bosnia and Herzegovina & $10 \%$ \\
Romania & $5 \%$ \\
Poland & $4 \%$ \\
Czech Republic & $4 \%$ \\
Hungary & $3 \%$ \\
Croatia & $3 \%$ \\
Russian Federation & $2 \%$ \\
\hline \hline Other countries & $26 \%$ \\
\hline
\end{tabular}

Source: OECD International Migration Database.

26. The importance of "guestworker" migration is even more visible among the native-born children of immigrants - about $75 \%$ of immigrant children aged 20-34 have parents from former Yugoslavia or from Turkey. Box 2 provides an overview of the labour market outcomes of immigrants from these countries in international comparison.

27. In 1973, at the peak of guestworker recruitment, Austria was hit by the first oil price shock, which marked a turning point in its labour migration policy. Official recruitment came to a halt and labour market access was restricted. A new foreigners' employment law came into effect in 1976 that formalised the main principles of guestworker recruitment which had been applied in practice since $1961 .{ }^{9}$ Key elements were the yearly definition of numerical limits on recruitment, the priority of Austrian workers in hiring and the preferential laying off of foreigners (see Bauböck, 1988).

28. Many labour migrants returned to their countries of origin over the following years and the number of registered foreign workers decreased by almost $40 \%$ between 1974 and $1984 .{ }^{10}$ Others, however, found it too risky to leave at this point when re-admission to Austria had become unlikely. Instead, these immigrants - in particular those from Turkey - settled and subsequently brought over family from their origin countries. ${ }^{11}$ Already before the recruitment ban came into effect, this development had been enforced by the fact that employers had started to renew existing work contracts, as well as to recruit family members and friends of already employed foreigners. This practice had contributed to undermining the "rotation system" of strictly temporary migration that had been envisioned by the social partners. Until the mid 1980s, family migration largely compensated for the return migration of guestworkers (see Lebhart and Marik-Lebeck, 2007). The share of foreigners in the Austrian population thus remained steady at roughly $4 \%$ until 1986 , while employment of foreigners decreased.

9 In spite of the end of official recruitment in 1973, the "guestworker" system remained in place until 1992.

10 This decline is partly due to naturalisation rates of $3 \%$ of the total foreign population on average per year. However, among these naturalisations, immigrants from Yugoslavia accounted for a rather modest share of roughly $17 \%$, and there were few naturalisations of Turkish nationals at that time. About half the naturalisations concerned immigrants from Germany and Eastern Europe.

11 Indeed, there is some evidence that return migration among Yugoslavians was much more pronounced than among the Turks, while the reverse was observed for family migration. As a result, the Turkish population grew more strongly between 1971 and 1981 than the Yugoslav population (see Neyer, 1985). It is unclear to which extent this differential migration pattern has contributed to the rather strong differences that are observed in terms of labour market integration for these two groups (see Box 2). 


\section{Box 2. Immigrants from the former Yugoslavia and Turkey and their labour market integration in Austria}

Immigrants from the various successor countries of the former Yugoslavia and Turkey together account for more than $40 \%$ of the immigrant population in Austria, and almost $80 \%$ of the immigrants from lower-income countries.

With the recent update of the OECD database on immigrants and expatriates in OECD countries (DIOC-2005), a comparative overview of the labour market outcomes of immigrants by origin country is possible for those OECD countries where they account for a sizeable population group. The table below provides such an overview for selected OECD countries around 2005. Compared with other OECD countries, immigrants from the former Yugoslavia have relatively high employment rates in Austria. In contrast, immigrant women from Turkey fare less well in Austria than in the labour markets of other OECD countries. In addition, for both origin groups and both genders, differences in unemployment tend to be relatively large in Austria.

Labour force characteristics of immigrants from the former Yugoslavia and Turkey in Austria and other OECD host countries, aged 15-64, around 2005

\begin{tabular}{|c|c|c|c|c|c|c|c|c|c|c|c|c|}
\hline & \multicolumn{3}{|c|}{ Employment rates (ER) in \% } & \multicolumn{3}{|c|}{$\begin{array}{l}\text { Percentage point difference in the ER } \\
\text { compared with the native-born } \\
\text { (native-born minus other) }\end{array}$} & \multicolumn{3}{|c|}{ Unemployment rates (UR) in \% } & \multicolumn{3}{|c|}{$\begin{array}{l}\text { Percentage point difference in the UR } \\
\text { compared with the native-born } \\
\text { (native-born minus other) }\end{array}$} \\
\hline & Ex-Yugoslavia & Turkey & Foreign-born & Ex-Yugoslavia & Turkey & Foreign-born & Ex-Yugoslavia & Turkey & Foreign-born & Ex-Yugoslavia & Turkey & Foreign-born \\
\hline Australia & 63 & 51 & 70 & 13 & 25 & 5 & 6 & 11 & 6 & -1 & -6 & -1 \\
\hline Austria & 67 & 53 & 63 & 4 & 18 & 8 & 10 & 17 & 10 & -6 & -13 & -6 \\
\hline Belgium & 45 & 36 & 50 & 18 & 27 & 12 & & 28 & 17 & & -21 & -10 \\
\hline Canada & 75 & 61 & 72 & 0 & 14 & 3 & 6 & 11 & 7 & 0 & -5 & -1 \\
\hline Denmark & 58 & 61 & 63 & 23 & 20 & 18 & 7 & 12 & 7 & -5 & -10 & -5 \\
\hline France & 52 & 46 & 57 & 13 & 19 & 8 & 23 & 27 & 18 & -13 & -17 & -8 \\
\hline Germany & 59 & 51 & 61 & 11 & 19 & 9 & 15 & 20 & 15 & -6 & -12 & -6 \\
\hline Netherlands & 58 & 54 & 60 & 17 & 21 & 15 & 13 & 11 & 11 & -8 & -7 & -6 \\
\hline Norway & 65 & 52 & 70 & 27 & 41 & 22 & & .. & .. & .. & .. & .. \\
\hline Switzerland & 68 & 65 & 74 & 14 & 17 & 8 & 11 & 15 & 8 & -8 & -12 & -5 \\
\hline United States & 74 & 70 & 72 & -2 & 2 & 0 & 7 & 7 & 7 & 0 & 1 & 1 \\
\hline Average $^{1}$ & 62 & 54 & 65 & 13 & 20 & 10 & 11 & 16 & 11 & -5 & -10 & -5 \\
\hline Men & & & & & & & & & & & & \\
\hline Australia & 71 & 65 & 80 & 11 & 17 & 2 & 6 & 10 & 6 & -1 & -5 & -1 \\
\hline Austria & 73 & 69 & 73 & 5 & 9 & 5 & 9 & 15 & 10 & -6 & -11 & -6 \\
\hline Belgium & 57 & 54 & 61 & 13 & 15 & 8 & .. & .. & 16 & .. & .. & -9 \\
\hline Canada & 81 & 74 & 80 & -2 & 5 & -1 & 5 & $\ddot{9}$ & 6 & 1 & -3 & 0 \\
\hline Denmark & 64 & 68 & 67 & 21 & 16 & 17 & 6 & 10 & 2 & -4 & -8 & -5 \\
\hline France & 57 & 65 & 65 & 13 & 5 & 5 & 21 & 21 & 15 & -12 & -12 & -6 \\
\hline Germany & 67 & 65 & 69 & 8 & 10 & 6 & 16 & 20 & 9 & -8 & -11 & -7 \\
\hline Netherlands & 65 & 70 & 69 & 18 & 12 & 13 & 13 & 10 & 4 & -9 & -6 & -7 \\
\hline Norway & 66 & 59 & 71 & 26 & 33 & 21 & .. & .. & .. & .. & .. & \\
\hline Switzerland & 77 & 70 & 83 & 11 & 18 & 5 & 8 & 16 & 7 & -6 & -13 & -5 \\
\hline United States & 81 & 81 & 82 & -5 & -5 & -7 & 6 & 6 & 6 & 2 & 2 & 2 \\
\hline Average $^{1}$ & 69 & 67 & 73 & 11 & 12 & 7 & 10 & 13 & 8 & -5 & -7 & -4 \\
\hline Women & & & & & & & & & & & & \\
\hline Australia & 54 & 36 & 62 & 16 & 34 & 8 & 6 & 13 & 7 & -2 & -8 & -2 \\
\hline Austria & 61 & 34 & 54 & 3 & 30 & 10 & 10 & 20 & 10 & -5 & -16 & -6 \\
\hline Belgium & 31 & 18 & 40 & 25 & 38 & 16 & .. & .. & 18 & .. & .. & -10 \\
\hline Canada & 68 & 46 & 65 & 3 & 25 & 6 & 7 & 15 & 8 & -1 & -8 & -2 \\
\hline Denmark & 52 & 51 & 58 & 24 & 25 & 18 & 7 & 9 & 15 & -4 & -6 & -13 \\
\hline France & 47 & 24 & 49 & 14 & 36 & 12 & 26 & 42 & 21 & -14 & -31 & -10 \\
\hline Germany & 51 & 35 & 52 & 13 & 29 & 13 & 15 & 13 & 22 & -6 & -4 & -13 \\
\hline Netherlands & 51 & 36 & 51 & 17 & 32 & 16 & 11 & 12 & 14 & -6 & -8 & -10 \\
\hline Norway & 63 & 43 & 69 & 29 & 50 & 24 & & .. & .. & .. & .. & .. \\
\hline Switzerland & 58 & 59 & 65 & 17 & 16 & 10 & 13 & 13 & 9 & -10 & -10 & -6 \\
\hline United States & 67 & 57 & 61 & 1 & 11 & 8 & 8 & 8 & 8 & -1 & -1 & -1 \\
\hline Average $^{1}$ & 55 & 40 & 57 & 15 & 30 & 13 & 11 & 16 & 13 & -6 & -10 & -7 \\
\hline
\end{tabular}

Notes: Persons with unknown gender and place of birth are excluded. Former Yugoslavia includes all successor countries except Slovenia. 1: The average includes all countries for which data are presented in the table.

Source: OECD Database on Immigrants in OECD countries (DIOC 2005).

29. Under the guestworker scheme, work permits were linked to a specific employer and the right to free labour movement within Austria could only be obtained through an exemption certificate (Befreiungsschein) that was granted after eight years of almost uninterrupted employment in Austria or to spouses of Austrian citizens. Although originally tailored to shield the Austrian labour market from new labour migrants, this rigid regulation hampered the labour market integration of family members who were already residing in Austria, since eight years of uninterrupted employment were difficult to achieve, 
especially for women with children. Throughout the 1980s, $15 \%$ of foreigners, on average, held an exemption certificate (Biffl, 1990). ${ }^{12}$

\section{Humanitarian migration}

30. The second major source of post-war immigration to Austria was migration on humanitarian grounds. Over the past three decades, Austria has been a major recipient of asylum seekers, and recorded roughly 480000 inflows between 1980 and 2009. This corresponds to almost 60 asylum seekers per thousand inhabitants, a figure that has only been topped by Sweden and Switzerland during that same period. Austria's central role with respect to humanitarian migration flows stems from its distinct geographical position between the two former blocs of the cold war era. It offered humanitarian migrants a first resort after the fall of the Iron Curtain, when new opportunities for migration from East to West opened up. Austria's role as a main recipient country of humanitarian migration was also shaped by the dissolution of the former Yugoslavia with which it shared frontiers, as well as strong historical ties. Since the 1970s, Austria moreover received smaller inflows of asylum seekers from Chile, Argentina, Uganda, Iran and Afghanistan.

31. Until the early 1980s, inflows of humanitarian migrants to Austria had been predominantly temporary, with Austria being a transit zone for migrants from Eastern Europe rather than an actual destination country. ${ }^{13}$ In the years immediately succeeding World War II it hosted close to one million displaced persons and Jewish refugees, as well as ethnic Germans from Central and Eastern Europe (see Bauböck, 1988). The majority left after several months, but between 300000 and 500000 ethnic Germans settled permanently. Austria experienced two further waves of humanitarian migration in 1956 and 1968, when uprisings against the Soviet occupation caused political turmoil in Hungary and the former Czechoslovakia. Only a small number of these migrants settled permanently in Austria.

32. Over the 1980s and 1990s, Austria shifted from a transit to a reception country, as humanitarian migration became more permanent in nature. This trend essentially started with a wave of humanitarian migration from Poland in 1981/1982, during which 33000 out of roughly 120000 migrants requested asylum. Around 18000 of these requests were successful (see Biffl, 2010a). In the following years, the number of asylum seekers who arrived in Austria rose sharply when the Iron Curtain fell and communist regimes in Eastern Europe dissolved. The number of asylum requests peaked at 27300 in the year 1990, when a wave of asylum seekers arrived from Romania. These high inflows sparked xenophobic fears in the Austrian population, as well as political consequences in the form of a more restrictive asylum law that came into effect in 1992.

33. The new law of 1992 established the option of "exceptional treatment" of immigrants who did not come from countries with severe human rights violations or for persons who had crossed a third country that could be considered safe before reaching Austria. Migrants from these groups could be denied asylum under an accelerated procedure, even before they filed a request. They were either sent back to their home countries or relegated to apply for asylum in the safe third country through which they had passed. As a consequence, asylum requests dropped significantly, to around 5000 in both 1993 and 1994. Whereas the acceptance rate of asylum requests had amounted to $90 \%$ in the 1970 s and roughly $50 \%$ in the mid 1980s, it dropped sharply to a low point of 7\% in 1993 (see Fassmann and Münz, 1995). In 2009, 19\% of asylum requests were accepted.

12 At the same time, some $75 \%$ of the foreign population in Switzerland held a permanent residence permit (see Bauböck, 1988).

${ }^{13}$ A major group to transit Austria were Jewish emigrants from the Soviet Union. 250000 to 300000 stayed temporarily in Austria between 1973 and 1989, before moving to the United States or Israel (see Bauböck, 1996). 
34. While the number of formal asylum seekers was reduced significantly, Austria continued to receive around 100000 humanitarian migrants between 1992 and 1995 who came from the war zones of the former Yugoslavia. The majority (about 90 000) came from Bosnia and Herzegovina and did not enter through the asylum channel but were directly granted temporary protection as "de-facto-refugees". As the conflict continued, many Bosnians were granted residence permits and labour market access, and few actually returned to Bosnia (see Biffl, 1999). ${ }^{14}$ Bosnians who arrived between 1992 and 1995 still make up $40 \%$ of the overall 145000 immigrants from Bosnia living in Austria today, who represent the fourth largest group of foreign-born (see Table 2). In the late 1990s, the number of asylum requests started to rise again, trigged by asylum seeking of Albanian Kosovars who fled the ethnic conflicts in Kosovo.

35. Over time, the source countries of humanitarian migration to Austria have diversified, although a significant proportion of asylum seekers continue to come from European countries. Over most of the 1980s, asylum seekers to Austria came almost exclusively from geographically close countries behind the Iron Curtain, namely the former Czechoslovakia, Hungary, Poland, Romania and the former Yugoslavia. Their total share among all asylum seekers remained at 80 to $90 \%$ throughout most of the decade. A diversification of humanitarian inflows started in the late 1980s and early 1990s when Austria started to record increasing asylum requests from Afghanistan, Iraq, Iran and India, as well as from Turkey. Over the past decade, there has also been a rising number of asylum requests of Russian nationals, who have recently replaced Afghans as the largest group of new asylum seekers. Nigeria and Georgia have also become major source countries in recent years. While Serbians still accounted for $15 \%$ of asylum seekers in the beginning of the past decade, their share has since dropped to roughly $8 \%$ in 2010.

36. The annual number of asylum requests declined continuously between 2002 and 2007, from 39 400 to 12000 and has remained below 16000 since. The decrease is partly attributable to EU enlargement which pushed the external EU border from Austria to the East. Indeed, part of the asylum seekers who previously demanded asylum in Austria now demand it in the new EU member countries (see Biffl, 2006).

\section{The fall of the Iron Curtain and the arrival of new immigrant groups}

37. As a consequence of the increasing humanitarian migration from Eastern Europe, inflows to Austria started to accelerate in the second half of the 1980s. Between 1986 and 1993, the share of the foreign population doubled from 4 to $8 \%$ and net migration peaked at 84700 in 1991, adding more than $1 \%$ to the Austrian population. This period was marked by an economic boom in Austria during which real annual GDP growth peaked at $4.5 \%$ in 1990, as the Austrian economy benefitted strongly from the fall of the Iron Curtain. The labour market experienced a significant growth in employment. At the same time, however, the labour market became more competitive and unemployment increased both for foreigners and Austrian nationals, reaching 8 and 5\%, respectively, in 1990 (see Biffl, 1991, for a comprehensive discussion).

38. Until the early 1990s, the employment rate for both foreign men and women was higher than for their Austrian counterparts (see Deutsch et al., 2010). In parallel with the high inflows, total unemployment started to grow, and foreign nationals experienced an over-proportional increase. Indeed, as Figure 5 shows, whereas (net) migration ${ }^{15}$ used to be procyclical in the early years, this has no longer been the case since the mid-1980s, and migration has shown a rather countercyclical pattern for the most part. ${ }^{16}$

14 For convenience, "Bosnia" is used as a shorthand for Bosnia and Herzegovina.

15 Until 1996, data on migration are only available for net migration.

16 Over the past 20 years, there has been no discernible correlation between the development of net migration and unemployment of Austrian nationals. 
39. Policy reacted to these developments in two ways. First, already in 1990, a "federal numerical limit" was introduced which capped the number of new work permits per year to limit the share of foreign workers in the total workforce to less than $10 \% .{ }^{17}$ Once this figure is reached, new work permits can only be granted to an additional $1 \%$ of the workforce to certain groups of foreign nationals determined in an ordinance by the Minister of Employment (see Nowotny, 2007 for more details). Until July 2011, there have been additional numerical limits for each federal state (Bundesland) in place. Once these were reached, the work permit procedure was tightened in the respective federal state. The state-specific limits were, in the early years, in the aggregate well below the federal limit, and thus occasionally tested, albeit this did not occur with the federal limit (see Biffl, 1992). The overall system was thus rather complex. ${ }^{18}$

Figure 5. Net migration and unemployment of nationals and foreigners in Austria since 1977

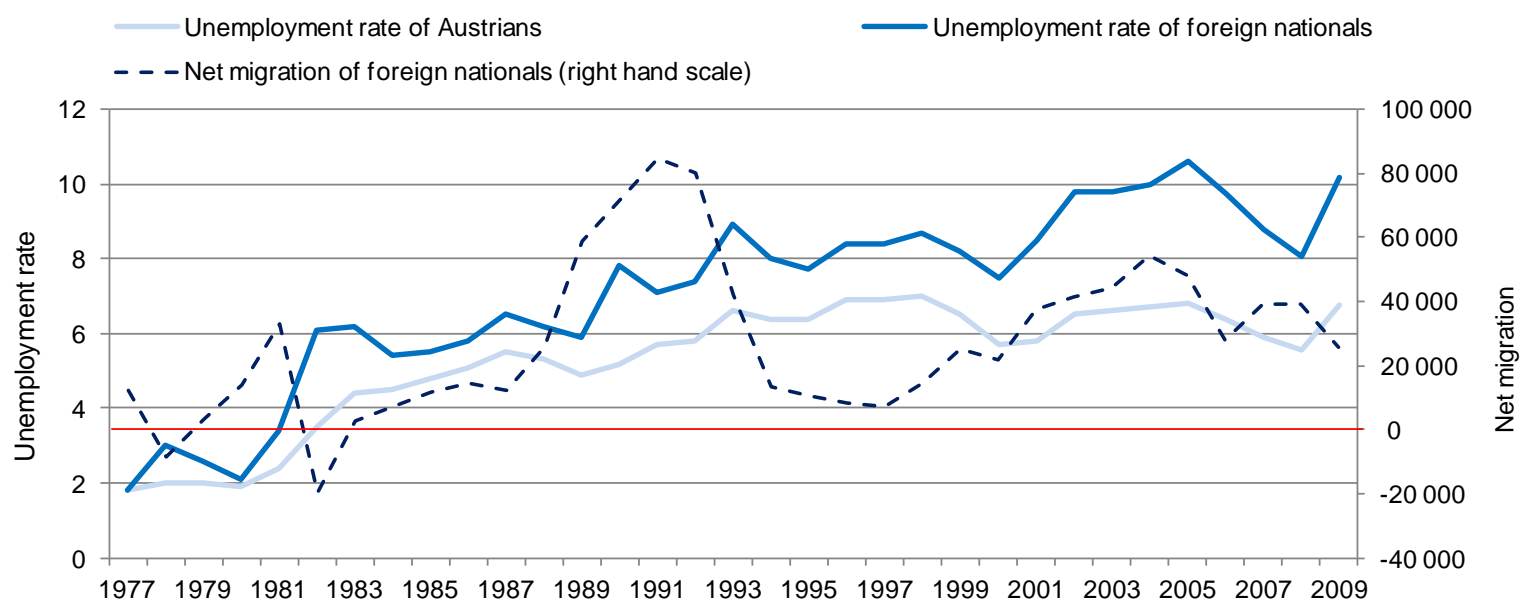

Note: There has been a break in the series for the unemployment rates for nationals and foreigners in 2008 due to a revision of the national unemployment register.

Source: Unemployment rates (national definition) provided by the Austrian Public Employment Service; data on inflows provided by Statistics Austria.

40. A second reaction followed in 1993, when a "settlement quota" system was introduced to restrict new immigration. ${ }^{19}$ This system introduced numerical limits, on an annual basis, for a number of migrant categories, notably for family migration of non-EU nationals. ${ }^{20}$ As for the "federal numerical limit", these are further broken down for each federal state. As a consequence, the actual impact varied considerably. In

17 In 1994, this number was further reduced to $8 \%$. At the same time, nationals from the EU-15 have been excluded from the count. On 1 May 2011, nationals from the EU-8 have also been excluded, and the limit lowered to 7\% of the workforce.

18 In parallel, in 1990, controls to prevent illegal employment of irregular migrants were enforced, along with a legalisation campaign that granted a work permit without a labour market test to foreigners who held a valid residence permit. Another innovation was that, after twelve months of legal employment in Austria, most migrant workers could get a renewable work permit (Arbeitserlaubnis) which granted them full labour market access for two years in the Austrian state where they had been employed with a work permit before.

19 In addition, also in 1993, a requirement for employers requesting a work permit for an immigrant was introduced which stipulated that the former has to declare that he or she did not fire or refuse employment to an older worker (above 50 years old) during the last six months for a similar post. This requirement is still formally in force.

20 The terms "federal numerical limit" and "settlement quota" are rather confusing, as the former essentially relates to a quota (i.e. the share of foreigners in the workforce) and the latter to a numerical limit. 
some federal states, prospective family migrants had to wait for more than five years before they would get allocated a place under the settlement quota and could migrate to Austria. With the introduction of the EU directive on family migration which was implemented in a comprehensive reform of the Alien's Act in 005 , the maximum waiting period for the immigration of family migrants under the "settlement quota" has been limited to three years. ${ }^{21}$

41. Those family migrants who managed to acquire a permit under the "settlement quota" system furthermore found themselves barred from the labour market for the first five years of residence, except if they passed a labour market test (see Section III below). After 2005, this period was limited to one year.

42. In fact, only a rather small and declining share of immigrants entering Austria is covered by the settlement quota system. The system is still formally in place but has lost much of its importance. Most inflows are either free-movement or family members of Austrian and EEA citizens, who have been exempted from quota regulations since 1993. Refugees are also excluded from the settlement quota. With the enlargement of the European Union in 2004 by eight countries from Central and Eastern Europe, the ability of the quota system to regulate the magnitude of migrant flows was further undermined.

43. In spite of the fact that Austria implemented transition arrangements for labour migration from the EU-8 until 1 May 2011, free movement migration from the enlarged EU emerged as the prime source of new immigration. ${ }^{22}$ This trend started already prior to enlargement and in fact, much of the freemovement migration is from the old (pre-2004) EU members (EU-15). Since Austria's accession to the European Union in 1995, the share of foreigners from the EU-15 among the total foreign population has increased steadily, and rose from $15 \%$ to $21 \%$ between the years 2001 and 2009 . More than two thirds of this increase can be attributed to the inflow of Germans, who made up 15\% of the foreign-born in 2009. They represent the largest group of foreign-born in Austria along with immigrants from Serbia (see Table 2).

44. Unfortunately, as explained in Box 1, historical data on "immigrants" in Austria are only available by nationality status and not by country of birth. ${ }^{23}$ An overview of the evolution of the size and composition of the foreign population in Austria since 1961 is provided in Figure 6. Due to lack of detailed data on the nationality of the population before 1981, only the overall evolution of the foreign population is visible prior to that date. Throughout the 1980s and 1990s, the joint share of Turkish and Yugoslav nationals remained steadily above $60 \%$. Their populations grew proportionally with the overall foreign population during the years of record high net migration between 1986 and 1993. Over the past decade, however, their number has started to decline as a consequence of rather high rates of naturalisation (see Lebhart and Marik-Lebeck, 2007). In parallel, the number of foreigners from other lower-income countries and the European Union has grown significantly, both in absolute terms and in relation to the population from the former guestworker countries.

21 For a detailed discussion of the post-2005 legislation and its implications for the labour market access of immigrants, see Bichl et al. (2010).

22 Migration from the new member countries is included in free-movement migration from the time they joined the European Union, because of the significant facilitations for migration in the enlarged European Union even during the transition period which Austria applied, and the fact that member states have only very limited control over the flows. In 2009, almost two-thirds of permanent-type migration to Austria were free movement migration (OECD, 2011).

23 This latter information is only available for the census year 2001 and from 2004 onwards. 
Figure 6. Evolution and composition of the foreign population in Austria, absolute numbers and share in the total population, 1961-2010

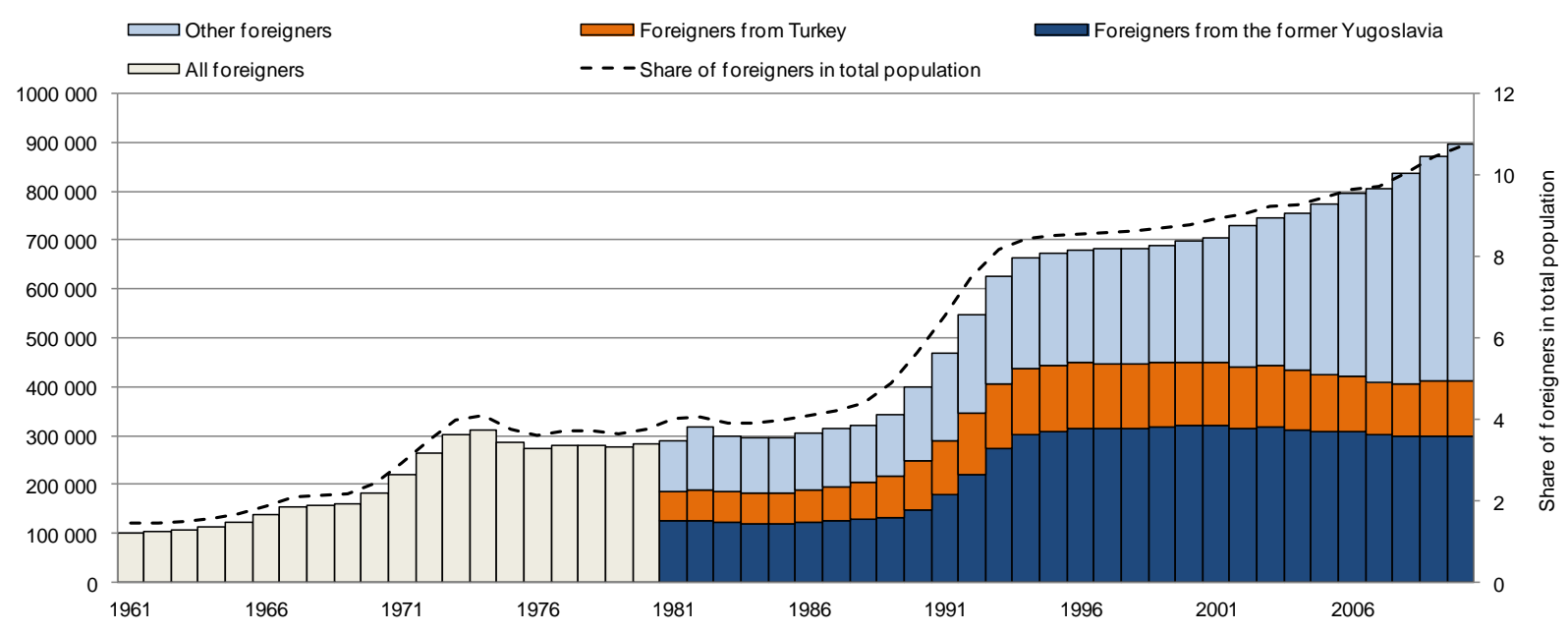

Source: Data provided by Statistics Austria.

45. The composition of recent immigration flows is shown in Figure 7. As can be seen, free movement is by far the most important category of entry for new permanent-type migration. Migrants from the enlarged European Union (EU-27) accounted for almost $60 \%$ of inflows in 2009. Family migration remains the most important category for migrants from outside the EU, followed by humanitarian migration. Labour migration from outside of the EU-27 accounts for only a negligible share of inflows.

Figure 7. Permanent inflows into selected OECD and non-OECD countries, as a percentage of the total population, by category of entry, 2009

\section{$\square$ Work $\square$ Accompanying family of workers $\square$ Free movement $\quad \square$ Family $\quad$ Humanitarian and other}

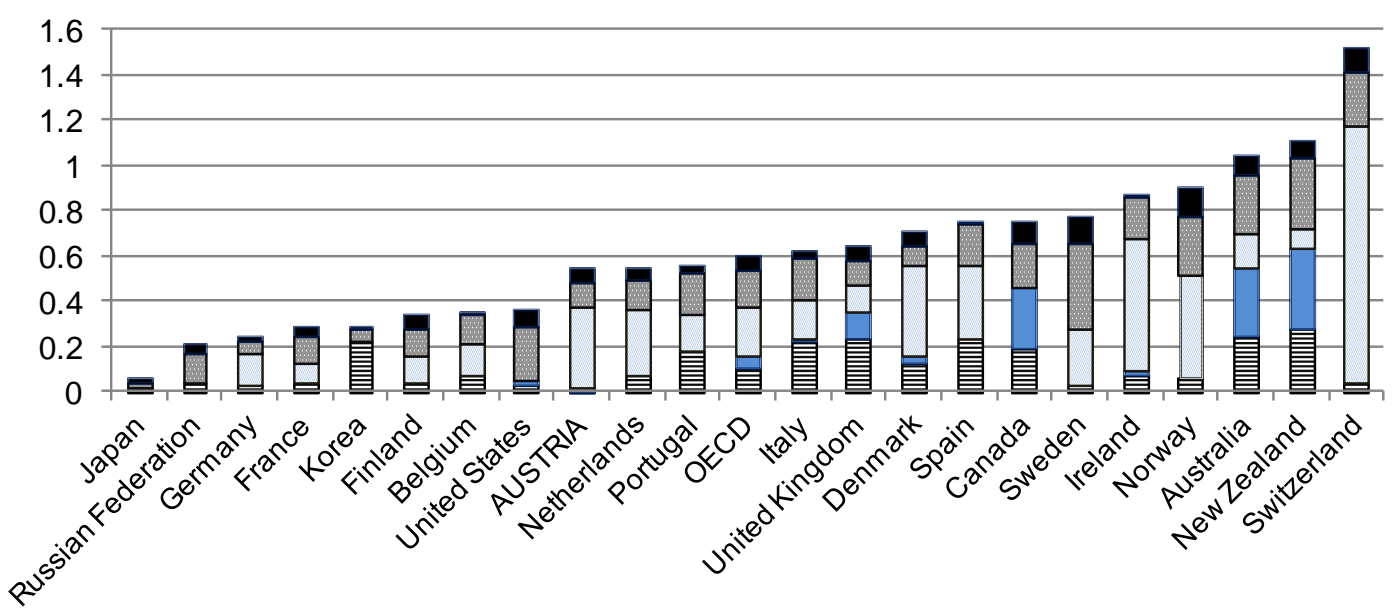

Source: OECD International Migration Outlook (2011b). 
46. In order to increase the scale and scope of skilled labour migration from non-EU countries, Austria introduced a so-called "red-white-red-card" for the selective recruitment of skilled labour migrants The scheme gradually introduces a points-based system for the admission of skilled and highly-skilled labour migrants starting on the $1^{\text {st }}$ of July 2011. It includes both a supply-driven job-search visa for highlyskilled migrants without a job offer and a demand-driven tier for migrants with a job offer in a shortage occupation or having passed a labour market test (for a detailed discussion of the red-white-red-card and the measures that accompany it, see box 3 , as well as Bichl et al., forthcoming).

\section{Box 3. A new labour migration system for Austria: the "Red-White-Red" card}

Austria has started to gradually introduce a new criteria-based immigration scheme in July 2011. The so-called Red-White-Red Card Model (RWR Card) aims to allow for a more flexible immigration of qualified labour migrants from outside of the European Union and their families who wish to settle permanently in Austria. The model accounts for both personal (i.e. related to the applicant) and labour market criteria with the most important factors being qualification, work experience, age, language skills, a job offer and minimum remuneration (see OECD 2011b for a full list of the criteria and their weights and a comparison with points-based systems in other OECD countries).

The RWR Card scheme introduces two new titles of residence that are linked to a work permit. The RedWhite-Red Card entitles to residence and employment with a specific employer for a period of twelve months. After at least 10 months of continuous employment, a Red-White-Red Card Plus, which grants unrestricted labour market access, can be issued to replace the first title.

Three groups are targeted by this reform in the sense that they can obtain an RWR Card to come to Austria if they fulfill the requirements of the points-based system. "Very highly-qualified" migrants can obtain a RWR-card through a supply-driven tier of the points-based system, that is, they do not need to have a job offer. They may be issued a six-month visa for the purpose of searching for an employment in Austria if they achieve a certain minimum amount of points. After finding an adequate job in Austria, they can then obtain a „Red-White-Red“-Card "Key workers” who have passed a labour market test and skilled workers in shortage occupations can obtain a RWR-card in the demand-driven tier if they have a job offer and have reached the level of points required.

International graduates of at least master level programmes can obtain a job-search visa. If they succeed in finding a job that corresponds to certain criteria within six months after graduation, they can change their status into a RWR card (again restricted to a specific employer and limited to one year maximum). They are exempt from the points-based system, but like the other groups of migrants have to apply for a "RWR Card Plus" after one year to gain unlimited labour market access.

The "RWR Card Plus" is also given to the family members of the above-mentioned groups of migrants, as well as to holders of an EU Blue Card and their family members. It can also be issued to family members of foreign nationals that have already settled permanently in Austria. Family migrants wishing to obtain the RWR Card Plus need to pass a language examination at the A1 level of the Common European Framework prior to entry. Only family members of "very highly-qualified" holders of the RWR Card who have entered through the supply-driven tier are exempt from this requirement.

While the bulk of reform measures accompanying the introduction of the RWR card scheme came into effect in July 2011, skilled workers in shortage occupations (i.e. without labour market test) will have to wait until at least May 2012 before they can apply for a title under this scheme.

\section{The evolution of integration policy}

47. In spite of the longstanding presence of immigrants in Austria, integration policy developed rather recently. Over most of the post-war era, Austrian policy with respect to foreigners was closely linked to the notion of guestworker migration, which was built upon the concept of rotating, temporary inflows of foreign workers. This policy did not envision Austria as a destination country for permanent migrants and as a consequence was not concerned with the issue of integration. The circumstances for 
integration were largely shaped by the Act on the Employment of Foreigners (Ausländerbeschäftigungsgesetz), which determined immigrants' labour market access and has traditionally represented the most important tool of Austrian integration policy.

48. In the 1970s and 1980s, there was no formal integration policy, with the exception of support measures for recognised refugees that were, for instance, provided by the Austrian Integration Fund (see below). There was also some language training in German and "mother-tongue" instruction for children of immigrants that would help to prepare them for their eventual return to their countries of origin. These measures were, however, not formalised by law until 1992. Indeed, partly a heritage from the times of guestworker migration, so-called "mother- tongue" instruction is still a rather strong element of the education of the children of migrants in Austria today (see Section V). Until the end of the 1980s, apart from a few local initiatives, Austria had not implemented major measures to promote the integration of immigrants.

49. Austrian integration policy only started to adjust to the fact of the permanent settlement of immigrants in the late 1980s, when many of the former "guestworkers" and their families had already been living in Austria for more than fifteen years. In 1988, it became easier for immigrants to obtain an "exemption certificate" and its duration was extended to three years. Moreover, labour market access was liberalised for children of immigrants who did not have Austrian nationality. While they had been treated like new arrivals after completion of education by the old law, they could now generally obtain an "exemption certificate" (see Deutsch et al., 2010). ${ }^{24}$

50. The rather late development of integration policy at the federal level in Austria must be seen in the context of decision- making in this domain. Until 1993, migration policy and labour market integration remained largely under the responsibility of the social partners who discussed related topics as part of their negotiations about labour market and welfare policy. Debates on this issue largely occurred outside of the parliament and public sphere and were thus hardly politicised until the early $1990 \mathrm{~s} .{ }^{25}$ This changed in the aftermath of the record-high inflows of the years 1989 to 1993. Responsibility for migration policy was shifted from the social partners to the Federal Ministry of the Interior and with rising anti-immigrant sentiments in the population, the topic started to gain more weight in the political debate.

51. Only in 1997 was a formal federal framework for integration established, which mainly consisted of acknowledging the permanent presence of immigrants in Austria through legal measures. A so-called Integration package stipulated the principle of "integration before new immigration", restricting the entry of new immigrants through labour and family migration while improving the legal status of long-term migrants. For those who had resided in Austria for more than eight years, the right to stay was made independent of the previous necessity to have sufficient means of subsistence. About half of the immigrants from outside the EU who were living in Austria at that time and had not entered as asylum seekers benefitted directly from this amendment (Gächter, 2008). Since 1999, foreigners have had the same rights as nationals to receive unemployment benefits, provided they have contributed to the social security scheme. ${ }^{26}$

52. A second major step was taken in 2003 when the government introduced a so-called "integration agreement" that targeted new arrivals. Under this agreement, immigrants from outside the EU - in practice almost exclusively family migrants since refugees and labour migrants are exempted - have to commit

\footnotetext{
24 The majority of immigrant offspring did not have Austrian citizenship at that time, but the number of those at working age was still rather small as well.

25 For a thorough discussion of the social partners' role in Austrian integration policy, see Bauböck (1988).

26 Compared with other OECD countries, these rights have been extended rather late to foreigners.
} 
themselves to obtaining a basic level of German-language proficiency within a certain period of time after their arrival in order to acquire a permanent residence permit. In its original (2003) version, the agreement demanded immigrants to attend a language course leading towards A1 level in the European reference framework for languages within four years after arrival. In 2006, the required level of German proficiency was raised to the A2-level and the acquisition period was extended to five years. In addition, immigrants had to pass a final examination at the end of the course. Moreover, the scale of available preparatory courses was enlarged, and additional literacy courses were introduced. ${ }^{27}$ Failure to fulfil the integration agreement could, under certain conditions, lead to administrative fines and theoretically also to expulsion.

53. Since July 2011, obligations to learn German have been strengthened further and the integration agreement has undergone a third overhaul. In principle, all migrants from non-EEA countries (as well as from Romania and Bulgaria until 2013/2014) who are neither labour migrants nor part of the family of labour migrants or of EEA citizens have to provide proof of basic German language knowledge (A1-level) prior to immigration, if they apply for certain categories of residence titles. There are a number of exceptions, namely for minors, for people who cannot reasonably be expected to provide such evidence because of their physical or mental health condition, for family members of holders of certain residence titles ("Blue Card EU" and "Long-term Residence Permit - EC") as well as for highly qualified persons. In parallel, the period for obtaining the required level of German for the fulfilment of the integration agreement (that is, the A2-level) has been reduced to two years after immigration. At the same time, for obtaining permanent residence status and for naturalisation, a higher language proficiency (at the B1-level) is now required for all non-EEA migrants (including labour migrants). ${ }^{28}$ Exemptions apply to persons being underage when applying and to persons who cannot reasonably be expected to provide such evidence because of their physical or mental health condition.

54. The framework for integration policy that has evolved since 2003 is marked by two main characteristics that are both reflected in the integration agreement. The first is its strong focus on linguistic integration. The attainment of German-language proficiency is emphasised as a key to social, economic and cultural integration and the main feature of the integration agreement. The second key feature is the mandatory character of integration measures. The integration agreement specifies both the obligation and the right of immigrants to participate in the courses provided, but fees are only partly refunded.

55. A national action plan for integration was adopted in January 2010. The plan essentially takes stock of existing measures relating to seven fields of action such as the labour market, education, housing, health and the social system, leisure activities and public opinion. Its main goal is to enforce co-ordination of the different actors in the field of integration policy. The integration-coordination-process and the development of appropriate measures are supported by an independent "expert board" (established in 2010). The first Austrian Integration Report was presented in July 2011 and includes 20 sets of measures within the seven fields of action.

\section{The Austrian labour market setting}

56. A key feature of the Austrian labour market is the tripartite nature of policy setting. In particular, wage policy is largely oriented by macroeconomic conditions and shaped by the social partners. Wage negotiations occur at the sectoral level on a yearly basis, where increases of collective wage contracts and

27 Moreover, exemption criteria for the obligation to sign the agreement were reduced. The agreement is to be signed by third-country nationals who are at least 9 years old upon arrival and cannot provide evidence of equivalent German language proficiency, for example though education diploma. Recognised refugees are exempted, as well as key workers and persons whose state of health or age is an obstacle to their participation.

28 For a comprehensive discussion of naturalisation policy, citizenship testing and its links with integration in Austria, see Perchinig (2009) and Reichel (2011). 
the so-called "actual wage" paid to employees are negotiated. Within firms, further increases (overpayments) of the "actual wage" can be negotiated either individually or between the work council and management. ${ }^{29} \mathrm{~A}$ certain coordination of wage policy takes place even at the firm level, due to the close links between work councils and the unions. There is no statutory minimum wage in Austria. However, the agreed-upon wages in collective agreements - which must not be lower than EUR 1000 (on a full-time monthly basis, paid 14 times per year) - cannot be undercut. Wage differentials with respect to gender, age and industry are relatively high by international standards (see e.g. Böheim et al., 2011; and Hofer et al., 2001). ${ }^{30}$

57. The labour market is relatively flexible, and the level of employment protection is somewhat below the average of European OECD countries. In particular, individuals aged 25-50 can easily be dismissed. Job turnover is high in Austria. In 2010, 1.59 million new employment contracts were concluded and 1.55 million contracts terminated compared with a total employment of 3.36 million. This dynamic can be explained in a large part by the high seasonality of employment in Austria. Two of the main industries in Austria are construction and tourism, accounting for 9\% and 6\%, respectively, of total employment. These experience significant seasonal fluctuations in demand and are also sectors in which immigrants are strongly overrepresented. In 2009/2010, according to data from the Austrian Microcensus, immigrants accounted for $20 \%$ of employment in construction and 33\% of employment in tourism (compared with $16 \%$ in total employment). Annex Table A4 provides an overview of the sectoral distribution of employment for the native- and foreign-born populations by gender.

58. The institution primarily responsible for the implementation labour market policy in Austria is the Public Employment Service (AMS). The AMS is responsible for tasks such as the placement of workers, support with the elimination of placement barriers, implementation of measures to raise labour market transparency, reduction of qualitative imbalances between labour demand and supply through training and retraining programmes, preservation of jobs if this is in line with active labour market policy, and securing the livelihood of the unemployed through unemployment insurance. The concentration of the responsibility for placement activities and the disbursement of unemployment insurance benefits within the AMS is intended to secure the effectiveness of the principle of activation before passive benefit receipt.

59. The Austrian welfare model is employment-centred. The eligibility for transfer payments depends mainly on integration in the labour market. The tax burden on labour is relatively high in Austria, particularly due to the relatively high social security contributions, and the tax wedge (i.e. the sum of income tax and employer and employee contributions to social security as a percentage of labour costs) in Austria is well above the EU average. The relatively high marginal tax burden for low-income earners among which immigrants are likely to be overrepresented - provides negative incentives to work. The states are responsible for social assistance, which used to be reflected in considerable differences in terms of requirements, types of services and the organisational and financial structure of the respective programmes. The introduction of a means-tested basic income scheme (Bedarfsorientierte Mindestsicherung) in 2010 should lead to a harmonisation of the different systems (uniform cash benefits, access conditions, conditions regarding repayment and recovery of benefits). One goal of the reform is the better integration of recipients into the labour market. The reform also aims to create one-stop-shop at the AMS, which should enhance the access to active labour market programmes for groups more distant from the labour market, among which immigrants are overrepresented.

29 A comprehensive description of the institutions of the Austrian labour market is provided in Hofer and WinterEbmer (2007).

30 There has been no study of the wages of immigrants in Austria thus far. Indeed, the only dataset which includes both information on country of birth and of wages is the EU Survey of Income and Living Conditions. However, the samples of immigrants from lower-income countries in Austria are small. 
60. In recent years, the temporary employment sector in Austria has experienced significant growth. A recent evaluation (Riesenfelder and Wetzel, 2010) has shown that temporary employment agency work grew more than threefold in Austria between 1998 and 2008. Much of the growth has been attributable to persons with a migrant background, whose share among temporary employment agency workers has increased from about $20 \%$ in 1998 to about $35 \%$ in 2008.

\section{Key actors}

61. In all OECD countries, the labour market integration of immigrants and their children is shaped by a multitude of actors. Nevertheless, in no other OECD country that has been under review thus far, appears the resulting framework to be as diversified as in Austria. The main actors include a broad range of ministries and agencies in the federal administration, the federal states and the municipalities, as well as the social partners.

62. Since the early 1990s, the Federal Ministry for the Interior (BMI) has been charged with the legal regulation of inflows, citizenship legislation, as well as the administration of residence permits and asylum procedures. It also maintains the relevant registers and statistics on permits and asylum requests. The ministry has recently increased efforts to co-ordinate the different actors in the field of integration policy, notably through the introduction of the National Action Plan for Integration in 2010. In April 2011, the BMI created a separate State Secretariat for Integration. Its competences are mainly the nationwide coordination of integration measures and the sponsorship of related integration projects. Furthermore, the BMI deals with aspects related to the admission and residence of immigrants, as well as with the implementation of the integration agreement.

63. The BMI is also in charge of enforcing the integration agreement that it implements jointly with the Austrian Integration Fund (ÖIF), an independent agency founded in 1960 by the BMI and the United Nations High Commissioner for Refugees (UNHCR). The ÖIF had originally been a provider of care and services for humanitarian migrants, and gradually extended its services to other migrant groups. In 1991, it was outsourced from the BMI as an independent agency and is mainly in charge of administering the integration agreement through co-funding language courses and evaluating and certifying institutions that provide them. The ÖIF also assists the BMI in the distribution of resources from the European Refugee Fund (ERF) and the European Fund for Integration (EIF) and maintains four integration centres (in Vienna, Tyrol, Styria and Upper Austria) for immigrants, in particular refugees. These centres provide information and counselling on a broad range of integration-related aspects. The ÖIF also recently established a "House of Education and Professional Integration" in Vienna which provides a range of labour market-related services to immigrants.

64. In 2010, the BMI provided the ÖIF with a budget of EUR 11 million and spent an additional EUR 1.5 million on the National Integration Plan. It also contributed some EUR 3.3 million to the funding of integration projects such as language courses, career guidance and training for children of immigrants and refugees that were partly implemented at municipal level.

65. A new Federal Office for Asylum and Migration ("Bundesamt für Asyl und Migration", BAM) is planned to be established as from late 2011. The new office is intended to shorten and simplify procedures and to unite the tasks of currently 194 agencies in one administrative unit. With respect to labour market integration, the Federal Ministry of Labour, Social Affairs and Consumer Protection (BMASK) plays the main role, as it administers the Law on the Employment of Foreigners and has the authority to regulate labour market access. The BMASK is also responsible for the administration of social security in Austria. Most importantly, however, the BMASK defines the framework for active labour market policy in Austria which is implemented by the $A M S$. There is no direct information available on the funds allocated to the labour market integration of immigrants. Information is only available on the cost of active labour market 
policy measures (including active labour market policy for skills training and part-time allowance for older workers) spent on foreign nationals, and this amounted to EUR 230 million in 2009, twice the 2005 level (BMASK, 2010a). The AMS is organised in agencies at federal, state and municipal levels and the offers provided to immigrants differ accordingly. The AMS offices in some states, such as Vienna and Upper Austria, have provided specific labour market measures that, although not directly targeted at immigrants, have strong indirect targeting (see Section IV below).

66. As already mentioned, the social partners play a rather unique role in Austria and have important competences in overall labour market and social policy. In addition to their role in policy-making, they offer a range of services that are provided in other OECD countries either by the governmental agencies or by other, non-governmental organisations. The Chambers of Labour, for instance, offer legal advice in cases of perceived discrimination at the workplace, as well as language and general skills training to all members. Box 4 gives an overview of the activities of the social partners in the field of integration.

\section{Box 4. Integration activities of the social partners}

Austrian labour market policy is strongly shaped by the principle of social partnership which ranks amongst the most highly developed in the OECD. It favours voluntary co-operation and the reconciliation of interests between the state, employers and employees. The social partners have traditionally exerted a strong influence on migration policy. Among the social partners, the key actors for integration are the Chambers of Labour on the employees' side and the Federal Economic Chamber as the representation of employers' interests.

The Chamber of Labour is organised on a federal basis with each federal state having its own chamber. Membership is life-long and compulsory upon entrance into the labour market, except for employees in agriculture and civil servants. The Chamber of Labour is not directly involved in collective bargaining, wage agreements or the organisation of strikes which lie within the remit of the Trade Union Federation. The Chamber is rather a think-tank, providing expertise and lobbying, as well as a range of other services for its members such as legal consultation and consumer protection.

Vienna has a particularly large immigrant population and the local Chamber of Labour is strongly involved in shaping their labour market integration. It notably provides personalised legal advice in roughly 40000 cases per year, half of which are requested by members with a migration background. As this group only makes up one third of the Viennese Chamber's members, immigrants are overrepresented among those seeking legal support. Legal advice is frequently called on in cases of perceived discrimination at the workplace. However, such inquiries are rarely successful, as immigrants find it hard to provide proof of having been discriminated against. Besides that, it offers education vouchers and language training to its members and engages in supporting the school-to-work-transition of young people by organising a job fair and by keeping contact with problematic schools. Finally, there is a programme that trains children to become "multipliers" by informing their peers about issues of discrimination. The chamber is currently developing a diversity concept for its own employees and has started to recruit bilingual legal consultants of immigrant origin.

The Austrian Federal Economic Chamber is the legal representation of all Austrian businesses. Altogether, the organisation comprises more than 400.000 member businesses. Membership of the Austrian Federal Economic Chamber, the provincial chambers and the associations is governed by law and constituted by the exercise of an economic activity. Among the tasks conferred by law upon the Austrian Federal Economic Chamber is the responsibility to balance and represent the interests of all Austrian businesses, to promote the economy and to communicate knowledge.

The topic of immigrants' labour market integration has gained prominence for the Economic Chamber in recent years. The Chamber launched a mentoring project in 2008 which is still ongoing. Over a period of six months, a migrant who is skilled but unemployed or overqualified in his job is tutored by a person well integrated into the Austrian economy. The latter shares his or her knowledge of the Austrian labour market and recruitment system, as well as the social network with the mentee. This partnership aims at equipping migrants with social capital that will empower them over the long run, rather than just assisting with job search. Thus far, 450 mentoring couples have participated in the programme that the Economic Chamber runs jointly with the Austrian Integration Fund and the Public Employment Service. After having started in Vienna, the project was extended to three more federal states. 


\section{Box 4. Integration activities of the social partners (cont'd)}

A range of projects and initiatives are run by the local economic chambers. The Viennese chamber, along with the federal chamber, for instance, provided language training in business German for 80 participants in 2010. In the same year, the economic chamber of Upper Austria was engaged in enhancing access to information and consulting for migrant entrepreneurs. Since 2008 it has also been involved in a project that aims to foster the labour market integration of youth with a migration background.

67. Both the Chamber of Labour and the Economic Chamber, as two of the key representatives of employees' and employers' interests, respectively, have only recently started to account for the growing diversity of their members in their organisational structures. The right of foreign citizens to be elected as a representative was only formalised in 2006 by the Chamber of Labour. In the Economic Chamber, only Austrian nationals have passive voting rights. Since 2010, however, Turkish entrepreneurs can run for representative posts in the Economic Chambers, on the basis of a bilateral agreement.

68. Regarding the education of immigrants and their children, responsibilities are distributed among several actors. While the Federal Ministry for Education, Arts and Culture (BMUKK) defines the legislative framework for language training in pre-, primary and lower secondary schools, the actual implementation is partly taken over by the federal states. ${ }^{31}$ Municipalities are in charge of maintaining schools and headmasters and enjoy considerable autonomy in budgetary matters (see OECD, 2009a). Due to this fragmentation, the quality and availability of integration measures for the children of immigrants varies widely (see Section V). Adult education for migrants is mainly provided in educational institutions that are financed by the social partners.

69. The recognition of foreign qualifications is also shared by four different ministries, namely the Federal Ministry for Science and Research that maintains the National Academic Recognition Information Centre (ENIC-NARIC Austria) and is in charge of academic diplomas, the Federal Ministry of Economy, Family and Youth in matters of vocational education and training, as well as the Ministry for Education, Arts and Culture and the Ministry of Health with respect to school-leaving diplomas and healthcare qualifications, respectively.

70. Most federal states have recently adopted a formal integration strategy or are currently in the process of doing so. These strategies stipulate a range of policy goals that aim at securing a continuous long-term commitment to integration, regardless of changing political regimes. Since the introduction of the first municipal integration strategy by the city of Dornbirn in 2002, more and more small- and mediumsized cities have developed their own concepts of integration policy. In 2009, three quarters of all cities with more than 20000 inhabitants either had developed an individual integration strategy or had adopted the strategy of their federal state (Antalovsky et al., 2009).

71. As in other OECD countries, a large part of integration policy in Austria is implemented at the local level. The allocation of social services, for instance, is administered through the BMASK, but delivered largely by the municipalities. Likewise, the BMUKK sets the framework for early childhood education and language training in schools, while the municipalities secure its provision. The municipalities also administer the provision of communal housing and many of them reserved these facilities for Austrian and EEA nationals until 2005. After that, access was liberalised nationwide as a measure of harmonisation with EU legislation.

31 The federal states are in charge of implementing education policy in pre- and primary school, as well as in the lower track of lower secondary education. In contrast, the higher track of lower secondary education and upper secondary education and above are in the responsibility of the federal government (for a detailed discussion of the Austrian education system, see Section V). 
72. A particularly important role is played by Vienna, which is both a city and a state, and which hosts $42 \%$ of the immigrant population in Austria (for an overview of the labour market integration of immigrants in Vienna, see Biffl et al., 2008). Particularly strong is the presence of children of immigrants. $43 \%$ of the underage population is either foreign-born or native-born with two foreign-born parents. Because of this strong immigrant presence, there is a broad range of services available to immigrants and their children. For example, the Viennese AMS maintains a special agency for youth. Although migrants are not yet an official target group, they are still targeted indirectly since more than $60 \%$ of the youth agency's clients have a migration background. Vienna also offers a number of integration activities with a specific focus on refugees and on immigrant women. It has also established a specific fund, the Vienna Employment Promotion Fund (Wiener ArbeitnehmerInnen Förderungsfond, WAFF), which provides a range of services to migrants (among other groups), including counselling and financial support for training. The municipal administration, moreover, maintains a separate department for integration and diversity (Magistratsabteilung 17) that promotes diversity within the administrative body (see Magistratsabteilung 17, 2009). It also runs a range of support measures such as language-support programmes linked with a childcare facility for immigrant mothers.

73. Where the public infrastructure has been lacking, non-governmental organisations (NGOs) have generally stepped in, albeit rarely in a way that would ensure a co-ordinated and nation-wide coverage. An exception is the field of anti-discrimination policy. About 22 NGOs are grouped under the Litigation Association Against Discrimination (Klagsverband) that was founded in 2004 as an umbrella organisation of NGOs and provides legal assistance and general information on anti-discrimination. They are an important complement to public anti-discrimination policy that is not yet comprehensive. Key actors at the federal level are the Equal Treatment Commission and the Ombud for Equal Treatment under the auspice of the Federal Chancellery's division for Women and Gender equality, which provide a means for potential victims of ethnic discrimination to have their case evaluated in terms of the anti-discrimination law before actual court proceedings need to be enforced. Equal treatment commissions also exist at state level. The extent to which these official facilities are used remains, however, limited thus far.

74. Other NGOs and the welfare services of the Churches assist immigrants and asylum seekers with finding housing and employment, provide shelter and counselling centers, as well as legal advice and short-term financial support. Such NGOs, furthermore, offer language courses, including special training opportunities for children with special needs and special assistance and training opportunities for women.

75. Compared with the other OECD countries that have been under review thus far, immigrant associations seem to be less developed in Austria and are essentially small-scale. Until the 1980s, immigrant associations focused on the maintenance of ethnic identities, traditions and links with the countries of origin, rather than on promoting their members' integration into Austrian society. This was a response to the insecure residence status of many migrants in Austria, who faced the constant risk of being sent back to their countries of origin. In recent years, migrant associations have received more financial support to help them to professionalise their structures and to provide integration measures.

\section{Migrants' position in the labour market: some key issues}

\section{The labour market access of immigrants and the outcomes of recent arrivals}

76. Evidence from a number of OECD countries suggests that early participation in the labour market is a key determinant of future labour market performance for immigrants, and several OECD countries have put a lot of effort into preparing immigrants to enter the labour market and take up employment soon after arrival. In Denmark, where policies in this respect are particularly strong, this 
strategy has been associated with significant improvements in the labour market outcomes of new arrivals in recent years (see OECD, 2007).

77. One of the basic preconditions for migrants' entry into the labour market is that they have full access to the latter, without a labour market test or other administrative burdens for employers which would prevent them from employing immigrants. Indeed, there is little reason for putting administrative obstacles in the way of early labour market entry for migrants who can be expected to stay in the country for good, and all OECD countries that have been under review by the OECD thus far generally provide permanent-type migrants with full access to the labour market upon arrival.

78. Austria is among the few OECD countries that do not automatically grant full and immediate labour market access to all permanent-type migrants. The Austrian framework is rather complex and has changed repeatedly since the late 1980s (for an overview, see Deutsch et al., 2010). Recognised refugees, persons under subsidiary protection and family members of an EEA citizen get full and immediate labour market access. Other new arrivals (essentially family migrants of non-EEA citizens) are subject to the requirement of having a work permit until they can change status to an "unrestricted permanent residence permit" which already includes the entitlement to work; for family migrants of non-EEA citizens this is generally possible after a year. In essence, only a small group of resident (permanent-type) migrants thus still needs a separate work permit.

79. To obtain such a permit, a number of requirements have to be met, including passing a labour market test. In addition, the employer needs to request the work permit. In practice, this means that the labour market is essentially closed for migrants concerned by these regulations, as only the highlyeducated and specialists will both pass the labour market test and find an employer willing to go through the red tape to hire them.

80. The requirement of a work permit was abandoned for most of the remaining migrant groups still subjected to it, notably the majority of family migrants, in the framework of the comprehensive reform of the immigration framework which entered into force in July 2011. It remains, however, in place for a few, relatively small groups of immigrants. The main group for which a work permit will continue to be required is temporarily admitted humanitarian migrants who do not have a certification of basic knowledge of German. For those migrants among this group who will remain in Austria, the lack of labour market access is unfortunate not only because of the negative impact on employment prospects, but also since having a job tends to have important spillover effects to other integration outcomes, including mastery of the host-country language. In addition, this group has access neither to subsidised language training through the integration courses nor to the free language training provided by the AMS (since they are not yet part of the labour market). At the same time, because of the lack of labour income, they will often not have the funds for privately-provided language training.

81. One (again small) group which currently does not have any labour market access - at least initially - are migrants who have arrived as adult immigrant offspring and other (non-core) family migrants. They can only access the labour market if they manage to change status to an unrestricted permit after five years. In order to do so, however, a stable source of income is required - something which tends to be difficult for persons who are not allowed to work.

82. The provisions regarding labour market access of asylum seekers are also rather restrictive. Most OECD countries provide labour market access for asylum seekers at some stage after arrival, although the provisions vary - from three months in Finland to twelve months (plus a labour market test) in Germany. In Austria, employment of asylum seekers is currently only possible after three months and only for seasonal work after a labour market test, and upon employer request. Given that asylum procedures can be rather lengthy before some kind of humanitarian permit is granted, this means that a significant proportion 
of immigrants who will remain in Austria on humanitarian grounds may have to wait for many years before getting in touch with the regular labour market. ${ }^{32}$

83. As explained in Section II above, since 1993 the issuance of a work permit is subject to numerical limits which essentially aim at ensuring that new work permits can only be granted if the share of migrants in the labour market who are neither EEA migrants nor recognised refugees does not exceed a certain percentage, currently $7 \%$. The current share is a little over $6 \%$ and indeed, the quota has generally not been reached over the past decade. Even if this figure were reached, a special ordinance by the Minster of Employment would allow for granting additional work permits to most migrant groups up to a further limit of $8 \%$ of the workforce. Different numerical limits also used to apply at the regional level where they depended on the already resident population, further adding to the complexity of the system. These regional limits were abolished under the new post-July 2011 immigration framework.

84. Indeed, the labour market access of immigrants has become significantly liberalised over the past fifteen years, partly driven by EU directives such as notably the directive on family reunification. Prior to 2003, when the latter directive was implemented in Austria, the labour market test applied for family migrants from non-EEA countries during the first five years of residence; until 1998, the waiting period was eight years. Until 2007, the provisions were similar for persons with subsidiary protection who account for the bulk of humanitarian migrants to Austria. In that year, the waiting period was abolished.

85. Figure 8 shows the differences in the employment rates between immigrants and the native-born by duration of residence. As can be seen, the differences are pronounced in Austria over the first five years for women from lower-income countries, in particular for those from Turkey. A worrying trend is that the gaps for newly-arrived vis-à-vis the native-born women increased for all groups between 2004/2005 and $2008 / 2009$, in spite of various policy measures which intended to improve their integration outcomes, including the "integration agreement" which was introduced in 2003 for family migrants and extended in 2006, strengthening its compulsory component.

Figure 8a. Percentage-point difference in the employment rates of immigrants compared with the native-born in selected OECD countries, by duration of residence and gender, aged 15-64, 2008/2009
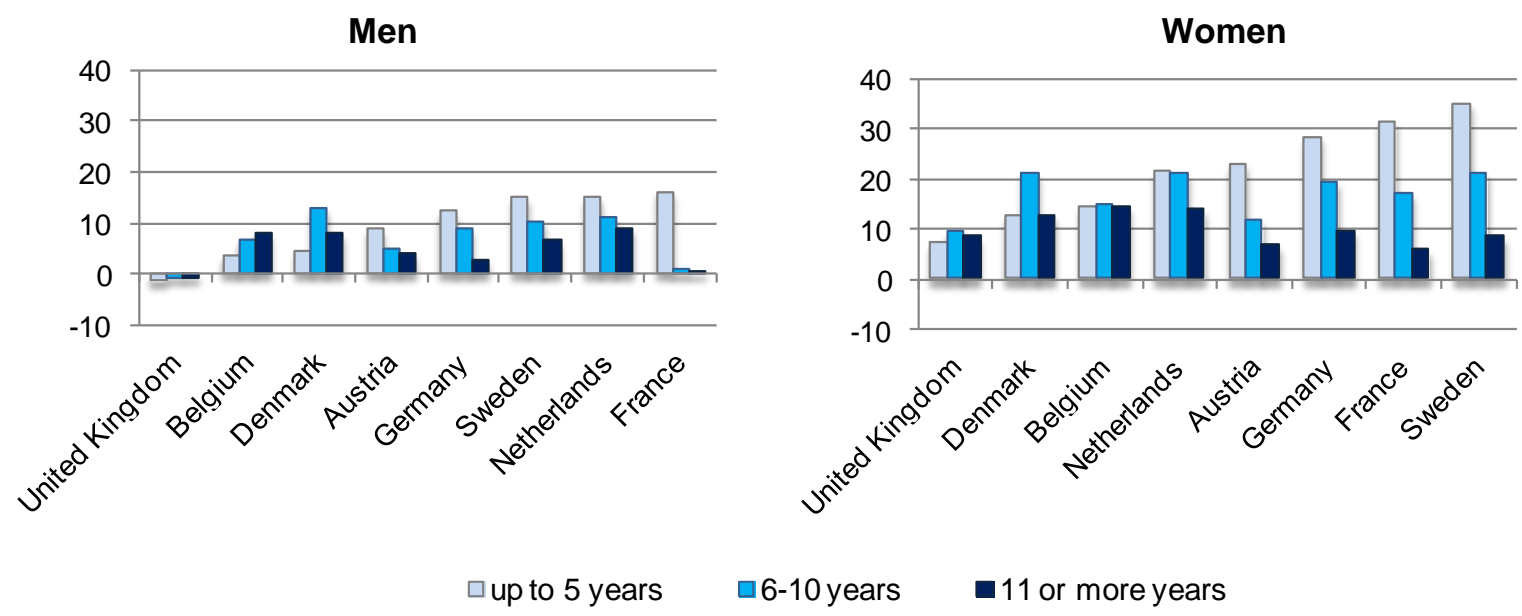

Source: Austrian Microcensus (data provided by Statistics Austria).

32 Nevertheless, the asylum procedures have been accelerated since 2007. Lengthy procedures have often resulted from the distinct legal protection offered by Austria to asylum seekers. Austria has provided a wide range of legal remedies that goes beyond those offered by many other EU member countries. Moreover, it must be considered that Austria still has one of the highest shares of asylum seekers in the OECD. 
Figure 8b. Percentage-point difference in the employment rates of immigrants compared with the native-born for different immigrants groups in Austria, by duration of residence and gender, aged 15-64, 2004/2005 and 2008/2009
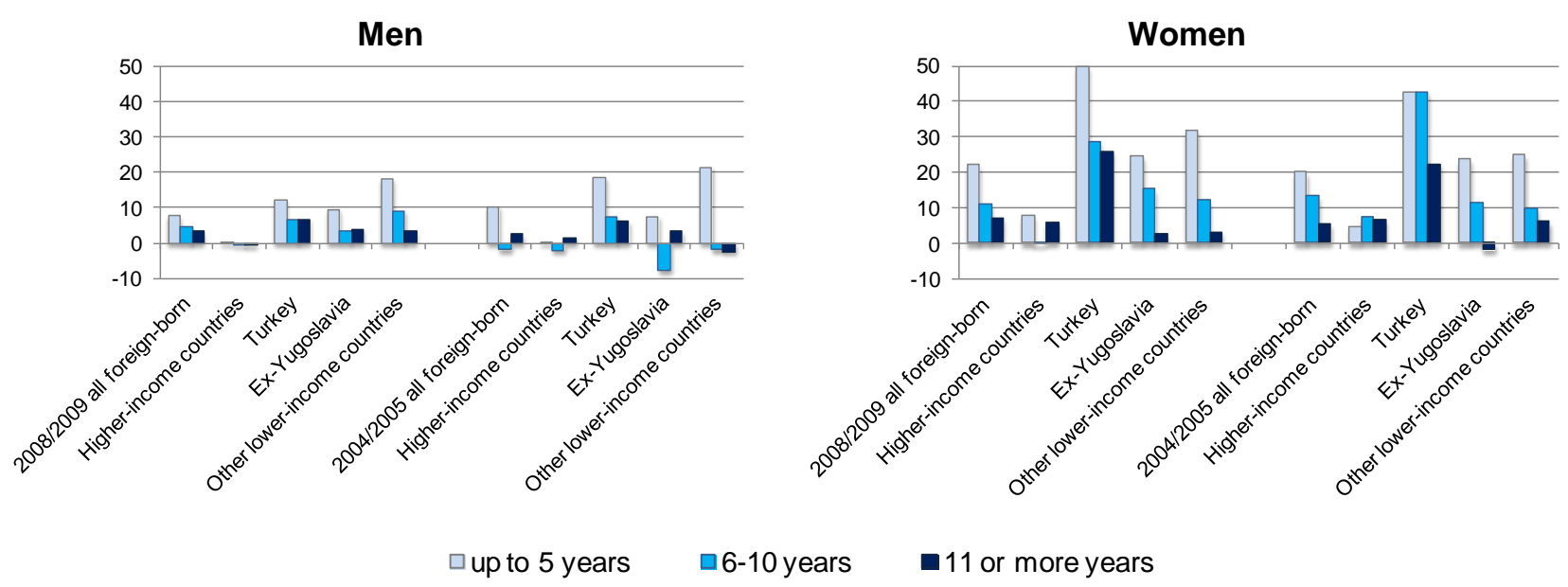

Source: Austrian Microcensus (data provided by Statistics Austria).

86. Evidence from other OECD countries (e.g. Clausen et al. 2008) points to "lock-in" effects of language training, as it may prevent participants from entering the labour market. However, it is unclear to what extent, if any, such effects are responsible for the declining labour market performance of recently arrived women from lower-income countries in Austria.

87. Although the overwhelming majority of permanent-type migrants now enjoy full labour market access, there seems to be little reason for the remaining exceptions. In addition, they make the system highly opaque and may prevent employers who have little experience with hiring foreigners from doing so - and this can have a negative impact even on those many migrants who do enjoy full access.

\section{The integration of immigrant women}

88. As noted, immigrant women from lower-income countries appear to have been particularly hit by the above-mentioned significant restrictions in labour market access which have been in place until recently for many non-labour migrants during the first years of residence. Since early labour market integration is an important determinant of integration outcomes in the long run, these past restrictions may still negatively impact on the labour market integration of immigrant women.

89. Indeed, as seen in the overview in Section I, immigrant women have relatively unfavourable labour market outcomes in Austria. This holds in particular for those from Turkey, who have both the lowest employment rates (only 38\% of those in working-age are employed) and the highest unemployment rate (13.6\%, almost four times the level for native-born women) among all major origin groups.

90. Other factors have also contributed to this unfavourable labour market position. In particular, the education level of immigrant women from Turkey is particularly low - more than three quarters have at most lower secondary education (see Annex Table A1). However, even after accounting for this, significant gaps in the labour market outcomes still remain for immigrant women from lower-income countries with the notable exception of women from the former Yugoslavia (see Table 3).

91. Another explanatory factor may lie in the lack of incentives to work. However, in contrast to other OECD countries, the tax and benefit system does not provide particularly strong disincentives for second earners with low expected earnings levels. 
92. Finally, early childhood education and care (ECEC) is relatively poorly developed in Austria in international comparison, in spite of significant improvements over the past decade. ${ }^{33}$ As will be seen in more detail in Section $\mathrm{V}$ below, the children of immigrants up to the age of four are underrepresented in ECEC in Austria. There seem to be some links between the low employment rates of immigrant women and the limited participation of children of immigrants in ECEC.

93. An analysis of the association between childbearing and the employment of women is given in Table 3. As can be seen, the negative association between having a child below the age of five and employment is much stronger for immigrant women, in particular for those from lower-income countries. This suggests that they could particularly benefit from a broader provision of ECEC.

Table 3. The association between childbearing and the employment of immigrant women in Austria, aged 15-64, 2009/2010

\begin{tabular}{|c|c|c|c|c|}
\hline Variables & (1) & (2) & (3) & (4) \\
\hline $\begin{array}{l}\text { Turkey } \\
\text { Ex-Yugoslavia } \\
\text { Other lower-income countries } \\
\text { Higher-income countries } \\
\text { having at least one child below age } 6 \\
\text { having at least one child between 6-17 } \\
\text { Child below 6*Born in Turkey } \\
\text { Child 6-17Born in Turkey } \\
\text { Child below 6*Born in Ex-Yugoslavia } \\
\text { Child 6-17Born in Ex-Yugoslavia } \\
\text { Child below 6*Born in other lower- } \\
\text { income countries } \\
\text { Child 6-17*Born in other lower-income } \\
\text { countries } \\
\text { Child below 6*Born in higher-income } \\
\text { countries } \\
\text { Child 6-17Born in higher-income } \\
\text { countries }\end{array}$ & $\begin{array}{c}-30^{\star \star \star} \\
-6^{\star \star \star} \\
-12^{\star \star \star} \\
-3^{\star \star \star}\end{array}$ & $\begin{array}{c}-14^{\star \star \star} \\
3^{\star \star \star} \\
-12^{\star \star \star} \\
-8^{\star \star \star}\end{array}$ & $\begin{array}{c}-13^{\star \star \star} \\
3^{\star \star \star} \\
-11^{\star \star \star} \\
-7^{\star \star \star} \\
-5^{\star \star \star} \\
5^{\star \star \star}\end{array}$ & $\begin{array}{r}-10^{\star \star \star} \\
5^{\star \star \star} \\
-9^{\star \star \star} \\
-7^{\star \star \star} \\
-2^{\star \star \star} \\
4^{\star \star \star} \\
-14^{\star \star \star} \\
5^{\star} \\
-17^{\star \star \star} \\
5^{\star \star \star} \\
-13^{\star \star \star} \\
4^{\star} \\
-6^{\star \star *} \\
5^{\star \star \star}\end{array}$ \\
\hline
\end{tabular}

Note: The dependent variable is the dichotomous variable "employed". The coefficients correspond to an estimate of the parameters of a linear regression on the employment of women between 15 and 64 years. The figures depict the predicted percentage-points difference between the employment rate of the respective group and native-born women in the population. The reference group is native-born women. All models include a constant. Models 2-4 also include control variables for age and educational attainment. , ${ }^{* *},{ }^{* * *}$ denote significance at the $1 \%, 5 \%$ and $10 \%$ level, respectively.

Source: Austrian Microcensus (data provided by Statistics Austria).

94. There have been a number of initiatives, in particular at the state and local level, to promote the labour market integration of immigrant women. The most important measure has been the "Mama lernt Deutsch" (Mama learns German) project in Vienna which provides basic German-language knowledge to immigrant women without prior knowledge of German. More than 5000 immigrant women have participated in these courses since 2006. This training is generally followed up by some more labour-

33 In addition, many immigrant women come from countries where women participate less in the labour market. The low employment rates in origin countries to a certain extent carry over into the destination country after migration However, as seen in Section I, during the crisis an increase in the employment rate of women has been registered among immigrant groups with a low employment rate of women, which demonstrates that these women are reactive to changing labour market conditions and labour needs. 
market-oriented language training or other measures. Since October 2010, these offers are complemented by additional specific literacy training for those women who lack basic qualifications.

\section{Migrants' qualifications and labour market outcomes}

95. A characteristic feature of the Austrian population is the predominance of medium-level qualifications. Among the prime-age population of 25 to 54 years, more than two-thirds of the native-born have as their highest education upper or post-secondary degrees, which is more than in any other country in the comparison group (see Table 4). The proportion of highly-educated, on the other hand, is relatively small and amounts to only $19 \%$, compared with $28 \%$ on average for the OECD countries included in Table 4. This distribution stems from the prominent role of vocational training in the Austrian education system, which will be discussed in more detail in Section V.

Table 4. Distribution (in \%) of the native and foreign-born population, aged 25-54, by educational level, selected high-income countries, around 2008/2009

\begin{tabular}{|c|c|c|c|c|}
\hline & & ISCED 0-2 & ISCED 3/4 & ISCED $5 / 6$ \\
\hline \multirow{3}{*}{ Austria } & Native-born & 13 & 68 & 19 \\
\hline & Foreign-born & 30 & 51 & 19 \\
\hline & Foreign-born, lower-income & 44 & 43 & 14 \\
\hline \multirow{3}{*}{ Belgium } & Native-born & 23 & 41 & 37 \\
\hline & Foreign-born & 39 & 30 & 31 \\
\hline & Foreign-born, lower-income & 46 & 28 & 26 \\
\hline \multirow{3}{*}{ Denmark } & Native-born & 20 & 43 & 37 \\
\hline & Foreign-born & 29 & 39 & 32 \\
\hline & Foreign-born, lower-income & 42 & 36 & 22 \\
\hline \multirow{3}{*}{ France } & Native-born & 23 & 45 & 32 \\
\hline & Foreign-born & 41 & 31 & 28 \\
\hline & Foreign-born, lower-income & 43 & 30 & 27 \\
\hline \multirow[b]{2}{*}{ Germany } & Native-born & 9 & 64 & 28 \\
\hline & $\begin{array}{l}\text { Foreign-born } \\
\text { Foreign-born, lower-income }\end{array}$ & 35 & 45 & 20 \\
\hline \multirow{3}{*}{ Netherlands } & Native-born & 22 & 44 & 35 \\
\hline & Foreign-born & 39 & 33 & 28 \\
\hline & Foreign-born, lower-income & 45 & 32 & 22 \\
\hline \multirow{3}{*}{ Norway } & Native-born & 18 & 44 & 38 \\
\hline & Foreign-born & 26 & 35 & 38 \\
\hline & Foreign-born, lower-income & 36 & 33 & 31 \\
\hline \multirow{3}{*}{ Sweden } & Native-born & 11 & 55 & 34 \\
\hline & Foreign-born & 25 & 40 & 35 \\
\hline & Foreign-born, lower-income & 29 & 37 & 33 \\
\hline \multirow{3}{*}{ UK } & Native-born & 27 & 39 & 34 \\
\hline & Foreign-born & 22 & 41 & 37 \\
\hline & Foreign-born, lower-income & 26 & 38 & 36 \\
\hline \multirow{3}{*}{ USA } & Native-born & 7 & 61 & 32 \\
\hline & Foreign-born & 28 & 42 & 30 \\
\hline & Foreign-born, lower-income & 31 & 41 & 28 \\
\hline \multirow{3}{*}{ Switzerland } & Native-born & 5 & 58 & 36 \\
\hline & Foreign-born & 27 & 38 & 36 \\
\hline & Foreign-born, lower-income & 31 & 40 & 29 \\
\hline \multirow{3}{*}{ OECD average (1) } & "Native-born & 15 & 47 & 30 \\
\hline & Foreign-born & 28 & 35 & 28 \\
\hline & Foreign-born, lower-income & 37 & 36 & 27 \\
\hline
\end{tabular}

Note 1: The OECD average refers to the unweighted average of all countries included in the table.

Source: European Community Labour Force Survey 2009 and Current Population Survey March Supplement 2009 for the United States. 
96. Immigrants in Austria have a similar proportion of highly-educated as the native-born population. However, they are strongly overrepresented among the low-educated. $30 \%$ of all foreign-born and $44 \%$ of immigrants from lower income countries have not completed upper secondary education compared with only $13 \%$ of the native-born. The difference is particularly large among immigrants from lower-income countries. These are three times as likely to be low-educated as the native-born. Only Germany has a similarly strong overrepresentation of the former. However, as in other OECD countries, recent arrivals seem to be more educated than past immigrant cohorts. Among those who have arrived over the past decade, $23 \%$ are highly-educated.

97. The low average educational attainment of immigrants in Austria is particularly problematic since the Austrian labour market places strong emphasis on formal qualifications, as evidenced by a strong increase in the employment rate with education level (see OECD, 2009a). ${ }^{34}$ Overall, the employment rate for the highly-educated aged 25-64 is 30 percentage points higher than for the low-educated, above the OECD average of 26 percentage points.

98. However, the increase is much less pronounced for immigrants, who apparently have difficulties in having their education credentials equally well accepted as the native-born. Figure 9 shows the differences in employment rates between immigrants and native-born by education level. In general, these gaps tend to be larger for highly-qualified immigrants than for the low-educated. In Austria, as well as in Germany, France and Switzerland, this tendency is particularly pronounced. A more detailed breakdown by gender and country of origin is provided in Table A5 in the Annex. It shows that immigrant men with low education have a slightly higher employment rate than comparable native-born men. It is again the immigrants with qualifications from lower-income countries and women from lower-income countries who face the largest disadvantages.

Figure 9. Percentage-point differences in employment rates of foreign- and native-born, by educational level, aged 15-64 and not in education, 2008/2009 average

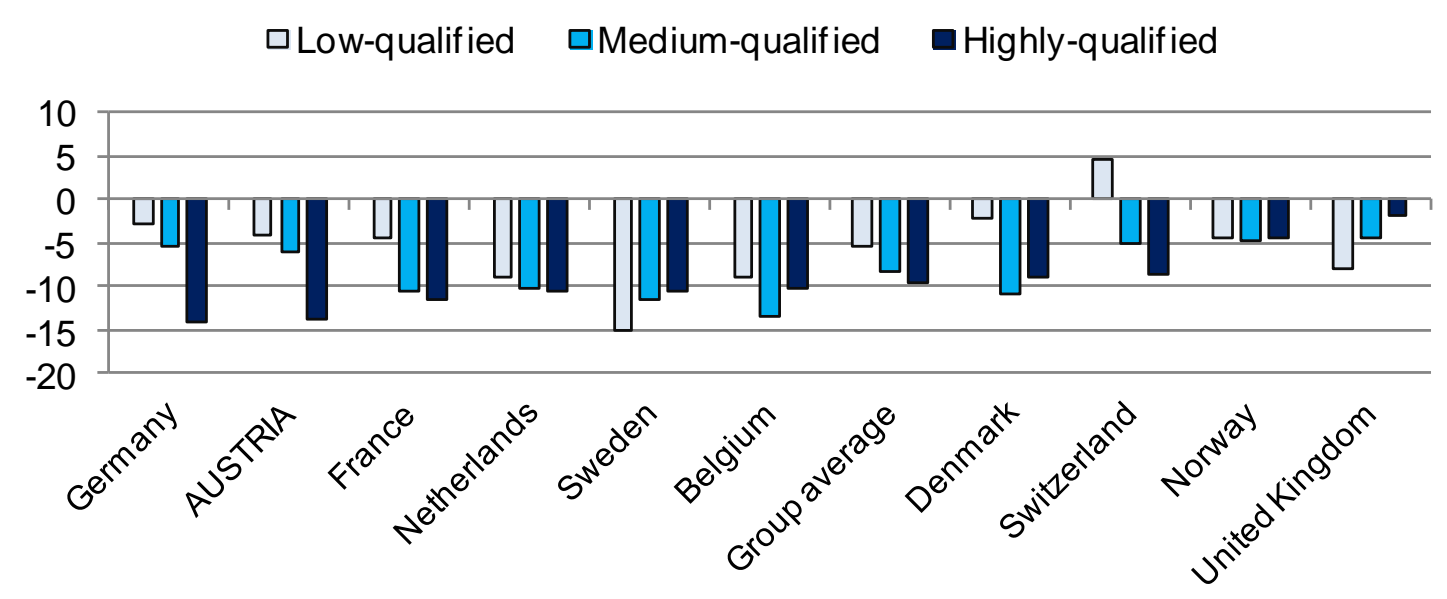

Note: The group average refers to the unweighted average of all countries included in this figure.

Source: European Community Labour Force Survey 2008/2009.

34 Formal qualifications are not only important in the labour market, but also in social life in Austria, where persons are commonly addressed by their academic titles. 
99. Even when they find employment, highly-educated immigrants in Austria have, compared with the native-born, a much lower probability of being in a job that matches their skills. While $70 \%$ of the highly-educated native-born are employed in highly-skilled jobs, this only holds for 55\% of the foreignborn (see Annex Table A6). Among immigrants from lower-income countries, only $40 \%$ of those who are highly-educated are actually working in a highly-skilled job. Among the countries in the comparison group, Austria records the largest percentage of highly-educated foreign-born from low-income countries working in low-skilled jobs, as well as the highest share of inactive persons from this group (along with the Netherlands).

100. Further analysis points to similar tendencies in occupational outcomes for the large group of medium-educated. One third of the native-born with upper and post-secondary education are working in jobs above their skill level, while only $7 \%$ are in low-skilled jobs. In contrast, almost one third of mediumqualified immigrants from lower-income countries work in low-skilled jobs. It hence appears that the native-born are more prone to being underqualified for their jobs, whereas immigrants from lower-income countries tend to be overqualified. Immigrants from higher-income countries have, once more, almost the same outcomes as the native-born. It is thus essentially immigrants from lower-income countries who find their credentials discounted on the Austrian labour market. ${ }^{35}$

101. One possible explanation for the high incidence of overqualification among the immigrants in Austria could be the fact that until recently, employment was required for many immigrants to maintain a secure residence status, obliging immigrants to take up any job, even one for which they were overqualified. In addition, the access of foreign nationals to both unemployment support and social assistance used to be restricted until the late 1990s. In 1990, for example, more than $90 \%$ of the registered unemployed nationals received either unemployment support or social assistance, compared with only $48 \%$ of foreigners (see Biffl, 1992). Finally, for those who needed a work permit (mainly recent arrivals), this used to be tied to a specific employer until recently. This hampered upward job mobility. ${ }^{36}$

\section{The value of foreign qualifications}

102. Another explanation for the above-mentioned disparities in the outcomes between native-born and immigrants with the same education level from lower-income countries could be that Austrian employers value less degrees which have been acquired in a foreign education system. Indeed, analysis of the probability to be in a highly-skilled job suggests that the country of origin of a higher degree is of considerable relevance for the labour market outcomes of immigrants in Austria (see Table 5). Compared with the native-born, the foreign-born with Austrian qualifications seem to be the least disadvantaged, followed by immigrants with degrees from other high-income countries. Immigrants who completed their education in a lower-income country, on the other hand, appear to have significantly lower probabilities, even after accounting for other factors such as duration of residence.

103. Those immigrants from lower-income countries who have their education formally recognised still experience a significant discount, but the differences in the probability to be in highly-skilled employment are reduced by 26 percentage points. This suggests that at least part of the devaluation might arise from employers' unfamiliarity with foreign qualifications (see also Gächter and Smoliner, 2010; Gächter, 2010).

35 For a comparison of the qualification structure of migrants in Austria, as well as their rates of over- and underqualification to that of migrants in other EU countries, see Huber et al. (2010).

36 A related factor was that, until the 1990s, the obligatory labour market test for some groups was generally not applied for employment in certain low-skilled occupations with labour shortages, notably construction and tourism. 
DELSA/ELSA/WD/SEM(2011)12

Table 5. Percentage-point differences in the probability of being in highly-skilled employment for highlyeducated persons aged 15-64 in Austria, by origin of the qualification, 2008

\begin{tabular}{l|c|c|c}
\hline Variables & (1) & (2) & (3) \\
\hline $\begin{array}{l}\text { Foreign-born } \\
\text { Highest education in Austria }\end{array}$ & $-25^{\star \star \star}$ & $-11^{\star \star}$ & $-11^{\star \star}$ \\
Highest education from abroad & & $-17^{\star \star \star}$ & $-17^{\star \star \star}$ \\
$\quad$ Highest education from high-income country & & $-45^{\star \star \star}$ & $-26^{\star \star}$ \\
$\quad \begin{array}{c}\text { Highest education from lower-income country } \\
\text { Highest education recognised }\end{array}$ & & & $-50^{\star \star \star}$ \\
Highest education not recognised & & & \\
(Reference group: native-born) & & & \\
\hline
\end{tabular}

Note: The figures show the differences between the children of immigrants and the children of natives. They correspond to marginal effects in a logistic regression, calculated at the sample means of the respective variables. The reference group is the native-born. *,

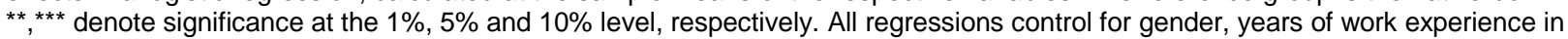
Austria, living in or outside of Vienna and number of children. Managers of small enterprises (up to 5 employees) and persons in fulltime education were excluded from the sample.

Source: Austrian Microcensus, ad-hoc module 2008 (data provided by Statistics Austria).

\section{Recognition of foreign qualifications}

104. Having one's foreign qualifications formally assessed and recognised is thus a key issue for labour market integration. In Austria, the outcome of the recognition procedure for academic qualifications can be either a so-called "nostrification" which provides an Austrian academic title but often requires revision of certain parts of the curriculum in an Austrian university, or a so-called "evaluation" which is non-binding, but places the foreign degree in the context of the Austrian education system without further requirements. ${ }^{37}$ The outcome of the process for non-academic, vocational qualifications is an "equivalence". In addition, for a range of academic and non-academic degrees from countries maintaining bilateral agreements with Austria, a formal "recognition" can be acquired through a fast-track procedure.

105. The Austrian system for recognition is thus rather complex, and this complexity is further reinforced by the fact that different bodies are in charge of the various types of credentials. The Ministry of Economy, Family and Youth, for instance, assesses the equivalence of vocational qualifications, while school-leaving diplomas fall under the domain of the Ministry for Education, Arts and Culture. The "nostrification" of academic credentials is conducted by universities, following common standards which are set by the Ministry for Science and Research. The Ministry of Health is, finally, responsible for the recognition of qualifications in certain healthcare professions. ${ }^{38}$

106. In the case of vocational qualifications, the assessment of "equivalence" tends to be difficult because Austria operates a dual education system, combining apprenticeship training at the workplace and in vocational schools, whereas several key origin countries rely on purely school-based programmes. As a

37 In total, in 2010, 1400 requests for evaluations were addressed to the National Academic Recognition Information Centre (ENIC-NARIC Austria).

38 EEA and Swiss nationals with qualifications in certain non-medical healthcare professions can benefit from a onestop-shop procedure that the Ministry of Health in order to obtain a license to exert their profession. NonEEA/Swiss nationals, however, need to address the government of the Austrian state in which they are residing to apply for "nostrification". As is also the case in "nostrification" procedures for nationals of other countries, they may have to participate in additional training courses, but places are limited and applicants often need to pass an entry exam including a German language test. 
result, vocational qualifications from such countries are often only partially recognised. Equivalence can be certified directly within two weeks, but if there is some doubt about the qualification, the applicant is required to pass either the practical part of the relevant Austrian apprenticeship examination or even the complete exam before the certificate is issued. For immigrants from these groups, an "evaluation" (as is possible for academic qualifications) would seem useful, but this is currently not possible.

107. In 2010, the Federal Ministry of Economy, Family and Youth processed roughly 30 requests for equivalence certificates per month, mostly filed by immigrants from the former Yugoslavia and from Germany. With Germany, in addition, there are bilateral agreements on a range of vocational qualifications for which direct recognition is guaranteed.

108. With respect to academic diploma, Austria maintains several bilateral agreements with most of the major origin countries to facilitate the recognition procedure, such as with Bosnia, Croatia and Serbia. Immigrants from these countries can address the Ministry of Science and Research for recognition of their degrees if the agreement covers their study discipline. If the set of personal and academic documents is complete, they can expect to be notified on the result within a few weeks. Given that about one third of the immigrants with foreign qualifications come from a country that maintains a bilateral agreement with Austria, the number of recognitions that are actually processed through this path is small - only 70 in 2010 .

109. However, as seen above, having one's foreign qualifications formally assessed seems to convey considerable benefits to migrants. One possible reason for the apparent strong link between the assessment and labour market outcomes is that the procedure reduces employers' uncertainty about the value of foreign qualifications. In addition, wage agreements fixing wages according to qualifications generally refer to Austrian qualifications and do not necessarily apply to foreign credentials. Furthermore, foreign qualifications which are not formally recognised do not conform generally to the classifications used by the Public Employment Service's digital registration system. In such cases, their holders are generally assigned the code "PO", which implies that compulsory education has not been completed.

110. A major shortcoming of the current framework is the lack of a one-stop centre which would be in charge of qualifications at all levels and domains. Immigrants have to rely on NGOs for guidance, and these are rarely available outside of the main cities. Only immigrants with academic degrees can seek advice at the ENIC-NARIC Austria under the auspices of the Ministry for Science and Research, which provides individual, non-binding assessments of diplomas, as well as advice on further steps to follow in seeking recognition of foreign qualifications.

111. Administrative fees for the recognition procedure are modest. They range from EUR 13 for vocational credentials to EUR 150-160 for academic degrees and regulated healthcare professions. Like the amount of fees, the duration of this procedure varies, from a few weeks in cases of existing bilateral agreements to several months or longer, in cases where applicants need to revise parts of the curriculum in the Austrian system.

112. About three-quarters of all migrants with post-secondary degrees have obtained these abroad (see Table 6). In spite of the above-mentioned link between recognition and labour market outcomes, the majority of these immigrants do not go through a recognition process. Only about $30 \%$ of immigrants who completed at least post-secondary education abroad stated in 2008 that they had applied for recognition of their qualifications. Out of these, the vast majority ultimately obtained it, with less than $10 \%$ of the requests being rejected. Among those who did not apply, when asked for the reason, about two thirds stated that they did not consider it necessary. It is not clear what is underlying this statement - that is, whether the employer recognised their qualifications without a formal recognition procedure, or whether they are simply not aware of the procedure and its accessibility for non-regulated professions. Given the 
apparent benefits which the recognition procedure seems to convey in Austria, these reasons for not applying for qualifications recognition should be subject to closer study.

Table 6. Achievement of a higher degree abroad and efforts to have it formally recognised in Austria for foreign-born with post-secondary education and above, aged 15-64, 2008

\begin{tabular}{|c|c|c|c|c|}
\hline Highest degree or qualification achieved: & \multicolumn{2}{|c|}{ Foreign-born in \% } & \multicolumn{2}{|c|}{$\begin{array}{c}\text { Foreign-born, from a lower- } \\
\text { income country, in } \%\end{array}$} \\
\hline $\begin{array}{l}\text { in Austria } \\
\text { Abroad, out of which }\end{array}$ & $\begin{array}{l}28 \\
72\end{array}$ & & $\begin{array}{l}24 \\
76\end{array}$ & \\
\hline $\begin{array}{l}\text { applied for recognition, out of which } \\
\text { degree was recognised } \\
\text { degree was not recognised } \\
\text { did not get the result yet } \\
\text { did not apply for recognition } \\
\text { was not necessary } \\
\text { other reason }\end{array}$ & 32 & $\begin{array}{c}(100) \\
88 \\
6 \\
6 \\
(100) \\
67 \\
33\end{array}$ & 29 & $\begin{array}{c}(100) \\
81 \\
9 \\
10 \\
(100) \\
62 \\
38\end{array}$ \\
\hline
\end{tabular}

Note: How to read the table: $72 \%$ of immigrants with post-secondary qualifications got their highest qualification abroad. Out of these, $32 \%$ applied for recognition. Among the latter, $88 \%$ succeeded.

Source: Austrian Microcensus, ad-hoc module 2008 (data provided by Statistics Austria).

113. Informal qualifications or practical work experience cannot be considered during the assessment procedure and are not subject to any formal accreditation. Indeed, non-formal qualifications have received little policy attention in Austria thus far and there is no comprehensive procedure for the accreditation of prior learning (APL) in place. In the state of Upper Austria, however, the Social Partners, in cooperation with the Public Employment Service, have launched a pilot project in 2007 that assesses non-formal and informal qualifications in a modular procedure. Through targeted complementary training measures, participants are individually trained for a skill level that corresponds to the Austrian apprenticeship examination in the respective profession. After successful completion of the programme, they are awarded a formal certificate of equivalence.

114. The public debate on the necessity of such measures has increased over the past ten years (see Österreichische Universitätskonferenz, 2009). Indeed, one would expect immigrants to benefit disproportionately from such measures, given that employers tend to be more uncertain about the qualifications and skills of immigrants who have obtained these in often very different contexts.

115. Finally, there are relatively few specific integration offers for highly-skilled migrants. Indeed, most available measures tend to focus mainly on lesser-skilled migrants and their children. ${ }^{39}$ However, in the framework of the recent "skilled worker initiative" (see Section IV), skilled and highly-skilled migrants have been targeted indirectly. In addition, there are a number of projects at the regional and local level, but these are generally small-scale.

39 Since the low-qualified are more frequently affected by unemployment, the focus of the Austrian Public Employment Service generally lies with low-qualified job-seekers. 
DELSA/ELSA/WD/SEM(2011)12

\section{Integration policy}

\section{Immigrants' participation in active labour market programmes}

116. Considering the low overall unemployment rate in Austria, spending on active labour market policy measures (ALMP) is relatively high compared with other OECD countries (see Duell et al., 2010). Currently, immigrants are not a specific target group for labour market policy in Austria, but the current version of the Federal Minister's labour market policy targets for the AMS provides for including immigrants as a separate target group, to be implemented from 2012 onwards. ${ }^{40}$

117. Indeed, in recent years there has been a growing effort to cater better for the needs of immigrants and their offspring, albeit mainly on a project-like basis, with multi-level financing and at the regional level. This has been partly integrated in the overall framework of the so-called "integration initiative" (see below). For example, the Territorial Employment Pacts (co-financed by the European Social Fund and the Austrian Federal Ministry of Labour, Social Affairs and Consumer Protection) have funded or co-funded several projects for specific migrant groups (immigrant offspring, immigrant women, and refugees). Unfortunately, none of these projects has been evaluated in a way that would permit to determine whether or not they are effective labour market integration tools. ${ }^{41}$ The AMS also enhanced its efforts to better reach immigrants, including by providing specific counselling for immigrants and information materials targeted at immigrants. In addition, the AMS has tried to increase the share of persons with an immigration background among AMS staff, among other, by favouring the hiring of persons who speak the main languages of immigrants. The Vienna AMS has implemented a comprehensive diversity management approach and provides, among other measures, special diversity training to its staff. Since 2007, it also obliges external course providers to participate in a two-day special "diversity course" which includes awareness-raising about discrimination mechanisms in the labour market.

118. Participants in active labour market policy measures are assigned to the individual courses by their AMS case workers. Most of the courses are organised by private companies. To date, there has been no comprehensive evaluation of the effect of the Austrian ALMPs on immigrants. ${ }^{42}$ Indeed, policy evaluation is poorly developed in Austria. Many "evaluations" content themselves with descriptive analysis. The "effect" is sometimes merely measured by taking the participants' opinions about the measure's usefulness, albeit this is often complemented by descriptive figures about transitions into employment.

119. Until recently, information on participation in active labour market policy measures has only been available on the basis of nationality. Better data are gradually becoming available as the AMS data now allow to identify not only current nationality but also naturalisation of immigrants and their offspring (see Box 1 above).

40 The Federal Minister for Labour, Social Affairs and Consumer Protection, in agreement with the Social Partners, publishes labour market policy goals to be implemented by the Public Employment Service. These goals set the framework for the long-term planning of the AMS to be translated into annual objectives, which will include immigrants as a specific target group from 2012 onwards.

41 A systematic and methodically rigorous evaluation should be based on a comparison of the ex post labour market outcomes of participants in a given measure with the outcomes of a comparison group with equal characteristics and equal ex ante labour market status but who has not participated.

42 In addition to evaluations of individual ALMP measures (e.g. Weber and Hofer, 2004a and 2004b), there have been two comprehensive evaluations of the Austrian ALMPs, by Lutz et al. (2005) and by Lechner et al. (2007). Neither of these looked at immigrants separately, although the latter study found that foreign nationals were underrepresented in most programmes. 
120. According to data from the AMS, persons with a migration background account for about $32 \%$ of persons registered as unemployed. Given this share, persons with a migration background appear to be roughly proportionally represented among participants in common active labour market programmes in Austria, (see Table 7). They are almost exclusively targeted by AMS-financed language courses which prepare for the labour market. ${ }^{43}$ The highest job placement rate is reached by workshop-based dual programmes, followed by "inplacement foundations" (see Box 4) and wage subsidies. All of these seem to be rather effective, if the overall percentage of low-educated unemployed in Austria who are in employment a year later is taken as a rough benchmark for the evaluation. ${ }^{44}$ The lowest percentage of persons with an immigrant background is found in inplacement foundations ("Implacement Stiftungen"), yet this measure seems to be a particularly beneficial programme for immigrants and their children.

121. In other OECD countries, wage subsidies have had a demonstrably strong effect on improving migrants' labour market integration, over and above the effects obtained for natives. Although the overall employment rates of persons who previously benefited from this measure (integration subsidy) are high in Austria as well, there is no difference in the placement rates between participants with and without a migration background.

Table 7. Participation in selected labour market programmes and employment rates three months after programme participation, 2009

\begin{tabular}{|c|c|c|c|c|}
\hline \multirow[b]{2}{*}{ Programme } & \multirow{2}{*}{$\begin{array}{c}\text { No. of } \\
\text { participants }\end{array}$} & \multirow{2}{*}{$\begin{array}{c}\text { Share with a } \\
\text { migration } \\
\text { background (in \%) }\end{array}$} & \multicolumn{2}{|c|}{$\begin{array}{c}\% \text { in employment three months } \\
\text { after completion of the } \\
\text { programme }\end{array}$} \\
\hline & & & $\begin{array}{c}\text { without migration } \\
\text { background }\end{array}$ & $\begin{array}{c}\text { with migration } \\
\text { background }\end{array}$ \\
\hline Implacement foundations & 5540 & 21 & 51 & 59 \\
\hline Language courses & 10442 & .. & .. & 22 \\
\hline Workshop-based dual programmes & 7880 & 49 & 73 & 67 \\
\hline Wage subsidies & 22768 & 37 & 62 & 60 \\
\hline Socio-economic enterprises & 16619 & 38 & 36 & 33 \\
\hline Non-profit employment projects & 6987 & 25 & 41 & 41 \\
\hline
\end{tabular}

Note: The figures for the share of "persons with a migration background" refer to the foreign-born and native-born with two immigrant parents.

Source: OECD Secretariat calculations on the basis of data provided by the Federal Ministry of Labour, Social Affairs and Consumer Protection and the Austrian Microcensus (data provided by Statistics Austria).

122. In recent years, there have been a number of measures to foster migrants' skills. In 2008, the federal government launched an initiative to enhance the pool of skilled labour in Austria (skilled labour initiative), and enhancing the skills of immigrants has been an important focus of this initiative. ${ }^{45}$ In 2010 , almost EUR 80 million were spent on training and other measures under this programme, $18 \%$ of which was spent on foreigners. A second programme with a specific focus on skilled labour in the metal industry

43 However, the job placement rates - that is, the percent in employment three months after having completed the language course - are low for this measure. Only one out of five participants is in employment three months after completion of the course.

44 Note that the difference in the time period may be less of a problem since several of the measures last for about six months to a year. However, it is not possible to have a rough idea of the long-term effects.

45 Although "persons with a migrant background" were a target group, unfortunately there is no information currently available regarding how many of them actually participated, and the effect which programme participation actually had on this group. 
had been launched in 2007 already (lasting until 2009). The available figures for foreigners $-21 \%$ of the EUR 77 million spent concerned foreigners - suggest that they have been well overrepresented. According to an internal analysis carried out by the BMASK, the share of participants with a migration background amounted to approximately one third in this programme. Indeed, in the integration efforts in Austria there has been a particular focus on occupations in which there is a current or expected future demand for skills, and there is some evidence that this has paid off (see Box 5).

\section{Box 5. Integrating immigrants into shortage occupations}

Skill shortages are a growing problem in Austria, in particular in some of the more dynamic regions. The government has therefore launched a number of important initiatives in this respect since 2008 to promote skilled employment for those not in employment. Although not directly targeted by most of these measures, immigrants are overrepresented in several of these. One of the industries where labour shortages are pronounced is the metal industry. To tackle the issue, the AMS launched a "skilled metal workers training campaign" in 2007 that aimed at doubling the number of skilled metal workers trained in AMS measures from previously 5000 to 10000 per year and was funded with EUR 133 million over a period of two years. About 20000 persons participated in the programme between 2007 and 2009 and about one fifth of these were foreign nationals. Indeed, immigrants were mentioned as a particular target group for this measure. Participants were either placed in apprenticeships that led to a final apprenticeship examination or participated in intensive training courses for skilled workers that build upon existing competencies. The AMS has, moreover, launched a "regional skilled worker programme" in 2008 that allows to adjust the quantity and quality of "skilled worker training" to the needs of regional labour markets (BMASK, 2010b).

The AMS of Upper Austria, for instance, has implemented the "skilled metal workers training campaign" in a large-scale programme since 2008 that has a modular structure and includes several stages of language - and vocational training. To prepare for the final apprenticeship examination, participants gain hands-on experience in machine parks that were especially set up for this purpose. Participants are paid a monthly allowance that corresponds to $70 \%$ of the former net income (for those with previous employment). The programme can take up to 18 months but because of the modular structure, participants are free to skip certain modules or to finish without taking part in the final examination. From the roughly 600 persons on average that have started the programme each year, $40 \%$ complete the entire course. Immigrants make up for almost $40 \%$ among all participants and even half of the participating women.

The budget for this qualification programme amounted to EUR 13 million in 2010, which represented $10 \%$ of the total budget of the AMS Upper Austria and corresponded to over EUR 20000 per participant. A first evaluation in the second half of 2009 suggested that the measure was rather successful, as $59 \%$ of the participants were in skilled employment three months after completion of the programme, despite the economic crisis which hit the Austrian labour market at the same time. It is estimated that more than two thirds of the participants actually integrate into the steel industry. The figures are broadly the same for immigrants.

Another rather successful tool for the targeted training of unemployed for shortage occupations is the so-called "inplacement foundations", introduced in 2002. One week after completion of the programme, more than half of the participants are in employment. This figure even rises to almost $70 \%$ one year after the end of the measure (BMASK, 2010a) and the available evidence in Table 7 suggests that it is particularly beneficial for immigrants, albeit they tend to be significantly underrepresented. Funded and organised jointly by the AMS and employers, inplacement foundations train participants specifically for vacancies that enterprises cannot fill from the regular labour supply. Employers participate in the recruitment of participants, as well as in the development of a tailor-made training plan. During the programme that usually takes between one and three years, they contribute to the monthly training costs (in Styria, for instance, they contribute an amount of about EUR 400 per month) and provide candidates with internship opportunities and the prospect of employment in the company.

Given its success, the programme has been expanded in recent years. The AMS more than doubled the resources allocated to all sorts of labour foundations between 2000 and 2009, the bulk of which concerned this particular measure (BMASK, 2010a). ${ }^{46}$ Costs per participant in labour foundations in general amounted to EUR 10600 per person in 2009. Among the main sectors applying the concept of "inplacement foundations" is the elderly- and health-care sector.

46 Apart from "inplacement foundations", the AMS maintains "outplacement foundations" and other measures with similar concepts which are all subsumed under the title of labour foundations. 


\section{The integration offers for new arrivals and language training}

123. In contrast to other OECD countries that have participated in the Jobs for Immigrants reviews such as Norway, Denmark or Sweden, Austria does not have an introduction programme, although some states and communities have established local programmes on a voluntary basis for some specific groups. ${ }^{47}$ The introduction activities proposed to migrants at the federal level are related to the obligation of migrants to have some basic mastery of German in the framework of the integration agreement (see above).

124. To help migrants fulfil these obligations, the Austrian integration fund co-finances language courses. These target a basic level of German language mastery and not labour market integration. Indeed, they aim at passing the requirements of the integration agreement which family migrants and a number of other groups from non-EEA countries who arrived after 1 January 2006 need to sign (see above). Under certain circumstances, the Austrian integration fund provides co-financing of up to EUR 375 for alphabetisation courses, and an additional EUR 750 co-financing for the standard courses (which last 300 hours), provided that the level of A2 in the common European reference framework for languages has been reached.

125. Far more important in terms of budget expenditure are the offers by the AMS. In 2008, EUR 23 million of language training in German were provided by the AMS. In 2009 and 2010, the available funds for language training were increased further in the framework of the so-called "integration initiative" (Integrationsoffensive) for jobseekers registered at the AMS.$^{48}$ More than EUR 38 million were spent in this context during the first ten months of 2009 alone. ${ }^{49}$ The courses are available in three levels, depending on the prior German-language knowledge and qualification level of the participant. In the first ten months of 2009, more than 15000 persons participated in language training through this channel, and the budgeted number of participants has been 21 500. In 2009, the average cost per participant and day was about EUR 30, a strong increase over the EUR 19 in 2008. ${ }^{50}$

126. There is also the possibility to provide the language training as vocational-specific training onthe-job. In other OECD countries, this has often been a rather effective - albeit expensive - tool for labour market integration; to which degree this is also the case in Austria is not known. Integrated packages with language tuition and vocation-specific training on-the-job only account for a relatively small part - about $5 \%$ - of all language training provided by the AMS. Nevertheless, language courses are often combined

47 The city of Vienna, for instance, has launched a coaching programme for new arrivals in 2008. The programme focuses on facilitating access to language courses, explains the integration agreement and refers new arrivals to counseling centres that provide assistance with the recognition of foreign qualifications and labour market entry in general.

48 The language training by the AMS is available to all registered unemployed independent of whether or not they obtained unemployment benefits or other social security payments. In contrast to many other OECD countries, in principle all migrants not in employment could thus benefit from this measure, even those who have no work experience in Austria.

49 Data for the full year of 2009 and for 2010 are not yet available.

50 The cost per participant hour is generally a good proxy measure for the quality of the training. Investment here varies widely, from less than EUR 3 per participant per hour for standard language courses in Germany to more than EUR 10 in Denmark. Assuming that the typical course is between four to five hours per day, Austria thus seems to be somewhere in the middle range. The average cost per participant over the whole training course in Austria was more than EUR 2200 in 2009. 
with subsequent (further) qualification or vocational training, where both are organised and monitored as separate measures but still form a comprehensive package. ${ }^{51}$

127. In addition to the integration courses and the AMS-provided language training, there are also a number of local offers in place. Little is known about their scale and scope, but figures for Vienna suggest that these play a much smaller role than the first two. The language courses which are provided by the different actors - AMS, Integration Fund and local authorities - are not co-ordinated, in spite of the fact that most of them broadly aim at the same level of language mastery (that is, generally A2-level).

128. In spite of the significant investment involved for the public purse, there has been no comprehensive evaluation of the language training thus far in Austria. The available information is shown in Table 7 above, indicating that on average only about one out of five participants are in employment three months after having completed the course. However, this rather low figure should be interpreted with caution, since many of the participants may have been quite far from the labour market and an additional $20 \%$ are in further qualification measures. Nevertheless, even one year after having participated in a language course by the AMS, less than $35 \%$ are in employment (a further $12 \%$ are still in qualification measures).

129. Another indication of the effectiveness of the courses is the association between past course participation and current labour market outcomes that is possible with the 2008 migration module in the Austrian Microcensus. This analysis also shows no discernible association between prior attendance at a language course and current labour market status, even after controlling for a number of factors such as country-of-origin, educational attainment and duration of residence in Austria.

130. This, of course, does not mean that language training is not effective. Indeed, it is likely that there is some negative selection in language-course attendance, since those with good mastery of the German language will not need such training which, in addition, generally only targets low levels of language mastery.

\section{The labour market integration of the children of immigrants}

131. Migrants themselves will always tend to retain characteristics related to their foreign origin which may hamper the integration process. The success or failure of the children of migrants raised and educated in the country of residence is thus often seen as the ultimate "benchmark" of integration (Card, 2004). The integration of the children of immigrants is of particular importance in Austria as their number is growing rapidly. The share of native-born children of immigrants in the population aged 15-24 will more than double by 2020 , from currently $7 \%$ to $15 \%$. As seen above, labour market outcomes are strongly influenced by educational attainment in all OECD countries, and the association is particularly strong in Austria. The education outcomes of the children of immigrants and the institutional context of education thus have be analysed first, before looking at the functioning of the labour market itself.

\section{Education outcomes in international comparison}

132. Results from the 2009 OECD Programme for International Student Assessment (PISA) show that the children of immigrants in Austria have much lower educational outcomes than the children of nativeborn (see Table 8; for additional information on the 2009 PISA survey see OECD, 2010c). Only Belgium and Denmark recorded larger differences in the reading literacy between native-born children of

51 Especially workshop-based dual programmes and complementing (preparatory) measures such as production schools integrate vocational training and language support measures. In these measures, youth with a migration background have a considerable share among the participants. 
immigrants and the children of natives. With respect to young immigrants, Austria records the largest gap in reading scores of all countries in the comparison group. Table 8 also shows significant gender differences - the gaps tend to be larger for young women with a migration background than for men, in contrast to what is observed in most other OECD countries where the gaps tend to be smaller for women.

133. Empirical studies from many countries show some tendency towards intergenerational transmission of human capital. Immigrant parents are less educated on average than their native-born peers, although the differences in Austria, especially for the immigrant parents of native-born children, are not as large as in most other countries in the comparison group. Controlling for differences in the socioeconomic background thus reduces the differences between children of immigrants and children of natives (by about one third), but they still remain large in international comparison, in particular for young women with an immigrant background.

134. Further analysis with the PISA data shows that age at immigration has a significant, albeit small influence on PISA outcomes - each additional year that young immigrants spend in the origin country is associated with a decline of the score of more than 2 points. Likewise, Bock-Schappelwein et al. (2009) report that the age of the time of migration to Austria is negatively correlated with the qualification level which young migrants reach. Insofar as the restrictive policies for family migration that have been introduced in recent years retard the arrival of young immigrant children into Austria, for families in which this is an issue, they may thus come at a cost in terms of lower integration outcomes.

\section{Early childhood education}

135. Empirical findings from a number of OECD countries suggest that early childhood education and care (ECEC) can have an important impact on the educational outcomes of children from a disfavoured socio-economic background (see OECD, 2009b for an overview). One possible reason for the poor performance of children of immigrants in Austria may thus be the fact that ECEC is relatively poorly developed in Austria (see Bacher, 2003; OECD, 2009b). Participation in ECEC begins rather late, in general at the age of 3 . The overall enrolment rates in Austria (excluding Styria, for which no data are available) have risen from about $67 \%$ in 2004 to $80 \%$ in 2009; the figures are slightly lower (about five percentage points in either year) for the children with a foreign nationality. ${ }^{52}$ However, there are important differences, both across regions and among nationality groups. In Vienna, for example, children at this age who have a Turkish or ex-Yugoslavian nationality have only an enrolment rate of 57\%, compared with more than $84 \%$ for Austrians. The former are also the only group which does not seem to have benefited from the recent improvements in coverage of ECEC in Austria. At the age of five, however, enrolment rates are around $90 \%$ and above in all regions and for nationals and foreigners alike.

52 Data from years prior to 2004 are not available, but there is little doubt that there has been a strong improvement since the late 1990s, the time when the 2009 PISA-cohort was in the ECEC age-range. The current poor performance may thus be at least partly the result of the low ECEC coverage at that time. 
DELSA/ELSA/WD/SEM(2011)12

Table 8. PISA 2009 results for the children of immigrants, point differences in reading scores compared with the children of natives

\begin{tabular}{|c|c|c|c|c|c|c|c|c|c|c|c|c|c|c|}
\hline & \multicolumn{6}{|c|}{ Unadjusted } & \multicolumn{6}{|c|}{ Adjusted } & \multicolumn{2}{|c|}{$\begin{array}{c}\text { Differences in the numbers of years of } \\
\text { highest parental schooling compared with } \\
\text { the children of natives }\end{array}$} \\
\hline & \multicolumn{3}{|c|}{ Native-born children of immigrants } & \multicolumn{3}{|c|}{ Young immigrants } & \multicolumn{3}{|c|}{ Native-born children of immigrants } & \multicolumn{3}{|c|}{ Young immigrants } & $\begin{array}{c}\text { Native-born children of } \\
\text { immigrants }\end{array}$ & Young immigrants \\
\hline & Men & Women & Total & Men & Women & Total & Men & Women & Total & Men & Women & Total & Total & Total \\
\hline Australia & -20 & -10 & -16 & -7 & 1 & -3 & -24 & -12 & -19 & -7 & 2 & -3 & 0.0 & 0.5 \\
\hline AUSTRIA & 51 & 58 & 55 & 77 & 118 & 98 & 23 & 37 & 30 & 49 & 87 & 69 & -1.2 & -1.9 \\
\hline Belgium & 69 & 60 & 65 & 81 & 55 & 71 & 39 & 35 & 37 & 44 & 37 & 42 & -1.5 & -1.1 \\
\hline Canada & 8 & 1 & 5 & 7 & 7 & 8 & -2 & -7 & -4 & 5 & 7 & 7 & -0.4 & 0.6 \\
\hline Denmark & 57 & 57 & 56 & 78 & 81 & 79 & 34 & 34 & 32 & 56 & 55 & 55 & -1.8 & -0.8 \\
\hline France & 70 & 40 & 55 & 79 & 71 & 77 & 39 & 13 & 24 & 50 & 48 & 51 & -1.8 & -1.4 \\
\hline Germany & 56 & 52 & 54 & 54 & 70 & 61 & 31 & 33 & 31 & 40 & 46 & 42 & -2.0 & -0.7 \\
\hline Greece & 36 & 24 & 33 & 74 & 69 & 69 & 20 & 13 & 20 & 37 & 39 & 36 & 0.2 & -0.6 \\
\hline Ireland & 20 & -27 & -6 & 50 & 15 & 36 & 35 & -19 & 4 & 48 & 26 & 39 & -0.2 & 0.9 \\
\hline Italy & 42 & 43 & 45 & 81 & 80 & 81 & 21 & 22 & 23 & 52 & 55 & 54 & -0.2 & 0.0 \\
\hline Luxembourg & 60 & 53 & 56 & 50 & 43 & 47 & 28 & 19 & 22 & 27 & 20 & 24 & -3.4 & -2.0 \\
\hline Netherlands & 43 & 51 & 46 & 48 & 39 & 44 & 17 & 26 & 21 & 18 & -1 & 7 & -2.4 & -2.3 \\
\hline New Zealand & 27 & 28 & 28 & 2 & 9 & 6 & 6 & 13 & 10 & 11 & 18 & 15 & 0.1 & 0.8 \\
\hline Norway & 39 & 51 & 45 & 55 & 68 & 60 & 26 & 35 & 31 & 33 & 41 & 37 & -0.7 & -0.9 \\
\hline Portugal & 21 & 21 & 16 & 54 & 16 & 36 & 1 & 20 & 9 & 47 & 12 & 29 & 1.1 & 2.2 \\
\hline Spain & 21 & 32 & 26 & 63 & 62 & 62 & 14 & 26 & 20 & 44 & 45 & 44 & -0.1 & 0.0 \\
\hline Sweden & 49 & 60 & 53 & 91 & 94 & 91 & 29 & 34 & 31 & 68 & 54 & 61 & -0.7 & -1.8 \\
\hline Switzerland & 41 & 43 & 42 & 59 & 59 & 58 & 21 & 22 & 21 & 41 & 43 & 42 & -1.7 & -0.9 \\
\hline United Kingdom & 20 & -8 & 7 & 45 & 38 & 41 & 23 & -3 & 11 & 31 & 29 & 29 & -0.3 & -0.3 \\
\hline United States & 25 & 20 & 22 & 30 & 14 & 21 & 1 & -1 & 0 & 4 & -11 & -5 & -2.1 & -1.9 \\
\hline OECD & 28 & 22 & 25 & 37 & 30 & 33 & 8 & 6 & $\overline{77}$ & \begin{tabular}{l|l|}
18 \\
\end{tabular} & 112 & 14 & -1.5 & -0.9 \\
\hline
\end{tabular}

Note: The figures show the points differences in the PISA 2009 scores for reading literacy between children of natives on the one hand and (native- and foreign-born) children of immigrants on the other. "Young immigrants" are students who are foreign-born and whose parents were also born in another country. "Native-born children of immigrants" refers to native-born students whose both parents were foreign-born. "Unadjusted" refers to the points' differences in the raw scores, "adjusted" to the differences after controlling for the socio-economic background of students. The socio-economic background was created on the basis of the following variables: the International Socio-Economic Index of Occupational Status (ISEI), the highest level of education of the student's parents, the index of family wealth, the index of home educational resources and the index of possessions related to "classical culture" in the family home. OECD is the average of all countries for which full data are available. Negative values mean that children of immigrants have better results than children of natives. Differences which are not statistically different from zero are in italics.

Source: OECD, PISA database 2009.

136. The first year of early childhood education thus seems to be the most critical one, in particular for the most disadvantaged migrant groups. The reasons for the low enrolment are unclear, but in areas where places are limited, preference is given to older children and to children with working mothers. Since immigrant mothers - in particular those from Turkey - are less likely to be in employment than their native-born counterparts, their children have thus less chances to be able to participate in ECEC, in spite of the fact that they would particularly benefit from it.

137. Since 2005, all 4-5 year olds are screened for language deficits and can participate in language support measures if a need is detected. The Federal Ministry of the Interior has developed a national curriculum for early language learning, and several federal states have launched their own initiatives in this field. In 2009, a free but compulsory year of kindergarten has been introduced nationwide to secure that all children are captured by these supportive measures. An evaluation of early language support, however, suggests that the training period of one year may be insufficient and that language screening at the age of three, such as practiced e.g. in Denmark, tends to be more effective (Breit, 2007; see also OECD, 2009b). Moreover, it appears that these reforms have led to a shift of resources that comes at the expense of measures targeting the 2 to 5 year-olds in some states.

\section{Children of immigrants in the Austrian education system}

138. In contrast to ECEC, which is a competence of the local authorities, schooling is a state competence. The official Austrian school statistics provide two alternative means of identifying children with a migration background. These are nationality and the language spoken at home. Given that the majority $(60 \%)$ of the native-born children of immigrants below the age of 15 have Austrian nationality, the preferable proxy for migration background in the Austrian school statistics seems to be the language 
spoken with the parents at home, which is registered for every child. In 2009, almost one fifth of the overall student population in Austria spoke a first language different from German. ${ }^{53}$ In Vienna, their share amounted to more than one third, while other federal states recorded less than $10 \%$. The most frequent languages are Turkish, Bosnian, Serbian and Croatian. However, this is an imprecise indicator as well, since many children of immigrant parents speak German at home. It is estimated that this proxy misses out at least $5 \%$ of children with a Turkish and $13 \%$ with a Yugoslav background (Herzog-Punzenberger, 2007).

139. A key feature of the Austrian education system is its selectivity. Schooling is compulsory between the age of 6 and 15, and over the course of these nine years, students are sorted twice. The first step of selection - between a higher and lower track - takes place at the age of ten (i.e. after four years), which is earlier than in other OECD countries (the OECD average is 14 years). The parents' educational background and professional status have been found to have a strong impact on the outcomes of this first selection process that is based on grades, parents' preferences and teacher recommendation (Bacher, 2003).

140. High-performing students proceed to the higher track of lower secondary school, where students with a first language different from German are underrepresented, albeit not by much. They account for $15 \%$ in these schools compared with $20 \%$ in the overall age group. Accordingly, they are slightly overrepresented in the lower track, especially in Vienna where they make up almost two thirds of students in this track (that is, given their share in the population they are twice as likely to find themselves in this track). In recent years, several comprehensive "new middle schools" have been established that skip the first step of selection and offer comprehensive schooling until the age of 14 (see OECD, 2010b). Although not yet widely spread, these schools seem to attract immigrant offspring over-proportionally. Children of immigrants make up $28 \%$ of the student population in these schools. ${ }^{54}$

141. At the age of 14, students are sorted for the second time, either into vocational or academic upper secondary tracks. Only one quarter of all students choose the second option that prepares for higher education and leads to the Matura (university-entrance diploma) after four years of general upper secondary education. The remainder follows some sort of vocational education and training (VET). This is one of the highest shares in the OECD and demonstrates the prominent role of VET in the Austrian education system, which in turn is related to the predominance of medium-level qualifications in the Austrian working-age population (see OECD, 2010b). Half of the VET students follow a dual apprenticeship training (Lehre), combining practical training on the job with part-time vocational schooling. Another $40 \%$ enrol in higher vocational and technical colleges that award the Matura along with a professional qualification after five years of joint general and vocational education and grant access to higher education. The remainder follows purely school-based vocational programmes.

142. While vocational students in other OECD countries such as Germany, Denmark, the Netherlands and Switzerland transit directly from lower secondary school into apprenticeships, many Austrian students usually have to spend a bridging year in between because they need to wait until they turn 15 to be allowed to work. So-called polytechnic schools offer one-year training in basic vocational skills and career guidance and are open to all students, irrespective of previous performance. About a fifth of a student cohort passes through such a school. Well-performing students, however, mainly spend their bridge year in more prestigious vocational schools and colleges that maintain admission criteria. Low-performing students, hence tend to be concentrated in the non-selective polytechnics, especially in urban areas, where alternatives are broad. Although the transition rate into regular VET training amounts to $90 \%$, drop-out

53 For the sake of convenience, in the subsequent analysis based on schooling statistics, children with a first language other than German are subsequently referred to as "children of immigrants".

54 Unless noted otherwise, all figures in this and this sub-section are extracted from the Austrian School Statistics, Statistics Austria 2009/2010. 
rates are higher for those coming from polytechnic schools than for students from other school types. ${ }^{55}$ Children of immigrants are more likely to spend a year at polytechnic school than children with German as a first language, especially in Vienna where they represent $60 \%$ of the polytechnic students.

143. The two steps of selection in the Austrian education system appear to be key determinants of immigrant offspring's educational attainment. Children of immigrants who chose the higher track after the first four years of primary school (that is the lower level of academic secondary school) have broadly similar subsequent education pathways as children of natives (see Table 9). In contrast, those who were sorted into the lower track (that is lower secondary school) have different education pathways which generally lead to lower outcomes. They are 13 percentage points less likely than the native German speakers to proceed to the (rather prestigious) higher vocational college, but 13 percentage points more likely not to transit into any sort of upper secondary education at all. Due to a lack of data and evaluation, it is unknown whether this gap is attributable to lower grades or previous performance, or other factors notably those linked with a migration background. ${ }^{56}$

144. Even for those who remain in education after this second step of selection, school drop-out remains a considerable problem. This is a known shortcoming of the Austrian school system (see OECD, 2010b and Steiner, 2009) which nevertheless affects children of immigrants overproportionally. Almost $60 \%$ of children with a first language other than German who entered vocational school do not complete it, compared with $47 \%$ of the children of natives. One third drops out of the academic upper secondary track compared with one fifth of native German-speakers. The difference in drop-out rates is most striking for students of higher vocational colleges. Half of children of immigrants in this track do not complete it, which is twice as many as among children without a migration background. ${ }^{57}$ This suggests that children of immigrants would benefit more than proportionally from policy measures designed to cut drop-out rates.

55 Half of the students in vocational schools and more than two thirds of the students in vocational colleges finish upper secondary education successfully, while this is only the case for 40 and 30\%, respectively, of former polytechnic students.

56 In any case, children of immigrants are twice as likely as the children of natives to be already 15 years old upon completion of lower secondary education, in general because they repeated a year. This means that they fulfil the required nine years of compulsory schooling after the 8th grade and are free to leave the school system at this early stage.

57 However, these figures need to be interpreted with caution. The high drop-out rates in vocational schools and colleges are partly attributable to the common practice of spending the ninth year of compulsory schooling in one of these institutions before taking-up an apprenticeship at the age of 15. Moreover, these figures do not specify the reasons for drop-outs. The latter might thus represent actual school leaving, or stem from a mere change of school type. 
Table 9. Percentage-point difference in the transition rate of 14-year olds from lower to upper secondary education, students with a foreign first language, compared with students whose first language is German, 2009/2010

\begin{tabular}{|c|c|c|c|}
\hline & $\begin{array}{l}\text { Children of } \\
\text { natives }\end{array}$ & $\begin{array}{l}\text { Children of } \\
\text { immigrants }\end{array}$ & $\begin{array}{c}\text { \%-point difference in the transition } \\
\text { rate of the children of immigrants, } \\
\text { compared with the children of } \\
\text { natives }\end{array}$ \\
\hline \multicolumn{4}{|l|}{$\begin{array}{l}\begin{array}{l}\text { Transition from lower secondary school } \\
\text { to... }\end{array} \\
\text { to }\end{array}$} \\
\hline Academic secondary school (higher level) & 6.8 & 5.2 & -1.6 \\
\hline Higher vocational college & 31.8 & 18.9 & -12.9 \\
\hline Vocational School & 22.1 & 17.8 & -4.3 \\
\hline Apprenticeship & 7.2 & 8.7 & 1.5 \\
\hline Polytechnic school & 26.4 & 30.6 & 4.2 \\
\hline No transition & 4.3 & 13.9 & 9.6 \\
\hline \multicolumn{4}{|c|}{$\begin{array}{l}\text { Transition from academic secondary school (lower level) } \\
\text { to... }\end{array}$} \\
\hline Academic secondary school (higher level) & 59.8 & 61.9 & 2.1 \\
\hline Higher vocational college & 32.4 & 26.7 & -5.7 \\
\hline Vocational School & 1.7 & 1.2 & -0.5 \\
\hline Apprenticeship & 0.8 & 0.5 & -0.3 \\
\hline Polytechnic school & 0.5 & 0.5 & 0.0 \\
\hline No transition & 1 & 2.6 & 1.6 \\
\hline
\end{tabular}

Note 1: "Children of immigrants" are defined as children with a first language other than German. Transition takes place after completion of the 8th grade of compulsory schooling. "No transition" applies to students who left the education system or for whom information is missing. Corresponding ISCED-levels: polytechnic school: 3C; vocational school / apprenticeship: 3B, higher vocational college: 3A/4A; academic secondary school (higher level): 3 A. Percentages do not add up to 100 as figures for transition into special needs schools, as well as repeaters of the eighth grade are not included in this table. A negative difference means that children of immigrants are less likely to transit into this school type, compared with children of natives.

Note 2: Most students attend a polytechnic school or first year of vocational school for one year before starting an apprenticeship. Considering this, in total one-third of an age cohort opt for apprenticeship training.

Source: Austrian School Statistics 2010, provided by Statistics Austria.

145. As a result of this early school leaving, at the age of $20-29$, about $20 \%$ of native-born immigrant offspring find themselves among the low-educated who are not in education, three times more than the children of native-born. Offspring of Turkish origin are particularly affected, as about one out of three in this age-group has not completed upper secondary education. As shown in Table 10, the lower average level of mother's education explains half the gap in the probability to have left the education system without an upper secondary degree for the children of immigrants. 
Table 10. Percentage-point difference for the probability to leave the education system without an upper secondary degree, children of immigrants vs. children of native-born, aged 15-34, by gender 2009

\begin{tabular}{|l|c|c|c|}
\hline & Model 1 & Model 2 & Model 3 \\
\hline Native-born children of immigrants & $15^{\star * *}$ & $9^{* * *}$ & $9^{* * *}$ \\
Young immigrants & $17^{* \star *}$ & $12^{* * *}$ & $12^{* * *}$ \\
\hline \hline Control variables & & & \\
Mother's education & & $x$ & $\mathrm{X}$ \\
Age & & & $\mathrm{X}$ \\
Vienna & & & $\mathrm{X}$ \\
Number of children & & $\mathrm{X}$ \\
Marital status & & $\mathrm{X}$ \\
Gender & & & \\
\hline
\end{tabular}

Note: The figures show the differences between the children of immigrants and the children of natives. They correspond to marginal effects in a logistic regression, calculated at the sample means of the respective variables. The reference group is the native-born. ${ }^{*}$, ${ }^{* *},{ }^{* * *}$ denote significance at the $1 \%, 5 \%$ and $10 \%$ level, respectively.

Source: Austrian Microcensus, ad-hoc module 2009 (data provided by Statistics Austria).

\section{Policy measures to improve educational outcomes of the children of immigrants}

146. In Austria, basic German language training, as well as so-called "mother-tongue" instruction, have been relatively established in schools since the early 1970s; the latter mainly aimed at preparing the children of "guestworkers" for the eventual return to their countries of origin, rather than for long-term integration into Austrian society. This concept changed in 1992, when German language training and "mother-tongue" instruction were formalised in Austrian law as part of a more global commitment to diversity in the education system (see OECD, 2009b).

147. The scale of "mother-tongue" instruction in Austria seems to be still rather extensive nowadays, in spite of a lack of solid empirical evidence that this is an effective integration tool (see the discussion in OECD, 2008a, Chapter 4). Courses are provided in 18 different languages, but $80 \%$ of the students are either learning Turkish or Bosnian/Croatian/Serbian. In 2008/2009, almost 30000 students participated in this measure and were taught by roughly 360 teachers. About half of these students and teachers were concentrated in Vienna.

148. With respect to German language training, Austria maintains two different streams. Students with significant deficits in German can be classified as non-regular students, which means that their performance is not assessed and that they cannot fail a grade. ${ }^{58}$ These students generally receive remedial German language training over a period of 12 months, which can be prolonged for another year (see OECD, 2009b). However, to be established, these courses require a minimum number of eight participants. In practice, this hampers access to this offer for students in schools and regions with a low concentration of recently arrived immigrant offspring. Schools with non-regular students receive earmarked funding directly from the federal government to provide them with up to 12 hours of German language training per week. ${ }^{59}$

58 In 2009/2010, about 20000 students held this status.

59 Since 2009, budgets for this purpose have been increased for schools with a high share of non-regular students. 
149. Next to German language training for non-regular students, there is a second stream of training offers in German as a "second language" for regular students. ${ }^{60}$ In contrast to the courses for non-regular students, these are administered at state level. In 2001, the responsibility for language support budgets with respect to training in German as a "second language" for regular students, as well as "mother-tongue" instruction was shifted from the federal government to the states. The latter have since funded language training from residual resources that remain after accounting for the overall regular teaching activities. Although the government has included a recommendation to extend language training measures in school (both in "mother-tongue" instruction and German as a "second language "for regular students), the states are not bound to invest into this and can use their residual budgets for other measures if they wish to do so. Indeed, it appears that the 2001 shift of budget administration triggered a sharp decline in the resources allocated for language support measures in some states and increased heterogeneity of language support for immigrant offspring across Austria. The federal administration lacks information on language offers on the language training for regular students, including on their set-up, efficiency and allocated budgets.

150. A growing number of students with a "first language" other than German are native-born, have Austrian citizenship and are rather unlikely to return to their parents "country of origin. The prevailing emphasis on "mother-tongue" instruction in the Austrian context is thus questionable, especially given the unstable funding for language support measures in general, where investment in "mother-tongue" instruction may come at the expense of German language support measures. ${ }^{61}$

151. Although education of the children of immigrants is emphasised as an important field of policy intervention in the National Integration Plan of 2009, no concrete actions at the federal level have followed thus far. There are, however, some measures related to this at state-, municipal- and school-level. The city of Vienna, for example, maintains an intensive language support programme for newly-arrived students (see OECD, 2009b).

\section{School-to-work transition}

152. Some limited data on the school-to-work transition is available from a 2009 ad-hoc module in the Austrian Microcensus. These show that immigrant offspring have a much more difficult school-to-work transition than their peers without a migration background. About $20 \%$ of the 15 to 34 year-olds not in education have never worked compared with only $7 \%$ of the children of native-born. Among those who have been employed at least once, $11 \%$ of the native-born children of immigrants had already found their first job before they completed education compared with $16 \%$ of the children of natives. For those who start or continue to search for a job after having finished education, school-to-work transition takes 4 months longer than for the children of native-born (19 months vs. 15 months).

60 Indeed, one may question the term "German as a second language" in a context in which a large part of the children concerned are born in Austria and have Austrian citizenship.

61 This is not to say that such education may not provide benefits for the children involved, but given the limited resources available and the ultimate objective of a better integration into the Austrian labour market and society, the resources would probably be more effectively invested in German language training. Some of the funds for "mother-tongue" education could also be invested into inter-cultural offers for all children, to enhance mutual understanding between children of immigrants and children of natives. A first step in this direction has been taken, as the Federal Ministry for Education has recently developed a curriculum for teacher training in "linguistic diversity and intercultural education". 
153. Immigrant offspring who manage to find a first job mainly transit into medium-skilled employment, about the same as for the children of natives. About $8 \%$ find a first job at a low-skill level, twice as many as among the children of native-born. ${ }^{62}$ The remainder takes up a highly-skilled job.

154. The most prominent way for youth in Austria to find their first job is through family and friends, especially for the native-born children of immigrants. About $35 \%$ of the 15 to 34 year olds who managed to find a first job used this channel compared with $27 \%$ of the children of natives. Another major pathway is through previous work experience with the first employer, i.e. through internships or apprenticeships. While one quarter of the children of natives found their first job this way, this was only the case for $15 \%$ of the children of immigrants. The differences are not associated with differences in the educational level and the number of completed internships. ${ }^{63}$

\section{The impact of the crisis on the school-to-work transition}

155. In the aftermath of the economic crisis, youth unemployment in Austria experienced a steep rise in 2009 (see Figure 10). Particularly affected were the children of immigrants, especially young women. The latter experienced a sharp increase in unemployment that peaked at about $40 \%$ in 2009, compared with about $10 \%$ for the children of native-born. ${ }^{64}$

Figure 10. Unemployment rates by migration background and gender, aged 15-24 and not in education, 2008-2010
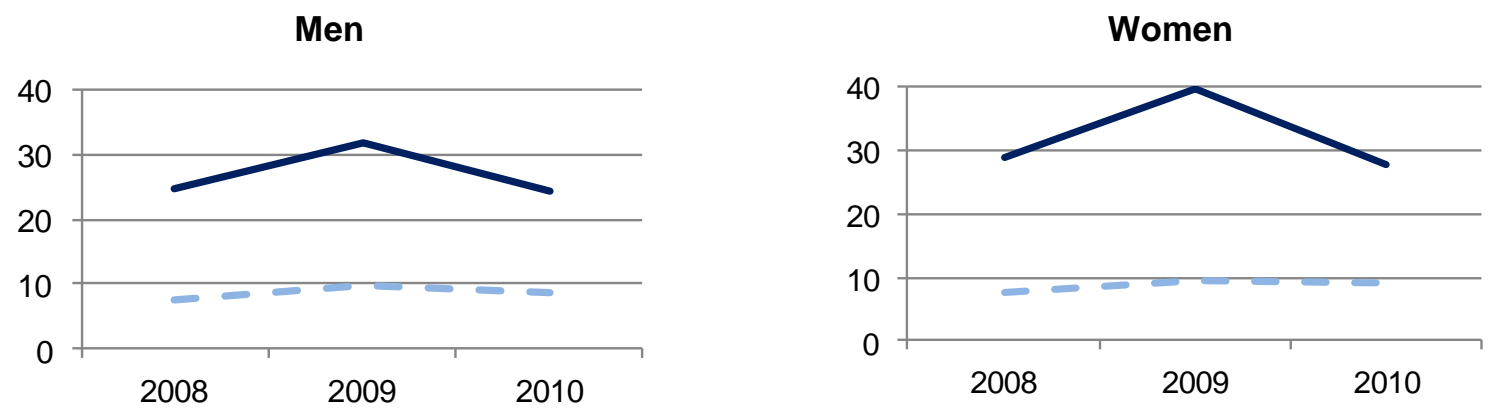

- Children of natives Native-born children of immigrants

Source: Austrian Microcensus (data provided by Statistics Austria).

156. Partly in response to the crisis, but also as an element of a long-term effort to decrease youth unemployment that has shaped active labour market policy over the past decade, the Federal Ministry for

62 These findings also broadly hold with respect to the current job.

63 Children of immigrants and children of native-born have the same share of youth who succeeded in finding their first job through an unsolicited application (17\%). Placement through the Public Employment Service (AMS) appears to be a neglected pathway, as it was only used by $5 \%$ of youth overall. However, this is partly explained by the fact that youth without prior insurance periods will not receive unemployment benefits, which often constitutes the reason for first contact with the AMS.

64 Note that the youth aged 15-19 who are not in education tends to be a negatively selected group, since the vast majority - including children of immigrants - pursues upper- and post-secondary education. In Austria, the share of children of immigrants in the age-group 15-19 is more than twice as large as among the 20-24 year old, due to the large inflows following the fall of the Iron curtain and the wars in the former Yugoslavia. Part of the high youth unemployment for children of immigrants in the age-range 15-24 is thus attributable to their biased age composition. A stark increase in 2009 is also observed after accounting for this. 
Labour and Social Affairs established a Youth Employment Pact in $2008 .{ }^{65}$ At the core of this measure is a training guarantee (Ausbildungsgarantie) that ensures all unemployed youth a placement offer in a job or training measure until the sixth month of unemployment, thereby aiming at the prevention of long-term unemployment. In 2009, EUR 120 million were provided for this measure which placed 138000 young people in employment and 83000 in training courses. The programme is still ongoing.

\section{Labour market outcomes of the children of immigrants}

157. As outlined in Section I, the overall employment outcomes for youth in Austria are rather favourable in international comparison, which is often attributed to the strong dual vocational system that also yields comparable results in the Netherlands, Germany and Denmark (see e.g. Dornmayr, 2010; and Hofer and Lietz, 2004). A closer look at the employment rates for the children of immigrants by gender, age-cohort and parental origin is given in Table 11. Two interesting patterns can be observed. First, female offspring of immigrants have larger gaps vis-à-vis the offspring of natives than their male counterparts. Second, across all groups of offspring of immigrants one observes significantly larger gaps among the younger cohort - in particular for the children with parents from Turkey. Due to a lack of longitudinal data, it is unfortunately not possible to discern whether this is due to the fact that the offspring of immigrants have generally more difficulties in the early years after school-leaving and then catch up or whether this is a cohort effect (i.e. young children of immigrants have more difficulties than older cohorts used to have). ${ }^{66}$

Table 11. Employment/population ratios and unemployment rates by immigrant status and gender, aged 15-24 and 25-34, not in education, 2009/2010

\begin{tabular}{|l|cc|cc|}
\hline & \multicolumn{2}{|c|}{ Men } & \multicolumn{2}{c|}{ Women } \\
& $15-24$ years & $25-34$ years & $15-24$ years & $25-34$ years \\
\hline Children of native-born & 84 & 92 & 83 & 86 \\
Native-born children of immigrants & -18 & -9 & -31 & -18 \\
...parents from & & & & \\
$\quad$ Ex-Yugoslavia & -16 & -10 & -21 & -15 \\
$\quad$ Turkey & -22 & -6 & -43 & -31 \\
\hline \hline All & 81 & 90 & 77 & 79 \\
\hline
\end{tabular}

Note: The figures for the children of immigrants refer to the employment rates of children of native-born minus the employment rates of native-born children of immigrants.

Source: Austrian Microcensus (data provided by Statistics Austria).

158. As seen above, children of immigrants are overrepresented in the lower educational tracks. This explains part of the difference in labour market outcomes, since these vary substantially by type and level of previous schooling (see Figure 11). Apprenticeship seems to be a beneficial school-to-work-transition pathway for both the children of natives and the children of immigrants, but the latter seem to benefit disproportionally from it. If they followed this pathway, they achieve employment rates of roughly $85 \%$, about the same as the native-born. The positive association between apprenticeship and the outcomes of immigrant offspring has already been found in other OECD countries. Notably in the Netherlands and Germany, children of immigrants have a disproportionally higher chance to be in employment if they follow this track compared with other choices (see OECD, 2007; OECD, 2008a). As in these countries,

65 For a review of active labour market policy for youth in Austria between 1994 and 2010, see BMASK (2010a).

66 In principle, one could shed some light on this important issue by looking at the outcomes of children of immigrants five or ten years ago. However, information on the native-born offspring of immigrants is only included in the Austrian Microcensus since 2008. 
children of immigrants in Austria are underrepresented in this track, as they only account for $8 \%$ of apprentices compared with $11 \%$ in total upper secondary education.

Figure 11. Employment rate by highest educational attainment, children of natives vs. native-born children of immigrants, aged 15-34 and not in education, 2009/2010

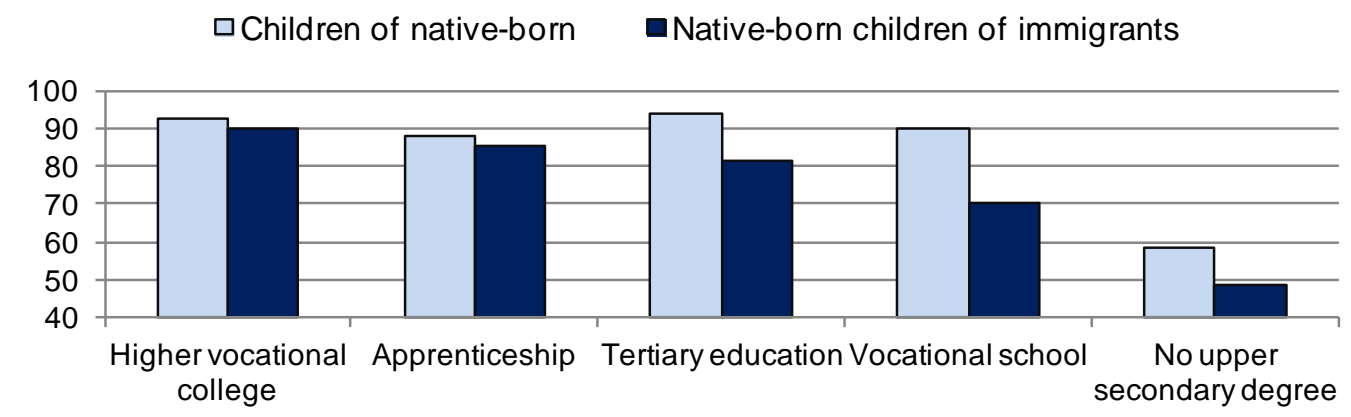

Note: Persons whose highest qualification is from an upper secondary academic school are not included as this applies only to a small group. Moreover, this is not a vocational qualification, but is usually supposed to be followed by a tertiary degree. Employment rates are $89 \%$ for the children of native-born and $77 \%$ for the native-born children of immigrants.

Source: Austrian Microcensus (data provided by Statistics Austria).

159. There is one qualification that is associated with even higher employment outcomes than apprenticeships - a higher vocational college degree. After completion of a five-year course of joint vocational and general education, native-born immigrant offspring achieve employment rates of roughly $90 \%$. Indeed, higher vocational colleges appear to be able to offset disadvantages stemming from socioeconomic background better than either purely vocational or general schools (Bacher, 2003). It is not clear whether the positive outcomes of higher vocational college attendants might be a selection effect of the grouping of particularly well-performing students with a migration background into this track, or whether other factors play a role. This issue merits further scrutiny, to assess if an even higher representation of children of immigrants in this track would promote their labour market integration.

160. Immigrant offspring with tertiary qualifications have significantly lower employment rates than those with the before-mentioned vocational qualifications. Moreover, there is a large gap between their outcomes and the employment rate of the children of native-born, which remains even after controlling for socio-economic characteristics (see Table 12). It thus appears that children of immigrants in Austria benefit more from higher vocational training and apprenticeships than from tertiary education. This is in line with findings from Section III, i.e. gaps in employment rates are particularly pronounced for the highly-skilled in Austria. In contrast to findings for immigrants themselves, the unfavourable labour market outcomes for the native-born children of immigrants can, however, be attributed neither to problems connected with the recognition of their qualifications, nor to restrictions in labour market access, thereby pointing to other structural obstacles, which will be discussed in more detail in the next section.

161. Differences in outcomes are largest, however, for youth who completed vocational schools that offer school-based intermediate-level programmes without extensive on-the-job training. After having completed this track, the children of immigrants have an employment probability that is 18 percentage points lower than that of the children of natives (see Table 13). 
Table 12. Percentage-point difference in labour market outcomes by type of highest qualification, native-born children of immigrants vs. children of native-born, aged 15-34, 2009/2010

\begin{tabular}{|l|ccccc|}
\hline & $\begin{array}{c}\text { Higher } \\
\text { vocational } \\
\text { college }\end{array}$ & Apprenticeship & $\begin{array}{c}\text { Tertiary } \\
\text { Education }\end{array}$ & $\begin{array}{c}\text { Vocational } \\
\text { school }\end{array}$ & $\begin{array}{c}\text { No upper } \\
\text { secondary } \\
\text { degree }\end{array}$ \\
\hline Probability to be in employment & -3 & -1 & $-12^{\star *}$ & $-18^{\star \star *}$ & $-5^{\star \star}$ \\
\hline \hline $\begin{array}{l}\text { Reference group: children of native-born } \\
\text { Controls: Age, Vienna, children, marital status, gender, year }\end{array}$ & & & & \\
\hline
\end{tabular}

Note: Marginal effects after probit estimation. ${ }^{* * *},{ }^{* *},{ }^{*}$ denotes significant at the $1 \%, 5 \%$ and $10 \%$ level, respectively. Shaded areas mark figures that are statistically not significant.

Source: Austrian Microcensus (data provided by Statistics Austria).

162. Particular policy attention needs to be devoted to youth who do not pursue upper secondary education and who are not in employment either (the so-called low-educated NEET). This "population at risk" is small among the native-born (3\%), but accounts for $11 \%$ of native-born immigrant offspring (see Table 13) and almost one fifth of the children with parents from Turkey. Once again, the offspring of parents from the former Yugoslavia fare better than the children of immigrants in general.

Table 13. Percentage of "early school leavers" and the "population at risk" (low-educated NEET) in the overall population, by migration background, aged 15-24, 2009

\begin{tabular}{|l|c|c|}
\hline \multirow{2}{*}{ Migration background } & "Early school leavers" & "At risk" \\
\cline { 2 - 3 } & \multicolumn{2}{|c|}{ in \% } \\
\hline Children of native-born & 5 & 3 \\
Native-born children of immigrants & 18 & 11 \\
...parents from: & & 9 \\
$\quad$ successor country of Ex-Yugoslavia & 16 & 18 \\
Turkey & 29 & \\
\hline
\end{tabular}

Note: "Early school leavers" are persons without an upper secondary degree who are out of education. The "population at risk" is defined as early school leavers who are not in employment.

Source: Austrian Microcensus (data provided by Statistics Austria).

163. A group that seems particularly disfavoured in the Austrian labour market are young immigrants who arrived in Austria between the age of 15 and 19. They make up some 3\% of the population aged 20-34 and the majority holds no Austrian degree. Instead, they hold predominantly low- (48\%) and medium$(45 \%)$ level qualifications from their origin countries. With an employment rate of only $63 \%$, they are about 20 percentage points less likely to be employed than the native-born children of immigrants who completed their education in Austria. This is a group which is neglected in the current policy framework, since they generally do not receive a structured integration offer.

164. The most important employer for the native-born in Austria is the public sector, accounting for more than $14 \%$ of employment in general and $8 \%$ for the offspring of natives in the age-group 20-29. Children of immigrants are significantly underrepresented - the public sector accounts for only $4 \%$ of their employment. While the offspring of immigrants from the former Yugoslavia are relatively well represented with almost $7 \%$ among those in employment working in the public sector, the incidence of employment in the public sector among the offspring with a Turkish background is particularly low (2\%). These differences do not seem to stem from the fact that part of the public sector is restricted to nationals, since almost $80 \%$ of the children of Turkish immigrants have Austrian nationality compared with $60 \%$ of the offspring of immigrants from the former Yugoslavia. 
165. By employing immigrants, the public sector can act as a role model for the private sector. Employment in the public sector can also increase the visibility of immigrants in daily life and can contribute to enhancing the understanding of immigrants' needs by public institutions. When immigrants are employed in certain key occupations such as teaching, they can also serve as a role model for others, notably immigrant youngsters. Because of this potentially beneficial contribution of the public sector, other OECD countries have recently made strong efforts to increase the employment of children of immigrants in this sector, and these have met with some success, notably in Norway, Belgium and the Netherlands (see OECD, 2008a; and Liebig, 2009). In Austria, however, apart from a few initiatives at the sub-federal level, there are no measures in place to enhance the presence of immigrants in public sector employment. This issue has also been largely neglected in the 2009 National Integration Plan.

\section{Inter-generational mobility}

166. Across all indicators, the performance gaps of immigrant offspring in the education system and the labour market are large, but these need be put into perspective since their parents are largely overrepresented among the low-educated. Indeed, in a survey among 1000 children of immigrants, ${ }^{67}$ two thirds of those with a low-educated father were found to have improved their educational outcomes. Similar tendencies were observed for occupational status (see Weiss, 2007). Nevertheless, intergenerational mobility seems to be lower than among children of natives. Among those in employment who have a father in a blue-collar job, the children of immigrants were twice as likely to be in a blue-collar job themselves.

167. Likewise, in an analysis based on the 2009 ad-hoc module of the Austrian Microcensus on the school-to-work transition of youth indicated that differences in intergenerational mobility between offspring of immigrants and children of natives are especially pronounced for youth with low-educated parents (Knittler, 2011). Among the 15 to 34 year olds whose parents did not obtain an upper secondary degree, $53 \%$ of the children of immigrants did not achieve a higher education level, compared with only $14 \%$ of the children of natives. For the offspring of better educated parents, no differences in intergenerational mobility could be found. ${ }^{68}$

168. Inter-generational mobility can also be observed indirectly through a comparison of gaps in education outcomes and employment rates between the population with and without a migration background for different cohorts. ${ }^{69}$ With respect to young men, Table 14 shows that the overall difference in the probability to be low-educated is larger for immigrant offspring than for the generation of their immigrant parents. ${ }^{70}$ With respect to women, the gap is about the same for both cohorts at the aggregate level and has even narrowed considerably for the children of immigrants from the former Yugoslavia.

67 The sample consisted of 1000 youth aged 16 to 26 years who were predominantly of Turkish or Yugoslav origin and had either been born in Austria or immigrated before the age of four.

68 Due to limits in the sample size of the 2009 ad-hoc module, Knittler (2011) employed a broad definition of "children of immigrants" including both native-born children of immigrants and young immigrants. The sample was also too small to conduct analysis separately by country of origin.

69 This approach allows for larger samples, since it does not require the variable on the parents' level of education, which is only included in the ad-hoc module (i.e. only in the second quarter of 2009). Hence, the full annual Microcensus can be used and although the actual parent-child relationship cannot be traced back here, this approach has the advantage of permitting separate analysis for different groups of immigrants and their offspring.

70 Note that the education outcomes of the children of immigrants are nevertheless better than those of their parent generation. However, the education outcomes of young men without a migration background have improved more strongly vis-à-vis their parents. 
Table 14. Percentage-point differences in the probability to be low-educated, population with a migration background vs. population without migration background, aged 20-29 and 45-54, for those not in education, 2009/2010

\begin{tabular}{|c|c|c|c|c|}
\hline & \multicolumn{2}{|c|}{ Men } & \multicolumn{2}{|c|}{ Women } \\
\hline & aged $45-54$ & aged $20-29$ & aged $45-54$ & aged $20-29$ \\
\hline $\begin{array}{l}\text { Share of low-educated } \\
\text { in the population without migration background (in \%) }\end{array}$ & 9 & 8 & 20 & 8 \\
\hline $\begin{array}{l}\text { Percentage-point differences } \\
\text { population with migration background vs. population } \\
\text { without migration background (in \%-points) }\end{array}$ & $\begin{array}{c}\text { Foreign-born vs. } \\
\text { native-born }\end{array}$ & $\begin{array}{l}\text { Native-born children } \\
\text { of immigrants vs. } \\
\text { children of natives }\end{array}$ & $\begin{array}{c}\text { Foreign-born vs. } \\
\text { native-born }\end{array}$ & $\begin{array}{l}\text { Native-born children of } \\
\text { immigrants vs. } \\
\text { children of natives }\end{array}$ \\
\hline All foreign-born / children of immigrants & 16 & 19 & 21 & 21 \\
\hline from Ex-Yugoslavia & 14 & 17 & 38 & 21 \\
\hline from Turkey & 69 & 31 & 68 & 31 \\
\hline
\end{tabular}

Note: Low-educated is defined as not having acquired an upper secondary qualification and is equivalent to ISCED level 0-2. For the cohort of 45 to 54 year olds, migration background is defined as being foreign-born. For the cohort of 20 to 29 year olds, migration background is defined as being native-born with two foreign-born parents. The figures for foreign-born/children of immigrants refer to the differences compared with the native-born/children of natives. Positive values mean that the foreign-born/children of immigrants are more likely to be low-educated than the native-born/children of natives

Source: Austrian Microcensus (Data provided by Statistics Austria).

169. Noteworthy, however, is the improvement of education outcomes for youth with a Turkish background compared with their immigrant parents. Both for young men and women, the gaps in the probability to be low-educated have narrowed by more than half. Although they are still 30 percentage points more likely to be low-educated than the children of natives, this indicates a rather high intergenerational mobility of immigrant offspring with a Turkish background in the Austrian education system.

170. Regarding employment for men, Table 15 shows the gap in the probability to be employed is only half as large for immigrant offspring as it is for the cohort of the immigrant fathers. For offspring with Turkish origins, the gap has decreased sharply by three quarters, but they still face more than twice the gap that is observed for children with parents from the former Yugoslavia.

Table 15. Percentage-point differences in the probability to be in employment, population with a migration background vs. population without migration background, aged 20-29 and 45-54, for those not in education, 2009/2010

\begin{tabular}{|c|c|c|c|c|}
\hline & \multicolumn{2}{|c|}{ Men } & \multicolumn{2}{|c|}{ Women } \\
\hline & aged $45-54$ & aged 20-29 & aged $45-54$ & aged $20-29$ \\
\hline $\begin{array}{l}\text { Employment/population ratio } \\
\text { in the population without migration background (in \%) }\end{array}$ & 89 & 90 & 81 & 87 \\
\hline $\begin{array}{l}\text { Percentage-point differences } \\
\text { population with migration background vs. population } \\
\text { without migration background (in \%-points) }\end{array}$ & $\begin{array}{l}\text { Foreign-born vs. } \\
\text { native-born }\end{array}$ & $\begin{array}{l}\text { Native-born children of } \\
\text { immigrants vs. } \\
\text { children of natives }\end{array}$ & $\begin{array}{l}\text { Foreign-born vs. } \\
\text { native-born }\end{array}$ & $\begin{array}{l}\text { Native-born children of } \\
\text { immigrants vs. } \\
\text { children of natives }\end{array}$ \\
\hline All foreign-born / children of immigrants & -10 & -5 & -14 & -21 \\
\hline from Ex-Yugoslavia & -10 & -2 & -13 & -15 \\
\hline from Turkey & -20 & -6 & -37 & -31 \\
\hline
\end{tabular}

Note: For the cohort of 45 to 54 year olds, migration background was defined as being foreign-born. For the cohort of 20 to 29 year olds, migration background was defined as being native-born with two foreign-born parents. The figures for foreign-born/children of immigrants refer to the differences compared with the native-born/children of natives. Negative values mean that the foreign-born / children of immigrants are less likely to be in employment than the native-born/children of natives.

Source: Austrian Microcensus (data provided by Statistics Austria).

171. For young women, the picture is different at first sight. Overall, gaps have increased for immigrant offspring compared with the cohort of their mothers. Looking separately at the two main groups with a migration background, one observes a small improvement for the offspring of Turkish immigrants and virtually no difference for those with a background from the former Yugoslavia. In relative terms, 
inter-generational improvements in employment outcomes thus appear to be largest for the offspring of Turkish origin.

\section{Policy measures to facilitate the labour market integration of immigrant offspring}

172. It appears that career-guidance programmes and job-application training are not yet well integrated into upper secondary education in Austria (see AMS Jugendliche Wien, 2011; OECD, 2010b). Participation in such measures depends largely on the motivation of individual teachers. Counselling facilities (Berufsinformationszentren, BIZ) are, however, available at the AMS, as well as in 60 regional career information centres run by the Economic Chamber. Both the AMS and the social partners are, moreover, strongly in favour of a reinforced co-operation with schools in this matter (see AMS, 2011). In Vienna, the AMS maintains a special agency for youth. About $60 \%$ of its clients are children of immigrants. There are also a number of additional measures offered for immigrant offspring in Vienna (see Box 6).

\section{Box 6. Measures to facilitate the school-to-work transition of immigrants' offspring in Vienna}

Given the disadvantages of immigrants' offspring in the labour market, their school-to-work-transition is a major concern for Austrian integration policy makers and their partners. Quite a number of projects have already been established by different actors that aim at facilitating the school-to-work-transition for youth at risk. While most projects do not target immigrants exclusively, the Integrationshaus in Vienna offers measures that address the children of immigrants specifically.

The Integrationshaus is a centre for the accommodation and integration of asylum seekers and immigrants, providing general advice, professional counselling, and language and training courses to facilitate labour market integration. It hosts the Dynamo network that co-ordinates a range of different projects all aiming at facilitating the labour market integration of immigrants' offspring. The projects have a modular structure which allows young people aged 15 to 25 to follow a course that is tailored to their individual needs and educational goals. One branch of projects provides youth with the basic qualifications and language training needed to proceed to a secondary education diploma. A second branch assists with finding employment or an apprenticeship, for example through participation in a mentoring project. The network is supported by actors such as the AMS, the Chamber or Labour, the Vienna Employment Promotion Fund (WAFF) and the Ministry of Education, and co-financed by the European Social Fund (ESF). Each day, between 180 and 200 young people participate in education measures co-ordinated by Dynamo.

While Dynamo targets young people who have already finished school, there are some other projects that aim at preparing youth for successful labour market integration while they are still in regular education. The project C'mon 14, implemented in 2010, aims at providing youth aged 14 to 17 with information, counselling and case management to prevent early school dropout and to facilitate their school-to-work-transition. The project's target group consists of disadvantaged pupils and school drop-outs among which children of immigrants are strongly overrepresented. The project is still in its pilot phase and limited to the city of Vienna. Its budget of roughly EUR 2 million is partly funded by the ESF and co-financed by the Public Employment Service and other partners united under the Territorial Employment Pact, such as the Chamber of Labour and the Economic Chamber. The responsibility to co-ordinate funding and project partners resides with the WAFF. The project move.on offered by the Integrationshaus has a similar structure. In 2009, it provided professional and educational counselling for twelve classes of altogether 284 pupils who are in their last two years of lower secondary school.

173. Indeed, when compared with the labour market situation of offspring of natives, male children of immigrants appear to fare relatively well in Vienna. However, this does not hold for women (see Table A3.2 in the Annex).

174. Since 2008, the AMS has extended its funding of large-scale, workshop-based dual programmes that aim to compensate for the lack of apprenticeships in private companies through practical experience in 
workshops and in-school vocational training (Überbetriebliche Ausbildung). ${ }^{71}$ These programmes train students in vocational professions for up to three and a half years, but primarily aim at preparing them for a quick transition into regular apprenticeships. In 2009/2010, some 12300 places were created in such programmes, a 30\% increase over the year before. In 2010/2011, the number of places was once more increased to reach $13800(+12 \%)$. About EUR 15000 per capita were spent on this measure in 2008/2009, compared with 10000 for training in vocational schools and colleges, and roughly 6400 for regular apprentices (Dornmayr, 2010). Three quarters of the participants are in employment three months after participation in such schools, suggesting that they are relatively effective. Children of immigrants account for nearly half of the participants (see Table 7 above). ${ }^{72}$

175. In summary, the evidence shows that it is the female offspring of immigrants - especially those with parents from Turkey - who face the greatest difficulties in integrating into the Austrian education system and the labour market. There have been a number of initiatives to address this in the labour market, but most of these lack appropriate targeting. It also appears important to tackle the poor educational outcomes of immigrant offspring, in particular of women. Given the significant challenge of integrating the growing number of immigrant offspring who are about to enter or who have recently entered the labour market, and the significant gaps in education outcomes, a stronger, targeted and more co-ordinated policy effort is needed.

\section{Sources of persisting disadvantage across generations - and possible remedies}

176. The large and persistent differences in the employment outcomes, even of native-born children of immigrants with good qualifications, inevitably raise the question of other structural obstacles to immigrants' employment than their human capital.

\section{Networks and knowledge about labour market functioning}

177. One possible reason could be a lack of networks which creates in effect a structural barrier to employment. Although immigrants have networks as well, they are likely to be concentrated among persons from their own communities, which tends to limit their employment opportunities. It is difficult to understate the importance of networks for access to employment. In Germany, for example, almost 30\% of vacancies in 2008 were filled using personal contacts by employers; in enterprises with less than 50 employees, one out of two vacancies were filled using personal contacts (Klinger and Rebien, 2009). Using a larger definition of "personal contacts", evidence from Sweden indicates that as much as two thirds of all vacancy fillings involved some form of informal contacts (Behtoui, 2008).

178. There has been no quantitative study of this issue for Austria thus far. However, small- and medium-sized enterprises predominate in Austria - more than $60 \%$ of employment is in companies with less than 50 employees. As these companies tend to resort disproportionately to personal referrals, the importance of networks is likely to be high in Austria. Some rough indication is given by the Austrian Microcensus, which in 2010 included a question on how young people aged 15-34 found their first job.

71 In addition, the AMS has enlarged its subsidies for company-based apprenticeships since 2005 under the so-called "Blum Bonus" programme, which led to the creation of 10000 new subsidised apprenticeships until 2007 (Bildungsbericht, 2009).

72 As a measure to foster the re-integration of early school leavers into vocational tracks, the AMS, moreover, established so-called workshop schools (Produktionsschulen) that aim at enhancing practical skills through handson training programmes that are accompanied by social workers. At the end of 2010, 19 such schools existed in Austria and counted about 2000 participants (BMASK, 2010a). There has been no evaluation yet of their effectiveness. 
More than 30\% answered "through friends and relatives", and a further 23\% mentioned that they found their first job through previous employment (e.g. internships or vocational training) with the same employer.

179. The large importance of informal recruitment channels means that in practice many job vacancies, although not necessarily closed to immigrants and their children, may be filled in such a way that they have little opportunity for their candidacies to be considered. Immigrants and their children are therefore at a structural disadvantage compared with the native-born, although it is currently not possible to quantify the importance of this disadvantage for Austria.

180. Another, related structural disadvantage from which migrants and their offspring tend to suffer is a lack of information about labour market functioning. This involves knowledge about how to draft CVs and letters of introduction, to identify appropriate job opportunities, and how to respond and react in recruitment interviews. This seems to be a particular issue in the Austrian labour market, which has a number of particularities such as the use of academic titles in day-to-day contacts. This can be a problem for immigrants who came from countries where practices and norms, both procedural and cultural, may be different. Since this information is at least in part transmitted via parents or close friends, the offspring of immigrants continue to be at a structural disadvantage.

181. Mentorship programmes are one way of overcoming the obstacles arising from a lack of employment-relevant networks and lack of information about labour market functioning. These programmes have become increasingly popular in some OECD countries. Denmark and France, in particular, have introduced them on a rather large scale in recent years. In mentorship programmes, an immigrant is matched with a native-born person of similar sex, age and occupation, to the extent possible. The native-born person provides the immigrant with basic information on procedures, institutions, howthings-are-done-here, etc. The mentor can also make the immigrant benefit from his/her own network of contacts and, in some cases, even act as an intermediary to potential employers. These programmes are attractive to host countries since they involve the native population. In addition, the cost to the host country is limited, because the mentors are generally volunteers, although they do undergo special training to sensitise them to cultural differences and to immigrant expectations.

182. In Austria, the scale and scope of mentorship and other networking-type measures have been rather limited to date. There have been a few local initiatives, but these tend to be of very small scale, generally involving few migrants. One larger programme is that of the Austrian Economic Chamber, in cooperation with the AMS and the Austrian Integration Fund (ÖIF), which recently initiated a mentorship programme, matching employers or senior staff of enterprises with immigrants who seek employment in their mentor's sector or occupation. Up to now, the scale of the programme has been limited; only about 450 immigrants have taken part in it.

\section{Discrimination}

183. Another structural obstacle which immigrants and their children face is discrimination on the basis of ethnic origin, and in particular discrimination in hiring by employers. This issue has received little attention in Austria thus far, and efforts to enhance legislation and policies against ethnic discrimination are recent. Anti-discrimination legislation used to be limited to issues of gender equality and was only amended to cover origin-based discrimination in 2004, when Austria was obliged to implement the EU Racial Equality Directive. ${ }^{73}$ Anti-discrimination law, as set by the Equal Treatment Act, has since

73 Austria chose to implement the directive by adding the aspects of ethnic origin, religion and belief as new fields of application to the already existing law for gender equality. 
prohibited discrimination based on race, ethnic origin, religion or belief, age and sexual orientation in employment. Since then, discrimination has been furthermore prohibited with respect to education, social security (including social insurance, healthcare and social benefits) and the supply of public goods and services (including housing). Apart from this, there has not been any major policy initiative against ethnic discrimination thus far.

184. Since 2004, Austria has been maintaining two main public institutions at the federal level to implement the Equal Treatment Act. The first is the Equal Treatment Commission, situated at the Federal Chancellery's section for Women and Equality. It examines cases put forward by presumed victims and assesses their coverage by the Equal Treatment Act. This service is free of charge and aims at settling disputes before the initiation of actual court proceedings. The outcome of the process is legal recommendations which are, however, not binding (unlike in other countries such as Australia, Canada and Norway where non-complying employers can be fined, see OECD, 2008a) and tend to remain vague. The assessment procedure itself is rather lengthy and takes on average between nine months and one and a half years. Potential victims thus face long waiting times with little expectation of an outcome that is ultimately to their benefit. Accordingly, few persons seize this opportunity. In 2006/2007, the commission received only 29 requests related to incidents of ethnic discrimination in employment. Employees of the federal public sector who feel discriminated against at work need to address a special commission, the Federal Equal Treatment Commission.

185. The second key body of Austrian anti-discrimination policy is the Ombud for Equal Treatment, which complements the activities of the Equal Treatment Commission. The ombudspersons offer counseling as well as representation of potential victims of discrimination against the employer and can attend meetings of the Equal Treatment Commission in an advisory function. Furthermore, the ombudspersons engage in spreading information about the rights of victims through information material, the internet, as well as by giving workshops, lectures and as speakers in public debates and conferences. There are several ombuds, one for equal treatment in employment irrespective of gender, one for discrimination in employment based on other characteristics including ethnicity and finally one for all sorts of discrimination in areas outside of employment. In 2008/2009, the Ombud received 308 requests for counselling in cases of ethnic discrimination in employment, one third of all cases treated by the responsible ombud. Almost two-thirds of these requests were filed by residents of Vienna. This strong underrepresentation of immigrants from outside the capital seems to be attributable to the fact that this ombud has an agency only in the capital. Immigrants living outside of Vienna thus have to displace themselves to seek advice in a personal meeting. The ombudsman for gender discrimination in employment, in contrast, maintains several regional offices and received almost 6600 requests in 2008/2009. ${ }^{74}$

186. In addition to the federal structure, different regional anti-discrimination acts exist and are enforced at state level. Federal states maintain own counselling bodies to reinforce equal treatment in their fields of responsibility (that is, employment in the public sector at state or municipal level, as well as with respect to public services and goods provided by the state or a municipality). However, these facilities have a rather limited scope, as they generally do not cover discrimination by private actors.

187. A complementary structure is offered by the social partners, most notably by the Chamber of Labour. In matters related to the employer-employee relationship, including cases of perceived discrimination, the chamber provides legal counselling to its members (see Box 4). However, since membership is conditional upon entry into the labour market, family or humanitarian migrants who have not yet been in employment in Austria have generally no access to this facility. This is unfortunate, given

74 For a detailed account on the ombuds offices' activities in $2008 / 2009$, see Gleichbehandlungsanwaltschaft Österreich (2010). 
that this group would seem to be particularly vulnerable to discriminatory hiring practices that might hamper their labour market integration.

188. On the side of non-governmental actors, immigrants in Austria benefit from the steadily growing anti-discrimination network that is provided through the Litigation Association Against Discrimination (Klagsverband, see Section II). Funded partly by the Federal Ministry of Labour, Social Affairs and Consumer Protection, the Federal Chancellery's section for Women and Equality and the state of Salzburg, it offers legal assistance and general information on anti-discrimination legislation and provides training courses and seminars on this topic. ${ }^{75}$ The Klagsverband is the only NGO in Austria that is legally entitled to stand in court and to intervene as a third party in cases of discrimination. Non-member NGOs have no procedural rights and hence cannot perform advisory functions in court (see Schindlauer, 2007).

189. Although the existing sources of legal support for potential victims of ethnic discrimination in Austria are rather extensive, legal intervention in such cases remains rare. Individual law suits against employers demand a considerable amount of courage on the part of the potential victims, as they risk stigmatisation in their enterprise and on the local labour market (see Manolakos and Sohler, 2005). ${ }^{76}$ Moreover, the Austrian legal framework does not allot substantial remedies for victims, thereby lowering incentives to pursue legal actions for redress. Instead, reinstatement is ordered if a lay-off has been found to be discriminatory, but as many victims are reluctant to return to their old employer, the actual sanction is rarely enforced (Schindlauer, 2007).

190. Another factor lowering the number of actual anti-discrimination proceedings might be a general lack of public awareness concerning the unlawfulness of discriminatory hiring practices against immigrants and their offspring. Less than $30 \%$ of the Austrian population know that such practices are prohibited by law (see Figure 12). This share is among the lowest in European OECD countries.

Figure 12. Public awareness about legal anti-discrimination provisions, selected OECD countries, 2007

$\square$ Awareness of law prohibiting discrimination based on ethnic origin when hiring new employees

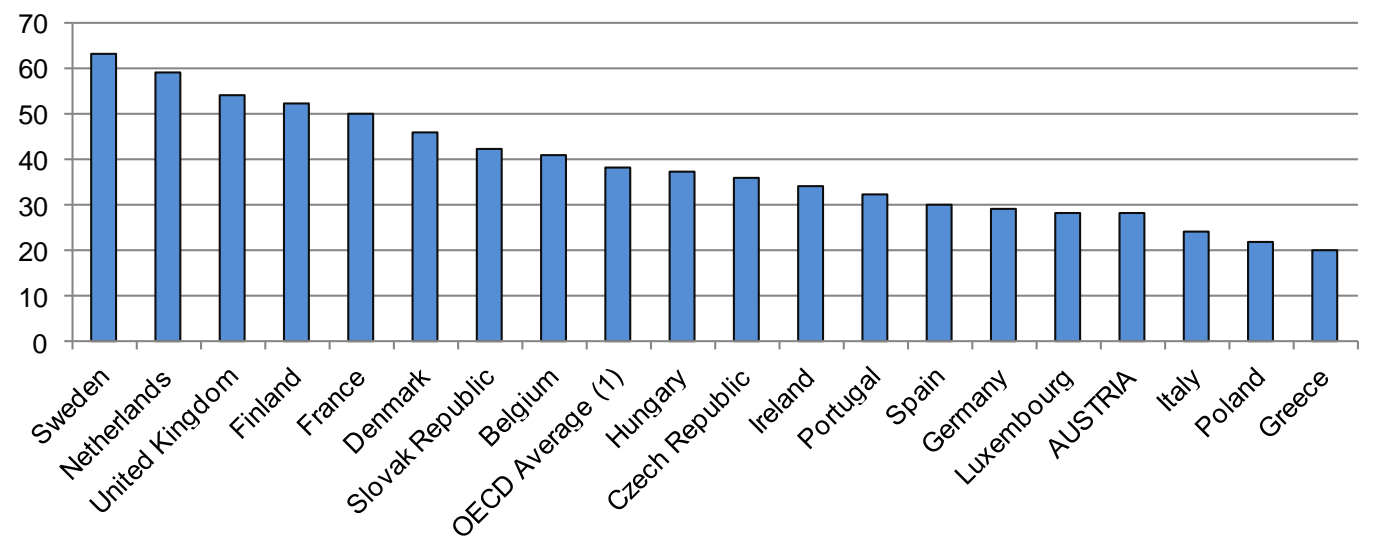

Note: The bars correspond to the percentage share of persons answering "Yes" to the question "Please tell me whether, in your opinion, in your country there is a law which prohibits the following types of discrimination when hiring new employees - discrimination on the basis of ethnic origin". 1: The OECD average refers to the average of all countries included in the figure.

Source: Adapted from OECD (2008a), figure 3.7; original source: European Commission (2007).

75 For a detailed account on the Klagsverband's activities in 2009, see Klagsverband (2010).

76 Class actions as used, for example, in the United States could provide a remedy to this problem, but the Austrian legal framework does not yet provide this opportunity for cases of discrimination (for more information on class action in the United States, see Sherwyn, 2009). 
191. The lack of awareness about anti-discrimination provisions in Austria runs parallel with a lack of research on the topic. It is difficult to prove, for instance, selective hiring practices that disfavour persons with particular characteristics, such as an immigrant background. The very factor that stirs the employer's refusal of certain candidates cannot be identified easily, since it is always possible that other unobserved characteristics account for hiring preferences rather than outright discrimination.

192. An increasingly widespread way to single out discriminative behaviour in employers' hiring practices is to conduct large-scale paired audit studies. These have been carried out in a large and growing number of OECD countries in recent years. Such experimental studies employ the method of matched pairs, originally developed by the ILO. Applications to the same job are submitted by two (fictitious) candidates who differ essentially in only one attribute indicating their ethnic origin. ${ }^{77}$ Testing studies following this methodology have been conducted in seven out of the ten countries under review thus far (Belgium, Denmark, France, Germany, the Netherlands, Sweden and Switzerland), with an additional Norwegian study underway. The findings pointed towards the prevalence of discrimination at significant levels in all of the seven countries. To get invited to a job interview, it is not uncommon for persons with foreign-sounding names to have to write up to four times as many applications as persons without a migration background who have an otherwise equivalent CV (see OECD, 2008a).

193. In Austria, no such testing study has been conducted yet. To date, there has only been a smallscale audit experiment on discrimination against job applicants of African origin (Satner and AdamMaxova, 2002). The study found that applicants with African-sounding names had to write twice as many applications to be invited for a job interview compared with otherwise similar candidates who had an Austrian-sounding name. The limited scale of this study - only $72 \mathrm{CVs}$ were sent to employers - does not allow for any generalisation of the finding, but underscores the need for further empirical research on this issue in Austria.

194. Apart from this, the only available evidence on immigrants' discrimination in Austria is based on subjective perceptions. Zucha (2003) examined feelings of being discriminated against of roughly 800 immigrants and their children with origins in the former Yugoslavia and Turkey who had participated in a survey by the Chamber of Labour. The findings suggested that experiences with discrimination were rather frequent in the building, cleaning, catering and hotel industry. Moreover, employees of small enterprises felt more often discriminated against than immigrants working in larger firms. This finding is in line with evidence from other OECD countries (see e.g. Carlsson and Rooth, 2006), pointing out that selective hiring to the disadvantage of immigrants tends to be more pronounced in smaller companies. Moreover, a survey among employers in the Netherlands revealed that small firms have a particularly limited awareness of anti-discrimination legislation and are thus less sensitive about its implications (Havinga, 2002). Given the predominance of small enterprises in the Austrian economy - more than $60 \%$ of employment is in companies with less than 50 employees - this seems to be a significant issue that merits further investigation.

195. In Austria, there are also a number of elements in the labour market framework that tend to be inherently discriminatory against immigrants. The first is the classification of foreign qualifications by the AMS. As mentioned earlier, foreign credentials which have not passed a formal recognition procedure are registered as "compulsory education not completed".

196. The Act on the Employment of Foreigners up to now has required employers to preferentially lay-off foreign workers who hold a first-time work permit valid for up to one year before firing Austrian nationals in a downturn. Although this provision had limited practical implications - only few migrants

77 In recent studies, this has usually been the name. Note that in Austria, such a testing would not be possible with respect to Slavic family names, as these are widespread even among offspring of natives. 
held such a permit - it signalled a preference against immigrants in the labour market. Under the revised Act on the Employment of Foreigners, which entered into force in July 2011, the provisions for preferential lay-off will be abolished, and labour market access for newly-arrived permanent-type migrants greatly facilitated.

197. A third element of institutional discrimination prevailed in the sphere of public housing over several decades until it was abolished in 2005 under the pressure of the EU "Directive on long-term residence status". Until then, almost all major cities, including Vienna, reserved community housing facilities to Austrian or other EU citizens. These facilities are particularly affordable and assure the decent lodging of families in need. Immigrants without Austrian or EU citizenship (depending on individual state regulation) were widely excluded from community housing. There is some evidence that this has contributed to the segregation of immigrants, in particular in sub-standard housing facilities (Kohlbacher and Reeger, 2007). Although only indirectly linked with labour market integration, housing has an important impact not only on labour mobility, but also on labour market and social integration in many other ways. When, as seems to be the case in Austria, limited access to housing is associated with geographical segregation in poor neighbourhoods, it can inhibit access to social networks (by which many vacancies are filled), hamper acquisition of the host-country language by immigrants and their children, and may also have important negative effects on the integration of the children of immigrants as childcare and education facilities often tend to be underdeveloped in these areas. ${ }^{78}$

198. The shortcomings of both research and policy on discrimination in Austria seem to express a lack of awareness with respect to issues of discrimination in the labour market. Only recently have there been some modest efforts to overcome discrimination in hiring and to incite employers to diversify their recruitment channels (see Box 7).

\section{Box 7. Policies to promote diversity}

Austria, like most other OECD countries, has put in place anti-discrimination legislation to address the problem of discrimination in hiring. However, as mentioned above, it is difficult to detect or to demonstrate discrimination, and indeed, the number of complaints related to hiring discrimination is small compared with the level of discriminatory behaviour that is revealed by testing studies in numerous OECD countries. The perceived lack of effectiveness of antidiscrimination legislation and the persistence of other structural obstacles to the employment of immigrants and their children have prompted governments to take more pro-active measures. A new policy line that has become prominent in many OECD countries in recent years is known as diversity policy. Belgium, in particular, has become a frontrunner in this, inspired by earlier Dutch policies of the 1990s. Diversity policies aim at achieving equal opportunities for disadvantaged groups in the labour market (including immigrants and their children) by incentives and measures with strong indirect targeting. Practices in Belgium (notably in Flanders) include, for example, the exclusive opening of certain job vacancies to disadvantaged groups in the labour market for a limited period, and financial and administrative support for companies who try to diversify their staff both in the hiring and promotion process. First results of an evaluation of this policy indicate that it appears to have contributed to the recent improvements in the labour market integration, in particular for the children of immigrants (see Van de Voorde 2010).

Efforts in other OECD countries have been less far-reaching, but are also on the rise (see OECD 2009a). In France, for example, companies have the possibility to pass an audit as to whether or not hiring and promotion practices are inherently discriminatory. If they pass the test and have demonstrably implemented additional actions to promote diversity, they can obtain a diversity label (label diversité) from the authorities in charge of integration. In order to receive the seal of approval, enterprises need to satisfy six criteria: a formal commitment by the enterprise to diversity; an active role of the social partners within the enterprise; equitable human resource procedures; communication by the enterprise on the question of diversity; concrete public measures in favour of diversity; and procedures to evaluate actual practices. France, like a growing number of other OECD countries including Belgium,

78 Note that this may be part of the explanation of the particularly low participation of children of immigrants in preschool education in Vienna. 


\section{Box 7. Policies to promote diversity (cont'd)}

the Netherlands and Germany, has also been promoting a "diversity charter" in which signatories commit themselves to favour diversity through recruitment and career management, as a strategy for greater efficiency and progress and to enhance their social relations. Without a precise follow-up of hirings and of career progress in signatory enterprises, it is difficult to have a precise idea of how effective this sort of measure is. There is undoubtedly a self-selection of already committed enterprises as signatories, although a formalisation of the process may have its usefulness in disseminating norms throughout the enterprise. Another measure that has been tested in a number of OECD countries, including France, Germany and Norway, are anonymous CVs.

In Belgium, Norway and the Netherlands, there has been a strong effort to enhance diversity in the public sector. The policies in place tackle the different points in the recruitment process where immigrants and their offspring are at a structural disadvantage. This has included the broad-based introduction of anonymous CVs, the targeted promotion of apprenticeship for young people with a migration background, internship opportunities to give them a first step into the labour market, and special training to help them pass the recruitment tests.

Among the broad array of measures available, only the diversity charter has been tried in Austria thus far, but only recently. The Economic Chamber launched in November 2010 a "Charta of Diversity in Austria" that aims at promoting diversity in Austrian companies. By April 2011, 18 companies had participated in the initiative, essentially large employers. Austria's National Action Plan for Integration, introduced in 2009, stipulates to combat discrimination as one of its major goals, but no concrete measures have yet been implemented to actually tackle the issue.

199. Given the lack of action at the federal level, some cities have implemented initiatives in their domain of competence, but these have remained limited in scale and scope. The most prominent example is the city of Vienna, which has developed an integration and diversity monitoring programme since 2007, in order to analyse the status of integration of the Viennese population in the most important areas of life (among others education and training, employment) and the management of diversity in the municipal administration. $^{79}$

200. It seems that public support for measures to provide equal opportunities in employment depending on ethnic origin is particularly low, with only a little more than half of the Austrian population being in favour compared with the OECD average of $70 \%$ (see Figure 13). About the same percentage acknowledges that there exist disadvantages in employment chances based on ethnic origin.

79 The results were published in the first Viennese Integration and Diversity Monitor in 2010 (see Magistratsabteilung 17, 2010). 
Figure 13. Percentage of the population believing that persons of a different ethnic background face disadvantages in chances of employment, training and promotion (1); and percentage of the population that supports measures to provide equal opportunities (2) for persons with a different "ethnic background", selected OECD countries, 2007

$\square$ Support for measures to provide equal opportunities in employment for persons with a different ethnic background

- Perceived disadvantages in chances of employment, training and promotion of persons with a different ethnic background

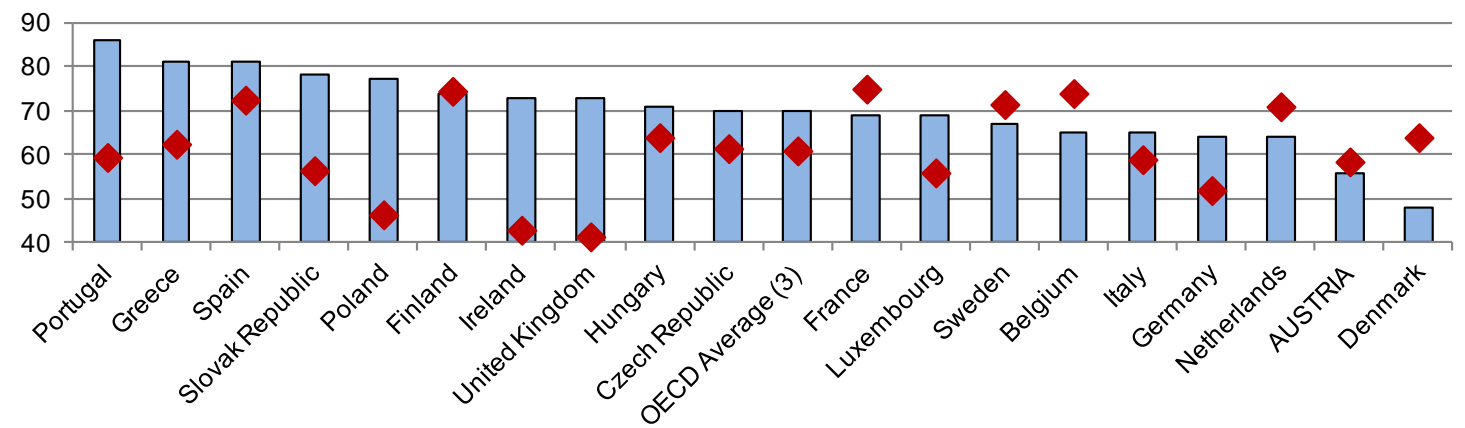

Note: 1: Share of persons answering "Less likely" to the question "Would you say that, with equivalent qualifications or diplomas, the following people would be less likely, as likely, or more likely than others to get a job, be accepted for training or be promoted persons of different ethnic origin or not white compared to the rest of the population". 3\% of respondents answered "More likely".

Note 2: Share of persons answering "In favour" to the question "Would you be in favour of, or opposed to, specific measures being adopted to provide equal opportunities for everyone in the field of employment?" Specific measures for people depending on "ethnic origin".

Note 3: The OECD average refers to the average of the countries included in the figure.

Source: Adapted from OECD (2008b), figure 3.8; original source: European Commission (2007).

201. In sum, the limited available evidence suggests a lack of knowledge about the prevalence of discrimination in Austria, and little use is made of the existing structures which, in addition, appear to cover only the legal aspects of combating discrimination. It thus seems important to put the issue into limelight and, in addition, to implement more pro-active measures - namely those which promote diversity - as has been done in other OECD countries. 


\section{Summary and recommendations}

Among the OECD countries, Austria has one of the largest shares of immigrants in the workforce, many of whom have arrived rather recently.

The overall labour market outcomes of immigrants are rather favourable in international comparison, which is due to good labour market conditions and a favourable mix of origin countries.

This tends to mask less positive labour market outcomes of some groups, in particular of immigrant women.
With $17 \%$ foreign-born, Austria is among the OECD countries which have large shares of immigrants in the workforce. There are three main groups of immigrants in Austria. The first are so-called "guestworker" migrants and their families, mainly from the former Yugoslavia and from Turkey, who came to Austria as a result of labour recruitment in the post-World War II economic boom and subsequent family migration. The second are humanitarian migrants, most of whom arrived after the fall of the Iron Curtain, an event which had a profound impact on migration to Austria. The bulk of humanitarian migrants are from the former Yugoslavia and from Eastern European countries. Finally, since Austria's accession to the EU in 1995 and the enlargement of the latter in 2004 and 2007, free-movement migration has accelerated and now accounts for the majority of new migration flows.

A first glance at the labour market outcomes for immigrants shows significant gaps between their outcomes those of and the native-born, albeit these are not larger than elsewhere. This holds especially when considering that $42 \%$ of immigrants live in Vienna (compared with $16 \%$ of the native-born), where labour market conditions are less favourable than in the remainder of the country. Even in Vienna, however, the labour market conditions are still better than in many OECD countries. Indeed, the rather flexible labour market and low unemployment seem to have contributed to the relatively high employment of immigrants and their children in international comparison, in particular for men. Austria has also a relatively favourable mix of origin countries, with the majority of immigrants coming from high-income countries (Germany being the main origin country) who tend to face less difficulties in the labour markets of all OECD countries. The bulk of the immigrants from lower-income countries are from the successor countries of the former Yugoslavia, with whom Austria has many historical and cultural ties and who have high employment rates for both genders.

The overall rather favourable outcomes mask persistent difficulties for some groups. The employment rate of immigrant women from lower-income countries is almost 20 percentage points lower than that of native-born women. Immigrant women from Turkey are particularly disadvantaged: their unemployment rate is five times higher than that of their native peers, and only $38 \%$ of those in workingage are in employment, an employment rate that is 30 percentage points below that of the native-born. Likewise, native-born offspring of immigrant parents aged 2029 are four times more likely than the offspring of natives to be both low-educated and neither in employment nor education or training. Again, the gaps vis-à-vis the offspring of natives are particularly large for those whose parents have come from Turkey, and for women. Overall, the poor outcomes of women with an immigrant background - both with respect to education and the labour market - call for urgent policy actions to improve them. 
The crisis negatively affected outcomes of immigrant men and immigrant offspring, but not of immigrant women.

\author{
The impact of \\ policies restricting \\ family migration on \\ the integration \\ outcomes should be \\ assessed.
}

There is a significant deficit in empirical research on integration, and it is important to overcome this as more and better data sources become available.

The current infrastructure for integration is highly dispersed.
The effect of the recent crisis had a strong impact on the unemployment rate of immigrant men, in particular those from Turkey, whose unemployment rate rose by almost ten percentage points in 2009 , before falling again. There was also a strong increase in the unemployment rates of immigrant offspring from the former Yugoslavia and from Turkey. In contrast, during the crisis, there was a countercyclical increase of almost ten percentage points in the employment rate of women from lower-income countries (other than ex-Yugoslavia and Turkey). This seems to be attributable, at least in part, to the so-called "added worker effect", that is, spouses entering the labour market to compensate for the actual or probable employment loss of the principal migrant.

In recent years, a number of measures have been taken to restrict family migration from lower-income countries. Their impact on integration outcomes needs to be assessed carefully. If they merely retard immigration, they may have a negative impact on integration outcomes. This seems particularly damaging in the presence of children. Analysis from the OECD's Programme for International Student Assessment (PISA) and other sources suggests that later arrival in Austria has a negative impact on the education outcomes of the children of the immigrants concerned.

The assessment of the labour market integration of immigrants in Austria is hampered by significant deficits in the data infrastructure. Apart from the census, the only dataset which allows for an identification of immigrants is the Microcensus. This only adequately captures the foreign-born population since 2004 and the native-born offspring of immigrants since 2008. As a result, empirical research on integration has been extremely limited to date. Better data are gradually becoming available as the Public Employment Services shift from an exclusive identification of current nationality in their files to the identification of previous nationality and the nationality of the parents (for those who are coinsured), thereby allowing for the identification of naturalised immigrants and their offspring. Likewise, a data warehouse is being developed which will link administrative data with the labour force survey. These new data sources should be exploited in quantitative research to enable informed, effective and targeted policy making.

Integration is a cross-cutting domain and thus, in all OECD countries, many stakeholders are involved in the process. However, the framework in Austria is among the most dispersed and complex of all the OECD countries which have been under review to date. For example, the assessment and recognition of foreign qualifications involves four different ministries, and there are a multitude of different procedures in place depending on the origin, domain and level of the degree. 
There are many small-scale projects at the local level which are difficult to assess.

The establishment of a central coordination body for integration at the chancellery would improve governance in this cross-cutting domain.

The social partners play an important role in labour market integration.

The framework governing the labour market access of immigrants is complex and lacks transparency.

In spite of some progress in recent years, there are still several administrative obstacles to the employment of some immigrant groups, and it is urgent to remove these.
Apart from the mainstream integration offers by the Austrian Public Employment Service, there are few federal measures in place at the federal level which aim at supporting immigrants' labour market integration. At the same time, there are a multitude of projects at the state and local level, and it is difficult to assess their impact. In any case, most of these projects are small-scale, time-limited and with multiple-level financing, making it questionable whether they are a cost-effective means of service provision for migrants.

The current complex and dispersed infrastructure for integration and the many small-scale projects call for a more co-ordinated policy approach, to ensure consistency and effectiveness of the integration framework, and to enable a better experience sharing about what works and what does not. Some modest efforts in this direction have recently been taken with the introduction of a National Action Plan for integration and the establishment of a State Secretariat for integration in the Federal Ministry of the Interior. Given the multitude of stakeholders involved and the variety of domains related to integration, a more cross-cutting coordination body should be seriously considered. The ideal location for this would be in the Federal Chancellery. It seems important to tackle this now as the children of immigrants are entering the labour market in increasingly large numbers.

A unique feature of the labour market setting in Austria is the strong involvement of the social partners. These are also among the main actors in labour market integration. The Chambers of Labour are among the main providers of advice, notably related to discrimination in the labour market and to training. The Economic Chamber recently initiated a mentorship programme for immigrants.

Austria is among the few OECD countries that do not provide full and automatic labour market access to all permanent-type migrants upon entry. Although most migrant groups now get immediate labour market access, there are many different permits with varying degrees of labour market access. On top of this, Austria has a unique system of numerical limits for new work permits that can be granted in a given year, depending on the share of the foreign population in the workforce. The restrictions may also have contributed to the particularly low employment rates of newly arrived immigrant women from lower-income countries, since these are among the few groups where the restrictions have been binding.

Over time, the labour market access of immigrants in Austria has gradually improved, and most permanent-type immigrants now either enjoy immediate labour market access or obtain this after a year. The new immigration law which entered into force in July 2011, brought about further facilitations. Since this date, only few groups still have limited labour market access, and these groups are small. However, for those immigrants concerned, there are some additional difficulties to overcome. For example, labour market participation is a precondition for access to most publicly funded language training labour market restrictions for migrants who can be expected to stay in the country for good hampers the integration process. In any case, since the groups involved are small, the remaining obstacles should thus be abolished, including the system of limits on the number of work permits for migrants who are already legally residing in Austria. 
A cautious opening of the labour market to asylum seekers at later stages of the process should be considered.
A more comprehensive integration programme for new arrivals, targeted at labour market integration, should be envisaged.

\section{Labour market integration measures have been stepped up recently.}

There has been
considerable effort
to integrate migrants
into shortage
occupations, and this
seems to have paid
off.

Language training is the largest integration-related
One group for which Austria is particularly restrictive are asylum seekers. This group is only issued work permits after three months, and only for seasonal occupations. Since the asylum process can be rather lengthy, the full labour market entry of those who eventually remain in Austria can be retarded significantly, with potentially adverse consequences on the long-term integration prospects. Clearly, a balance needs to be achieved between the facilitation of labour market entry for those who need protection and prevention of abuse of the asylum channel. Many OECD countries have opted for granting broader labour market access to asylum seekers at some stage of the process, once it has become clear that the request is not completely unfounded. Such a middle way should also be considered in Austria.

The unfavourable labour market outcomes of newly-arrived immigrant women from lower-income countries also raise the question of introduction offers for immigrants. Many OECD countries have recently introduced or extended structured integration programmes for new arrivals. These are lacking in Austria. The only structured "offer" for this group is an obligation to pass a language test, which is partially refunded for those who succeed. The implementation of an introduction programme for new arrivals, in particular for those who lack the basic skills to succeed in the Austrian labour market, should be seriously considered. Even if such programmes tend to be costly, the experience of the Scandinavian countries, which have implemented them with a strong focus on early employment and on skills upgrading (for those in need of this), suggests that they contribute to better integration outcomes in general and labour market integration in particular.

Labour market integration has only recently become an issue of policy concern. This seems to be partly due to the fact that the labour market outcomes of immigrants have been lower in the past decade than what they used to be. The reasons for this deterioration in outcomes are not entirely clear. In reaction to the unfavourable evolution of integration outcomes, there have been a number of initiatives over the past few years aimed at better accounting for the needs of immigrants in the Austrian Public Employment Service (AMS). For example, the AMS has implemented diversity training for its employees and immigrants will be included as a specific target group for active labour market policy as of 2012.

Austria has recently launched two major initiatives aimed at better utilising the skills potential of the resident population, and immigrants have been disproportionately represented in the corresponding labour market policy measures. There have also been several related programmes which indirectly target immigrants, with the aim of enhancing the supply of skilled labour in shortage occupations. The available evidence suggests that these have been particularly effective policy tools, and it seems important to continue along this promising route. Particular attention should be paid to placing more immigrants into the socalled "inplacement foundations" which provide tailor-made training for shortage occupations, co-financed by employers and the AMS. These seem to be particularly beneficial for immigrants, but they are currently underrepresented in this measure.

As in other OECD countries, language training is the single most important direct integration-related expenditure. Investment in German-language training used to be quite limited in the past, but has been increased considerably over the past three 
expenditure, but does not seem to be very effective and a better co-ordination among the stakeholders is needed.

Language training should be more skills- and vocationspecific.

\section{The incidence of "overqualification" among immigrants is higher than elsewhere in the OECD.}

The assessment of foreign qualifications seems to help immigrants, but it is highly complex and few immigrants take advantage of it.

\section{Immigrants would benefit from the accreditation of prior learning.}

Measures to improve the low educational outcomes of immigrant offspring years. The bulk of the expenditure is financed by the AMS, but other stakeholders also provide language training, and there is little co-ordination among them. The AMS courses are the only courses whose impact can be at least partly assessed, since information on the labour market status of past participants is available. While there has been no thorough investigation of its effect thus far, the fact that only about $20 \%$ of participants are in employment three months after the training, suggests that it may not be very effective.

The low transition rate from AMS-provided language training into employment could partly be due to the fact that it may not be sufficiently focused. Indeed, most language training targets low levels of mastery in German (A2-level), and skillsor vocation-specific language training on-the-job accounts for only a small part of the language training provided by the AMS. This is the type of training which seems to entail the most benefits, and its broader-based introduction should be considered.

The Austrian labour market strongly values formal qualifications, but immigrants often find their foreign qualifications discounted by Austrian employers. The discount is strongest for the highly-educated who have obtained their qualifications in lower-income countries. Only $40 \%$ of these actually work in a highly-skilled job compared with $70 \%$ of the native-born. $11 \%$ of highly-educated immigrants from lower-income countries even work in a low-skilled job. Indeed, the relatively high employment rate of immigrants in international comparison seems to be linked with a high incidence of "overqualification" - that is, of immigrants working in a job requiring only skills below their formal education level.

Cross-sectional data show a strong positive association between having a foreign degree formally assessed and the probability to be in highly-skilled employment, for migrants who have obtained their qualifications in lower-income countries. This suggests that the recognition process plays the role expected from it. However, relatively few immigrants seem to take advantage of this possibility, in spite of the fact that only a rather low fee is demanded from them. This seems to be at least partly due to the fact that the current infrastructure in this domain is particularly dispersed. The establishment of a one-stop-shop accepting applications for recognition in all domains and levels (and then handing them over internally to the competent authorities) would seem to be a promising first step which the authorities should consider. In addition, the finding that assessment helps in getting good jobs needs to be made more widely known to immigrants.

A major shortcoming in the current infrastructure for integration is the fact that there is no system in place for the accreditation of prior learning. One would expect immigrants to benefit disproportionately from the introduction of such measures, given that employers tend to be more uncertain about the qualifications and skills of immigrants who have obtained these in often very different contexts. For the outcome of such a competence assessment to be accepted on the labour market, the social partners need to be strongly involved.

Data from the OECD Programme for International Student Assessment (PISA) have shown that the differences in the education outcomes between the children of immigrants and the children of natives are particularly large in Austria, and immigrant offspring also lag well behind their counterparts in terms of educational 
would be

particularly

beneficial, with a

focus on education

at the age of three.

The current strong

focus on "mothertongue" education should be reconsidered.

\author{
More recent cohorts \\ of children of \\ immigrants face \\ larger difficulties \\ than previous ones, \\ and this requires \\ urgent policy \\ attention.
}

Immigrant offspring tend to be underrepresented in those tracks of vocational education that are particularly effective pathways for the school-towork transition. attainment levels. This tendency seems to be reinforced by early streaming in the school system. Early streaming would be less of a problem if pre-school education could compensate for the often unfavourable socio-economic background of the children of immigrants. However, in spite of some recent improvements, preschool education is under-developed in Austria. In addition, children of immigrants are underrepresented in pre-school education below the age of four, which is a particularly crucial age for integration. This is an issue which needs urgent policy attention. A wider and better targeted provision of pre-school education for children of immigrants at the critical age of three, along with early language support measures, would seem to entail important benefits - not only for the children themselves, but also possibly with respect to the labour market outcomes of their mothers. Indeed, there is a particularly strong and negative association between having small children and the labour market outcomes of immigrant women from lower-income countries.

While support measures to foster education outcomes for the children of immigrants, notably German language training, appear to be less developed than in other OECD countries, so-called "mother-tongue" education is rather well established. The reasons for this are not entirely clear, and it should be investigated whether this type of language training provides the benefits expected from it or whether the money spent on this would be better invested into additional Germanlanguage training, in particular at the critical ages of three and four. Language support measures in schools are rather heterogeneous with respect to their availability and quality and a stronger co-ordination at the federal level would help to enhance the consistency of the current framework on the basis of common minimum standards.

Across all groups of offspring of immigrants one observes significantly larger gaps among the younger cohort - in particular for the children with parents from Turkey. Due to a lack of longitudinal data, it is not possible to discern whether this is due to the fact that the offspring of immigrants have generally more difficulties in the early years after school-leaving and then catch up or whether this is a cohort effect (i.e. young children of immigrants have more difficulties than older cohorts used to have). Given the significant and growing number of children of immigrants who are about to enter the labour market in Austria, this is an issue which requires urgent policy attention.

The transition from lower to upper secondary education appears to be a decisive step in the process of school-to-work transition. Several pathways are open to students at this stage. Apprenticeships provide a smooth school-to-work transition and are associated with good labour market outcomes, both for immigrant offspring and the children of natives. However, children of immigrants tend to be underrepresented in this pathway. They are also less likely to proceed to and to complete higher vocational colleges after the end of lower secondary education, although this is a pathway that appears to yield particularly high employment rates for them. In contrast, immigrant offspring tend to be overrepresented in the intermediate track of vocational schooling that is less effective in promoting their labour market integration. It is thus important to identify the reasons for the apparently disadvantageous choices among the available pathways which immigrants make, and to take remedial action. 
Immigrant offspring are largely overrepresented among early school leavers, and a concerted policy effort is needed to tackle this.

The public sector needs to engage more strongly in the integration of immigrant offspring.

The unfavourable labour market outcomes even of immigrant offspring with good Austrian qualifications point to structural obstacles in the labour market.

The issue of discrimination against migrants has not been very present in the public debate, and testing studies would help to raise awareness about this issue.
Children of immigrants are three times more likely to leave the school system without an upper secondary qualification than the children of natives. As a consequence, they are also four times more likely to be low-qualified and neither in education nor in employment or training. Offspring with parents from Turkey are in a particular unfavourable situation, as one fifth belongs to this group at risk. There are only few measures in place to tackle this significant challenge, and more targeted action is needed. Although the AMS has recently reinforced its efforts to promote the qualification and labour market prospects of early school leavers, immigrant children have not yet been designated a specific target group in these measures.

One sector in which immigrant offspring are currently largely underrepresented is the public sector. By employing immigrants, the public sector acts as a role model for the private sector. Employment in the public sector can also contribute to enhancing the understanding of immigrants' needs by public institutions. When immigrants are employed in certain key occupations such as teaching, they can also serve as a role model for others, notably immigrant youngsters. As a result, other OECD countries have recently taken strong efforts to increase employment of immigrants and - in particular - their offspring in the public sector, and these have met with some success. In Austria, however, apart from a few small-scale initiatives at the sub-federal level, there are no measures in place to enhance the presence of immigrants in public sector employment. It is important that the public sector, as a major employer with high visibility, engages more strongly in integration.

The large and persistent gaps in the labour market outcomes, even for immigrant offspring with good Austrian qualifications, point to the existence of other, structural obstacles to labour market integration, such as lack of networks or lack of familiarity with labour market functioning, as well as discrimination. To tackle the former two obstacles, other OECD countries have implemented a broad range of measures to bring immigrants and their children in contact with employers, and to provide them with knowledge about labour market functioning. In Austria, such measures have been limited to date, with the exception of mentorship. Their implementation on a wider basis should be considered.

In the public debate, as well as among employers in Austria, there seems to be little awareness of the possibility of discrimination in hiring. There have been no testing studies thus far that would demonstrate and quantify its existence. This is unfortunate, since testing has often revealed a much larger incidence of discrimination than is generally perceived. In the other OECD countries under review, it is not uncommon that persons with an immigrant-sounding name have to write three times as many applications to get an invitation to a job interview as persons without a migration background but an otherwise similar CV. A monitoring of discrimination would thus bring the issue into the limelight. Particular attention should be paid in this respect regarding small- and medium-sized enterprises, in which selective hiring processes tend to be more pronounced and which account for the bulk of employment in Austria. 
The institutional framework against discrimination needs to be reformed and complemented by more pro-active measures.
The current institutional framework against discrimination is both recent and dispersed. At the same time, the few cases currently formally treated can be assumed to be only the tip of the iceberg, if the experiences of other OECD countries are any indication. A reform of the anti-discrimination framework by reducing the number of different bodies involved could well entail efficiency gains. At the same time, the framework needs to be made more widely known to immigrants. Such a reform should be complemented by more pro-active diversity policy measures aimed at the diversification of recruitment channels by employers, which are currently lacking. 


\section{BIBLIOGRAPHY}

AMS Jugendliche Wien (2011), "Evaluierung der Dienstleistungen des AMS Jugendliche für Personen mit Migrationshintergrund", Vienna: Austrian Institute for SME Research.

Antalovsky, E., S. Herzog and A. Wolffhardt (2009), "Integrationsleitbilder und Integrationsbeiräte österreichischer Städte - Dossier zur Online-Befragung”, Project report, Vienna: Europaforum Wien.

Bacher, J. (2003), "Soziale Ungleichheit und Bildungspartizipation im weiterführenden Schulsystem Österreichs", in Österreichische Zeitschrift für Soziologie, Vol. 28 (3), pp. 3-32.

Bauböck, R. and H. Wimmer (1988), "Social partnership and 'foreigners policy': on special features of Austria’s guest worker system”, in European Journal of Political Research, Vol. 16, pp. 659-681.

Bauböck, R. (1996), “"Nach Rasse und Sprache Verschieden'- Migrationspolitik in Österreich von der Monarchie bis heute", IHS Political Science Series, Vol. 31, Vienna: IHS.

Bauer, W. T. (2008), “Zuwanderung nach Österreich”, online publication, Vienna: Österreichische Gesellschaft für Politikberatung und Politikentwicklung, available at: http://www.politikberatung.or.at/typo3/fileadmin/02_Studien/8_Migration/zuwanderungnachoesterr eich.pdf (20 May 2011).

Behtoui, A. (2008), "Informal Recruitment Methods and Disadvantages of Immigrants in the Swedish Labour Market", in Journal of Ethnic and Migration Studies", Vol. 34 (3), pp. 411-430.

Bichl, N., C. Schmid and W. Szymanski (forthcoming), "Im Hamsterrad der Fremdengesetzgebung - , RotWeiß-Rot-Karte', Anwesenheitspflicht für Asylwerber und Schubhaft für Minderjährige", in MigraLex 2/2011, pp. 49-60.

Bichl, N., C. Schmid and W. Szymanski (2010), Das neue Recht der Arbeitsmigration, Vienna: Neuer wissenschaftlicher Verlag.

Biffl, G. (1990), “SOPEMI Report on Labour Migration - Austria 1989/90”, Vienna: WIFO.

Biffl, G. (1991), “SOPEMI Report on Labour Migration - Austria 1990/91”, Vienna: WIFO.

Biffl, G. (1992), “SOPEMI Report on Labour Migration - Austria 1991/1992”, Vienna: WIFO.

Biffl, G. (1999), “SOPEMI Report on Labour Migration - Austria 1998/99”, Vienna: WIFO.

Biffl, G. (2006), “SOPEMI Report on Labour Migration - Austria 2006”, Vienna: WIFO.

Biffl, G. (2010a), "Migration and Labour Integration in - Austria. SOPEMI Report on Labour Migration Austria 2009/10", Vienna: WIFO. 
Biffl, G. (2010b), "Impact of Migration on Employment in Austria and the role of integration policies (2000-2009)", Report for the IOM Independent Network of Labour Migration \& Integration Experts (LMIE-INET), Danube University Krems.

Biffl, G., J. Bock-Schappelwein, A. Steinmayr and A. Riesenfelder (2008), "Migrantinnen und Migranten auf dem Wiener Arbeitsmarkt", Study commissioned by the WAFF, Vienna: WIFO.

BMASK (2010a), “Arbeitsmarktpolitik im Jahr 2009”, Vienna: BMASK.

BMASK (2010b), "Basisinformationsbericht Österreich, Berichtsjahr 2009: Institutionen, Verfahren, Massnahmen", Vienna: BMASK.

Bock-Schappelwein, J., C. Bremberger, R. Hierländer, P. Huber, K. Knittler, J. Berger, H. Hofer, M. Miess and L. Strohner (2009): Die ökonomischen Wirkungen der Immigration in Österreich 1989-2007, WIFO Monographies 1/2009, Vienna: WIFO, IHS.

Böheim, R., K. Himpele, H. Mahringer and C. Zulehner (2011), “The Gender Pay Gap in Austria: Tamensi Movetur!", WIFO Working Paper No. 394, Vienna: WIFO.

Breit, S. (2007), "Sozialisationsbedingungen von Schülerinnen und Schülern mit Migrationshintergund", in C. Schreiner and U. Schwantner (eds.), PISA 2006: Österreichischer Expertenbericht zum Naturwissenschafts-Schwerpunkt, Graz: Leykamp.

Card, D. (2004), “Is the New Immigration Really so Bad?”, in The Economic Journal, Vol. 115, No. 507, pp. 300-323.

Carlsson, M. and D.-O. Rooth (2006), "Evidence of Ethnic Discrimination in the Swedish Labor Market Using Experimental Data", IZA Discussion Paper No. 2281, Bonn: IZA.

Clausen, J., E. Heinesen, H. Hummelgaard, L. Husted and M. Rosholm (2008), "The Effect of Integration Policies on the Time until Regular Employment of Newly Arrived Immigrants: Evidence from Denmark", IZA Discussion Paper No. 3849, Vienna: IZA.

Deutsch, H., E. Neurath, I. Nowotny and R. Seitz (2010), “Ausländerbeschäftigungsrecht”, Handbuch des österreichischen Arbeitsmarktrechts, "Vol. 3, Vienna: Verlag des österreichischen Gewerkschaftsbundes.

Dornmayr, H. (2010), "Bericht zur Situation der Jugendbeschäftigung und Lehrlingsausbildung in Österreich 2008-2009”, in IBW Research Brief, Vol. 63, Vienna: IBW.

Duell, N., P. Tergeist, U. Bazant and S. Cimper (2010), “Activation Policies in Switzerland”, OECD Social Employment and Migration Working Paper No. 116, OECD publishing, Paris.

European Commission (2007), "Discrimination in the European Union, Special Eurobarometer 263, Wave 65.4.”, Brussels, European Commission, available at:

http://ec.europa.eu/public_opinion/archives/ebs/ebs_263_sum_en.pdf (20 May 2011).

Fassmann, H. and R. Münz (1995), Einwanderunsgland Österreich? Historische Migrationsmuster, aktuelle Trends und politische Maßnahmen, Vienna: Jugend und Volk.

Gächter, A. (2008), "Migrationspolitik in Österreich seit 1945", Working papers on Migration and Social Mobility, Vol. 12 (unpublished), Vienna: ZSI, available at: https://www.zsi.at/attach/p1208vukovic.pdf (20 May 2011). 
Gächter, A. (2010), "Die Verwertung der Bildung ist in allen Bundesländern das größere Problem als die Bildung selbst", in M. Oberlechner and G. Hetfleisch (eds.), Integration, Rassismen und Weltwirtschaftskrise, Vienna: Braumüller, pp. 129-172.

Gächter, A. and S. Smoliner (2010), "How well does education travel? Education and occupation with and without migration", FIW Research Reports 2009/2010, Vol. 10 / Migration Issues, Vienna: FIW.

Gleichbehandlungsanwaltschaft Österreich (2010), “Anwaltschaft für Gleichbehandlung. Gemeinsamer Bericht 2008/2009", Vienna, available at: http://www.gleichbehandlungsanwaltschaft.at/DocView.axd?CobId=42115 (20 May 2011).

Havinga, T. (2002), "The Effects and Limits of Anti-discrimination Law in the Netherlands", in International Journal of the Sociology of Law, Vol. 30, pp. 75-90.

Herzog-Punzenberger, B. (2007), "Gibt es einen Staatsbürgerschaftsbonus? Unterschiede in der Bildung und auf dem Arbeitsmarkt anhand der österreichischen Volkszählungsdaten 2001 - Ergebnisse für die zweite Generation der Anwerbergruppen", in H. Fassmann (ed.), 2. Österreichischer Migrationsund Integrationsbericht 2001-2006, Vienna and Klagenfurt: Drava, pp. 242-245.

Hofer, H. and P. Huber (2001), "Wage and Mobility Effects of Trade and Migration on the Austrian Labour Market", Economic Series, Vol. 97, Vienna: IHS.

Hofer, H., K.Pichelmann and U. Schuh (2001), "Price and Quantity Adjustments in the Austrian Labour Market", in Applied Economics, Vol. 33, pp. 581-592.

Hofer, H. and C. Lietz (2004), "Labour market effects of apprenticeship training in Austria", in International Journal of Manpower, Vol. 25 (1), pp. 104-122.

Hofer, H. and R. Winter-Ebmer (2007), "Regulation of the Austrian Labor Market", in Federal Ministry of Economics and Technology (ed.), Growth Aspects of Labour Market Policy, Report for the Federal Ministry of Economics and Technology, Bonn, pp. 28-51.

Huber, P., K. Nowotny and J. Bock-Schappelwein (2010), "Qualification Structure - Over- and Underqualification of the Foreign Born in Austria and the EU", FIW Research Reports 2009/10, No. 08, Vienna: FIW.

Klagsverband zur Durchsetzung der Rechte von Diskriminierungsopfern (2010), "Jahresbericht 2010, Vienna", available at: http://www.klagsverband.at/dev/wpcontent/uploads/2008/05/rz_20110203_jahresbericht_screen.pdf (20 May 2011).

Klinger, S. and M. Rebien (2009), "Betriebsbefragung: Soziale Netzwerke helfen bei der Personalsuche", IAB-Kurzbericht 24/2009, Nürnberg: IAB.

Knittler, K. (2011), "Intergenerationale Bildungsmobilität - Bildungsstruktur junger Erwachsener im Alter von 15 bis 34 Jahren im Vergleich mit jener ihrer Eltern", in Statistische Nachrichten, Vol. 4/2011, Vienna: Statistics Austria, pp. 252-266.

Kohlbacher, J. and U. Reeger (2007), “Wohnverhältnisse und Segregation”, in H. Fassmann (ed.), 2. Österreichischer Migrations- und Integrationsbericht 2001-2006, Vienna and Klagenfurt: Drava, pp. 305-332. 
Lebhart, G. and S. Marik-Lebeck (2007), "Zuwanderung nach Österreich: aktuelle Trends”, in H. Fassmann (ed.), 2. Österreichischer Migrations- und Integrationsbericht 2001-2006, Vienna and Klagenfurt: Drava, pp. 145-162.

Lechner, M., R. Miquel, S. Werner and S. Wiehler (2007), "Mikroökonometrische Evaluierung der Instrumente der aktiven Arbeitsmarktpolitik in Österreich", Project report, Vienna: SIAW.

Liebig, T. (2009), "Jobs for Immigrants: Labour Market Integration in Norway", OECD Social, Employment and Migration Working Paper No. 94, OECD publishing, Paris.

Lutz, H., H. Mahringer and A. Pöschl (2005),“Evaluierung der österreichischen Arbeitsmarktförderung 2000-2003", Vienna: WIFO.

Magistratsabteilung 17 (2009), “Integrations- und Diversitätsmonitor der Stadt Wien 2009”, Vienna.

Manolakos, T. and K. Sohler (2005), "Gleiche Chancen im Betrieb? Diskriminierung von MigrantInnen am Wiener Arbeitsmarkt”, Research report for Equal EP “Gleiche Chancen im Betrieb”, Vienna: European Centre for Social Welfare Policy and Research.

Neyer, G. R. (1985), “Ausländische ArbeitnehmerInnen in Österreich”, in H. Wimmer (ed.), Ausländische Arbeitskräfte in Österreich, Forschungsergebnisse No. 9, Vienna: Bundesministerium für soziale Administration.

Nowotny, I. (2007), “Das Ausländerbeschäftigungsgesetz. Die Regelung des Zugangs von AusländerInnen zum österreichischen Arbeitsmarkt", in H. Fassmann (ed.), 2. Österreichischer Migrations- und Integrationsbericht 2001-2006, Vienna and Klagenfurt: Drava, pp. 47-73.

OECD (2007), Jobs for Immigrants (Vol. 1): Labour market integration in Australia, Denmark, Germany and Sweden, OECD publishing, Paris.

OECD (2008a), Jobs for Immigrants (Vol. 2): Labour market integration in Belgium, France, the Netherlands and Portugal, OECD publishing, Paris.

OECD (2008b), Employment Outlook 2008, OECD publishing, Paris.

OECD (2009a), Economic Survey - Austria, OECD publishing, Paris.

OECD (2009b), OECD Reviews of Migrant Education - Austria, OECD publishing, Paris.

OECD (2010a), Equal Opportunities? The Labour Market Integration of the Children of Immigrants, OECD publishing, Paris.

OECD (2010b), Learning for Jobs. OECD Reviews of Vocational Education and Training - Austria, OECD publishing, Paris.

OECD (2010c), PISA 2009 Results: Overcoming Social Background: Equity in Learning Opportunities and Outcomes (Volume II), OECD publishing, Paris.

OECD (2011a), Naturalisation: A Passport for the Better Integration of Immigrants?, OECD publishing, Paris.

OECD (2011b), International Migration Outlook 2011, OECD publishing, Paris. 


\section{DELSA/ELSA/WD/SEM(2011)12}

Österreichische Universitätenkonferenz (2009), "Positionspapier der Österreichischen Universitätskonferenz: Non-formales und informelles Lernen", position paper, Vienna, available at: http://www.reko.ac.at/upload/Positionspapier_nonformales_und_informelles_Lernen_ENDVERSION_2009.pdf (20 May 2011).

Perchinig, B. (2009), “All you need to know to become an Austrian: Naturalisation policy and citizenship testing in Austria", in: E. Ersboll, D. Kostakopoulou and R. van Oers (eds.), A redefinition of belonging? Language and integration tests in Europe, Leiden: Brill.

Reichel, D. (2011), Staatsbürgerschaft und Integration - Die Bedeutung der Einbürgerung für MigrantInnen in Hinblick auf ihre soziale und ökonomische Integration, Wiesbaden: VS Verlag für Sozialwissenschaften.

Riesenfelder, A. and P. Wetzel (2010), “Die Leiharbeit in der Krise? ”, Project report, Vienna: L \& R Sozialforschung.

Satner, F. and E. Adam-Maxova (2007), "Vergleichende Reaktionen auf afrikanische und österreichische Stellensuchende: eine Feldstudie", in E. Ebermann (ed.), Afrikaner in Wien. Zwischen Mystifizierung und Verteufelung. Erfahrung und Analysen, Afrika und ihre Diaspora Vol. 3, $3{ }^{\text {rd }}$ Edition, Vienna: Lit, pp. $184 \mathrm{ff}$.

Schindlauer, D. (2007), "Report on Measures to Combat Discrimination -Austria", paper edited by the European Network of Legal Experts in the Non-Discrimination Field, Brussels: European Commission.

Sherwyn, D. (2009), Employment Class and Collective Actions: Proceedings of the New York University $56^{\text {th }}$ Annual Conference on Labor, Alphen aan den Rijn.

Steiner, M. (2009), "Early School Leaving in Österreich 2008 - Ausmaß, Unterschiede, Beschäftigungswirkung", research report commissioned by the Chamber of Labour, Vienna: IHS.

Van de Voorde, M. and H. de Bruijn (2010), "Mainstreaming the Flemish Employment Equity and Diversity Policy", in OECD (ed.): Equal Opportunities? The Labour Market Integration of the Children of Immigrants, pp. 229-242, OECD publishing, Paris.

Weber, A. and H. Hofer (2004a), "Active job search programs as a promising tool? A microeconometric evaluation for Austria", IZA Discussion Paper No. 1075, Bonn: IZA.

Weber, A. and H. Hofer (2004b), "Employment Effects of Early Interventions on Job Search Programs", IZA Discussion Paper No. 1076, Bonn: IZA.

Weiss, H. and A. Unterwurzacher (2007), "Soziale Mobilität durch Bildung? Bildungsbeteiligung von MigrantInnen”, in H. Fassmann. (ed.), 2. Österreichischer Migrations- und Integrationsbericht 2001-2006, Vienna and Klagenfurt: Drava, pp. 227-240.

Zucha, V. (2003), "Diskriminierung und Benachteiligung von MigrantInnen am Arbeitsplatz: Formen und Faktoren der Benachteiligung", Research report, Vienna: SORA, available at: http://www.gleichechancen.at/down/03079Zuwanderer.pdf (20 May 2011). 


\section{GLOSSARY}

AMS

ALMP

APL

BMASK

BMI

BMUKK

BMWA

ECEC

EIF

ENIC - NARIC

ERF

FIW

$\mathrm{IAB}$

IBW

IHS

ILO

ICMPD
Arbeitsmarktservice Österreich

(Austrian Public Employment Service)

Active Labour Market Policy

Accreditation of Prior Learning

Bundesministerium für Arbeit, Soziales und Konsumentenschutz

(Federal Ministry of Labour, Social Affairs and Consumer Protection)

Bundesministerium für das Innere

(Federal Ministry for the Interior)

Bundesministerium für Unterricht, Kunst und Kultur

(Federal Ministry for Education, Arts and Culture)

Bundesministerium für Wirtschaft und Arbeit

(Federal Ministry for Economy and Labour)

Early Childhood Education and Care

European Fund for Integration

European Network of Information Centres - National Academic Recognition Information Centre

European Refugee Fund

Kompetenzzentrum "Forschungszentrum Internationale Wirtschaft"

(Research Centre International Economics)

Institut für Arbeitsmarkt- und Berufsforschung

(Institute for Employment Research)

Institut für Bildungsforschung der Wirtschaft

(Institute for Research on Qualifications and Training of the Austrian Economy)

Institut für Höhere Studien

(Institute for Advanced studies)

International Labour Organization

International Centre for Migration Policy Development 
ISCED

ISEI

IZA

KMI

NEET

NGO

ÖIF

PISA

SIAW

SORA

VET

WAFF

WIFO
International Classification of Education

International Socio-Economic Index of Occupational Status

Institut zur Zukunft der Arbeit

(Institute for the Study of Labour)

Kommission für Migrations- und Integrationsforschung

(Commission for Migration and Integration Research)

Neither in Employment nor Education or Training

Non-Governmental Organization

Österreichischer Integrationsfonds

(Austrian Integration Fund)

Programme for International Student Assessment

Schweizerisches Institut für Aussenwirtschaft und Angewandte Wirtschaftsforschung

(Swiss Institute for International Economics and Applied Economic Research)

SORA Institute for Social Research and Consulting

Vocational Education and Training

Wiener ArbeitnehmerInnen Förderungsfond

(Vienna Employment Promotion Fund)

Österreichisches Institut für Wirtschaftsforschung

(Austrian Institute for Economic Research) 
DELSA/ELSA/WD/SEM(2011)12

ANNEX

A1. Education level and labour market outcomes by country-of-origin group and gender in Austria, aged 15-64, 2009/2010 average

\begin{tabular}{|c|c|c|c|c|c|c|c|c|c|c|c|c|}
\hline & & \multirow[b]{2}{*}{ Native-born } & \multicolumn{10}{|c|}{ Foreign-born } \\
\hline & & & \begin{tabular}{|l} 
EU15 (without \\
Austria) + \\
Switzerland
\end{tabular} & $\begin{array}{c}\text { EU12 } \\
\text { (new } \\
\text { members) }\end{array}$ & $\begin{array}{l}\text { Former } \\
\text { Yugoslavia } \\
\text { (excl. } \\
\text { Slovenia) }\end{array}$ & Turkey & $\begin{array}{l}\text { Asia } \\
\text { (excl. } \\
\text { Russia) }\end{array}$ & Africa & $\begin{array}{l}\text { Latin } \\
\text { America }\end{array}$ & $\begin{array}{c}\text { other } \\
\text { Eastern } \\
\text { Europe (incl. } \\
\text { Russia) }\end{array}$ & other & $\begin{array}{c}\text { All } \\
\text { foreign- } \\
\text { born }\end{array}$ \\
\hline \multicolumn{13}{|c|}{ Total } \\
\hline Percenta & e of all immigrants & & 18.3 & 17.3 & 32.3 & 14.6 & 8.5 & 3.0 & 1.5 & 3.1 & 1.3 & 100 \\
\hline \multirow{3}{*}{$\begin{array}{l}\text { Education } \\
\text { al Level }\end{array}$} & Low & 20 & -9 & -4 & 21 & 51 & 15 & 9 & 6 & 2 & -11 & 13 \\
\hline & Medium & 64 & -9 & 0 & -10 & -38 & -27 & -23 & -15 & -29 & -36 & -15 \\
\hline & High & 16 & 19 & 4 & -10 & -13 & 11 & 14 & 8 & 27 & 47 & 2 \\
\hline \multirow{3}{*}{\multicolumn{2}{|c|}{$\begin{array}{l}\text { Participation rate } \\
\text { Employment rate } \\
\text { Unemployment rate }\end{array}$}} & 75.5 & +2.1 & -3.9 & -2.5 & -11.1 & -6.8 & -1.3 & -1.8 & -8.7 & -9.5 & -3.8 \\
\hline & & 72.7 & +1.3 & -6.9 & -5.5 & -18.1 & -10.8 & -9.1 & -5.7 & -15.5 & -9.9 & -7.3 \\
\hline & & 3.8 & +0.9 & +4.4 & +4.2 & +11.6 & +6.1 & +10.6 & +5.3 & +10.7 & .. & +5.1 \\
\hline \multicolumn{13}{|c|}{ Men } \\
\hline \multicolumn{2}{|c|}{ Percentage of all immigrants } & & 18.6 & 14.2 & 33.6 & 16.3 & 8.8 & 3.8 & .. & 2.4 & .. & 100 \\
\hline \multirow{3}{*}{$\begin{array}{l}\text { Education } \\
\text { al Level }\end{array}$} & Low & 16.3 & -7 & -2 & +16 & +48 & +16 & +8 & .. & +5 &.. & +14 \\
\hline & Medium & 66.1 & -15 & +1 & -4 & -34 & -27 & -25 & .. & -24 & .. & -14 \\
\hline & High & 17.6 & +22 & +1 & -12 & -15 & +11 & +17 & .. & +20 & .. & +1 \\
\hline \multirow{3}{*}{\multicolumn{2}{|c|}{$\begin{array}{l}\text { Participation rate } \\
\text { Employment rate } \\
\text { Unemployment rate }\end{array}$}} & 80.2 & +4.1 & -0.9 & -1.6 & +1.7 & -2.2 & +4.8 & .. & +0.3 & .. & +0.4 \\
\hline & & 77.1 & +3.5 & -3.9 & -5.1 & -8.5 & -9.0 & -5.4 & .. & -12.8 & .. & -4.4 \\
\hline & & 3.9 & +0.5 & +3.8 & +4.6 & +12.4 & +8.8 & +11.8 & .. & +16.3 & .. & +5.9 \\
\hline \multicolumn{13}{|c|}{ Women } \\
\hline \multicolumn{2}{|c|}{ Percentage of all immigrants } & & 18.0 & 20.2 & 31.2 & 13.0 & 8.1 & 2.2 & .. & 3.8 & .. & 100 \\
\hline \multirow{6}{*}{$\begin{array}{c}\text { Education } \\
\text { al Level }\end{array}$} & Low & 23.3 & -12 & -6 & +26 & +54 & +14 & +12 & .. & 0 & .. & +13 \\
\hline & Medium & 62.7 & -4 & 0 & -17 & -44 & -26 & -21 & .. & -32 & .. & -16 \\
\hline & High & 14.1 & +16 & +7 & -9 & -10 & +12 & +9 & .. & +32 & .. & +3 \\
\hline & articipation rate & 70.8 & +0.4 & -4.1 & -3.3 & -26.3 & -11.4 & -13.8 & .. & -11.8 & .. & -7.1 \\
\hline & mployment rate & 68.1 & -0.5 & -7.2 & -5.7 & -29.7 & -12.5 & -17.6 & .. & -15.1 & .. & -9.4 \\
\hline & nemployment rate & 3.8 & +1.2 & +4.9 & +3.8 & +9.8 & +2.6 & $\ldots$ & .. & +6.2 & .. & +4.1 \\
\hline
\end{tabular}

Note: Educational level and labour market outcomes for immigrants are shown in percentage points differences vis-à-vis native-born. ".."means not significant for publication.

Source: Austrian Microcensus (data provided by Statistics Austria). 
DELSA/ELSA/WD/SEM(2011)12

Table A2. Population structure by age, migrant status and gender, 2009/2010

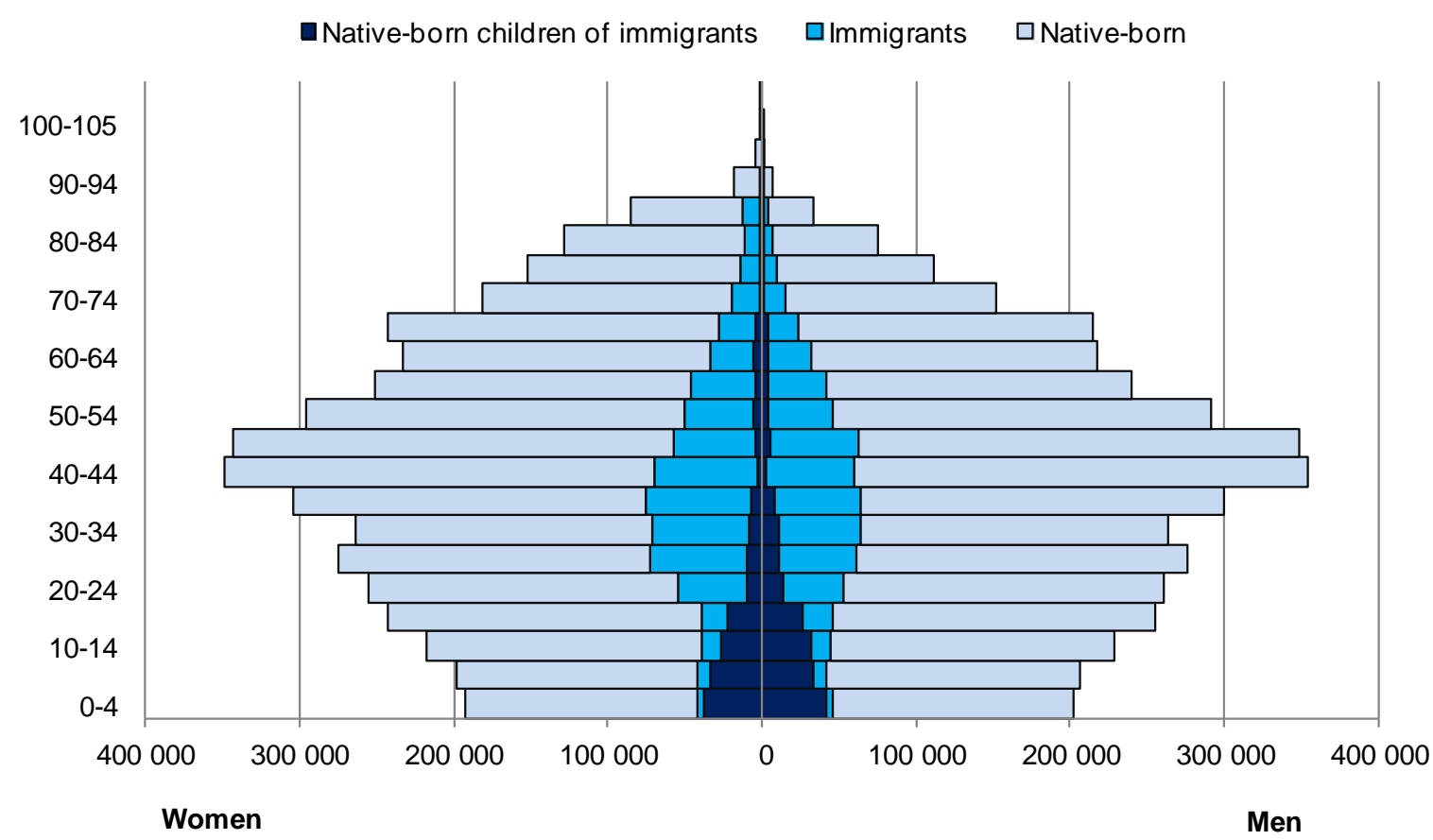

Source: Austrian Microcensus (data provided by Statistics Austria). 
Table A3.1. Labour market outcomes of immigrants in Vienna and the remainder of Austria, aged 15-64, 2008-2010

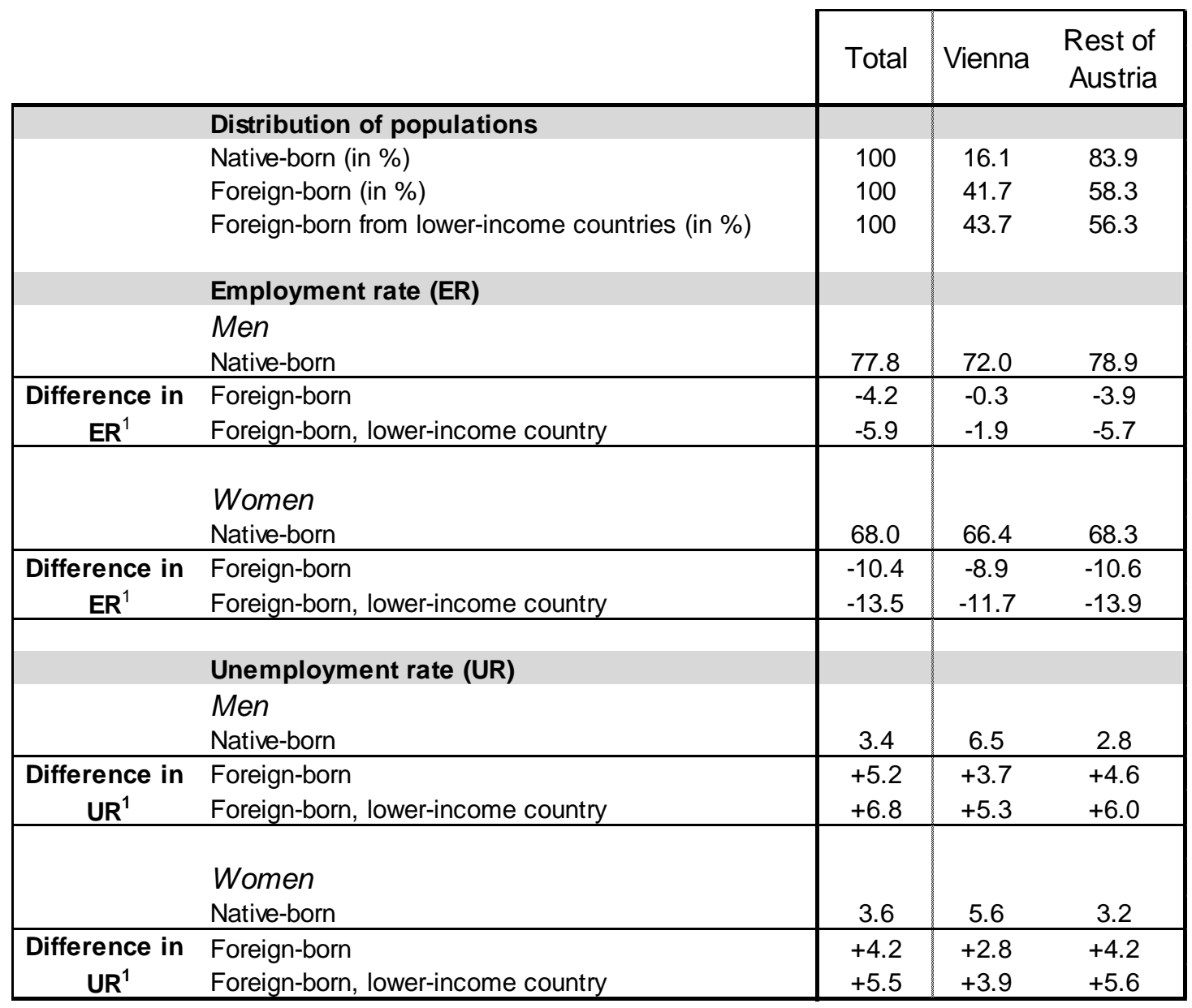

Note 1: Foreign-born minus native-born.

Source: Microcensus Austria (data provided by Statistics Austria). 
Table A3.2. Labour market outcomes of the children of immigrants in Vienna and the remainder of Austria, aged 20-29, 2008-2010

\begin{tabular}{|c|c|c|c|c|}
\hline & & Total & Vienna & $\begin{array}{l}\text { Rest of } \\
\text { Austria }\end{array}$ \\
\hline & Distribution of populations & & & \\
\hline & Children of natives (in \%) & 100 & 21.3 & 78.7 \\
\hline & Native-born, children of immigrants (in \%) & 100 & 52.0 & 48.0 \\
\hline & Native-born, children of immigrants from lower-income countries (in \%) & 100 & 50.9 & 49.1 \\
\hline & Employment rate (ER) & & & \\
\hline & Men & & & \\
\hline & Children of natives & 82.0 & 73.1 & 84.1 \\
\hline Difference & Native-born, children of immigrants & -3.5 & +1.7 & -1.9 \\
\hline in $\mathbf{E} \mathbf{R}^{1}$ & Native-born, children of immigrants from lower-income countries & -3.6 & +1.5 & -2.3 \\
\hline & Women & & & \\
\hline & Children of natives & 75.7 & 66.9 & 78.0 \\
\hline Difference & Native-born, children of immigrants & -4.8 & -0.8 & -2.5 \\
\hline in $\mathbf{E} \mathbf{R}^{1}$ & Native-born, children of immigrants from lower-income countries & -5.7 & -0.4 & -4.3 \\
\hline & Unemployment rate (UR) & & & \\
\hline & Men & & & \\
\hline & Children of natives & 6.1 & 11.0 & 5.0 \\
\hline Difference & Native-born, children of immigrants & +5.2 & +1.6 & +5.0 \\
\hline in $\mathbf{U} \mathbf{R}^{1}$ & Native-born, children of immigrants from lower-income countries & +5.7 & +2.8 & +5.1 \\
\hline & Women & & & \\
\hline & Children of natives & 5.6 & 8.4 & 5.0 \\
\hline Difference & Native-born, children of immigrants & +5.3 & +6.3 & +2.6 \\
\hline in $\mathbf{U R}^{1}$ & Native-born, children of immigrants from lower-income countries & +6.0 & +6.0 & +3.8 \\
\hline & Share of low-educated ${ }^{2}$ neet among 20-29 year old & & & \\
\hline & Men & & & \\
\hline & Children of natives & 3.2 & 5.3 & 2.7 \\
\hline $\begin{array}{l}\text { Percentage } \\
\text { points }\end{array}$ & Native-born, children of immigrants & +6.3 & +4.8 & +6.1 \\
\hline difference $^{1}$ & Native-born, children of immigrants from lower-income countries & +7.0 & +5.7 & +6.7 \\
\hline & Women & & & \\
\hline & Children of natives & 5.4 & 7.6 & 4.7 \\
\hline $\begin{array}{l}\text { Percentage } \\
\text { points }\end{array}$ & Native-born, children of immigrants & +5.5 & +5.4 & +3.9 \\
\hline difference ${ }^{1}$ & Native-born, children of immigrants from lower-income countries & +6.7 & +6.3 & +5.3 \\
\hline
\end{tabular}

Note: Persons in education were excluded for the calculation of the employment and unemployment rates. 1: Children of immigrants minus children of native-born. 2: "Low-educated" refers to lower secondary education and below (ISCED 0-2).

Source: Microcensus Austria (data provided by Statistics Austria). 
Table A4. Distribution of the labour force between different economic sectors in Austria, by country of birth and gender, aged 15-64, 2009/2010 average

\begin{tabular}{|c|c|c|}
\hline & Native-born & $\begin{array}{c}\text { Percentage-points difference } \\
\text { between foreign-born and } \\
\text { native-born }\end{array}$ \\
\hline \multicolumn{3}{|l|}{ Men } \\
\hline Agriculture, Forestry, Fishing & 6 & -4 \\
\hline Construction, Mining, Quarrying & 12 & +5 \\
\hline Manufacturing & 23 & -1 \\
\hline Electricity, Gas and Water Supply & 1 & -1 \\
\hline Wholesale and Retail Trade, Repair & 14 & 0 \\
\hline Tourism (Hotels and Restaurants) & 3 & +7 \\
\hline Transport and Communication & 8 & +2 \\
\hline Financial Intermediation & 4 & -2 \\
\hline Real Estate, Renting and Business Activities & 10 & 0 \\
\hline Public Administration, Compulsory Social Security & 8 & -7 \\
\hline Education & 4 & -1 \\
\hline Health and Social Work & 4 & -1 \\
\hline Other & 4 & +2 \\
\hline Total & 100 & \\
\hline \multicolumn{3}{|l|}{ Women } \\
\hline Agriculture, Forestry, Fishing & 5 & -4 \\
\hline Construction, Mining, Quarrying & 2 & -1 \\
\hline Manufacturing & 9 & +2 \\
\hline Electricity, Gas and Water Supply & 0 & 0 \\
\hline Wholesale and Retail Trade, Repair & 19 & -2 \\
\hline Tourism (Hotels and Restaurants) & 7 & +9 \\
\hline Transport and Communication & 3 & -1 \\
\hline Financial Intermediation & 4 & -2 \\
\hline Real Estate, Renting and Business Activities & 10 & +7 \\
\hline Public Administration, Compulsory Social Security & 7 & -4 \\
\hline Education & 10 & -5 \\
\hline Health and Social Work & 16 & 0 \\
\hline Other & 7 & +1 \\
\hline Total & 100 & \\
\hline
\end{tabular}

Note: Sectors constructed after ÖNACE-classification.

Source: Austrian Microcensus (data provided by Statistics Austria). 
Table A5. Percentage-point differences in the employment rate between foreign-born and native-born, by gender and educational attainment, aged 15-64 and not in education, 2008/2009

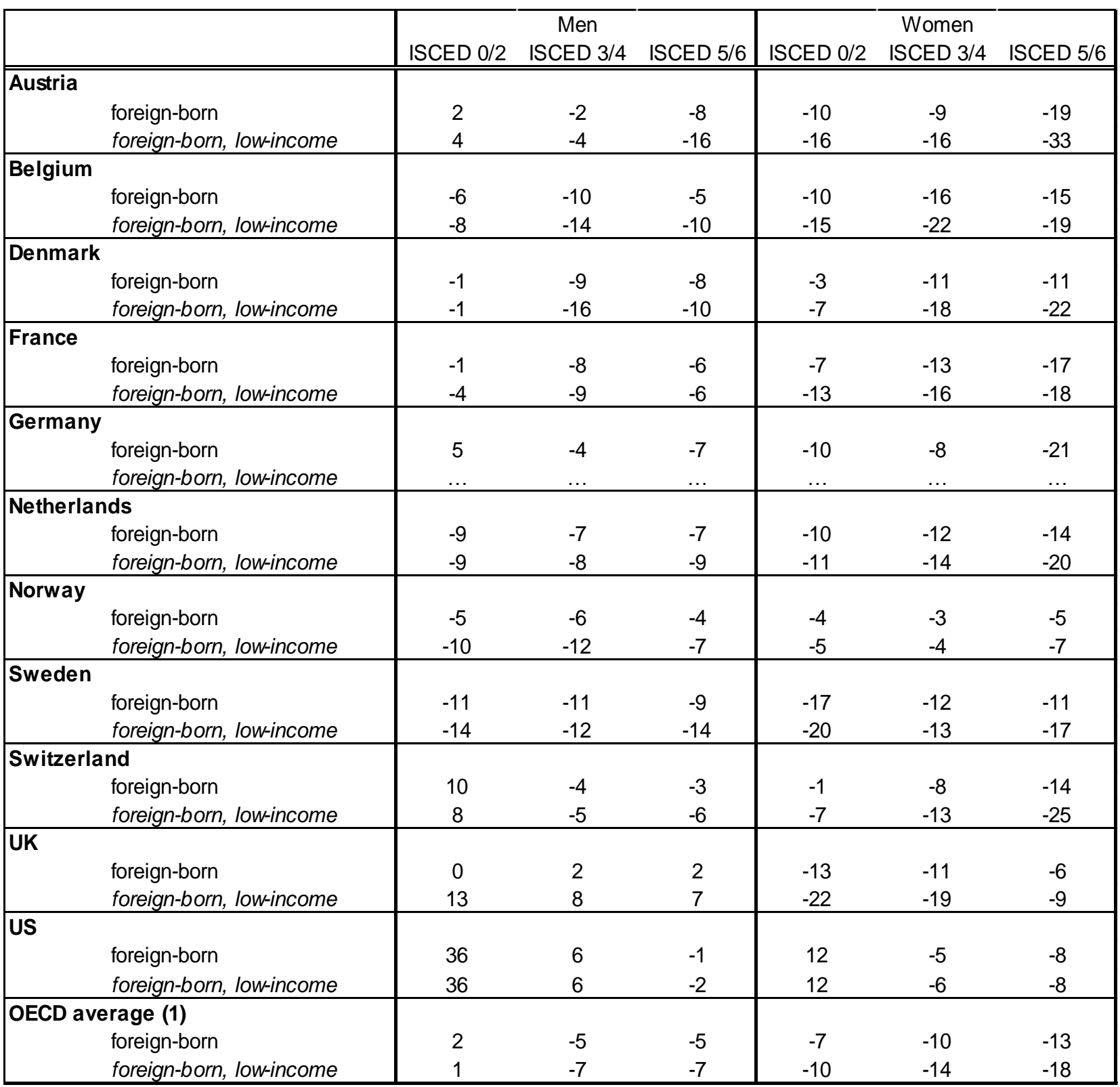

Note: Persons in (full-time) education have been excluded. 1: The OECD average refers to the unweighted average of the countries included in this table. "Foreign-born, low-income" refers to foreign-born from a lower-income country.

Source: European Community Labour Force Survey 2008/20099 and Current Population Survey March Supplement for the United States. 
DELSA/ELSA/WD/SEM(2011)12

Table A6. Labour market outcomes of highly-educated population in selected high-income countries, aged 15-64, 2008/2009

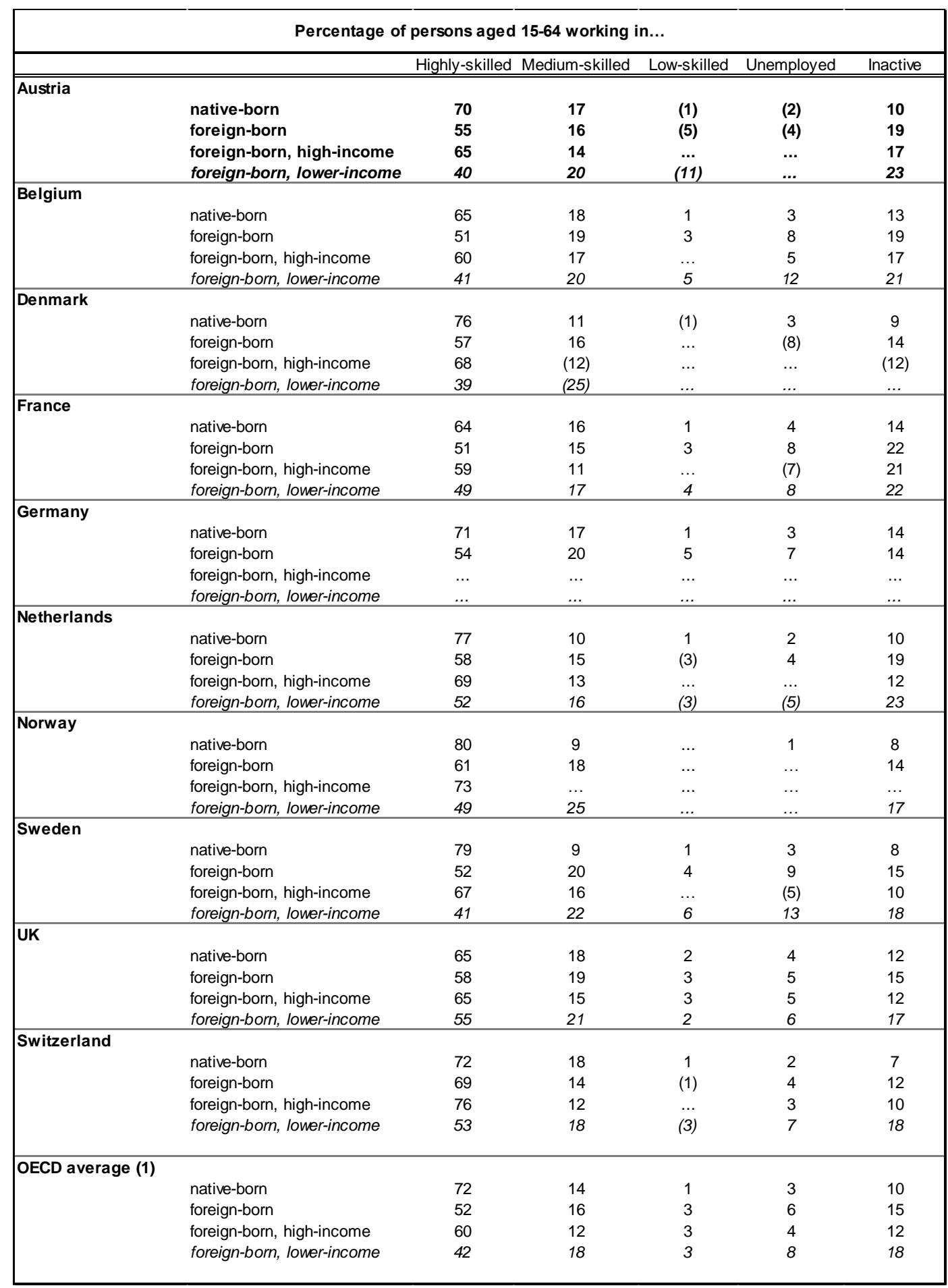

Note: "Foreign-born, high-income" refers to foreign-born from a high-income OECD country and "foreign-born, low-income" to all other countries. 1: The OECD average refers to the unweighted average of the countries included in this table.

Source: European Community Labour Force Survey 2009 and Current Population Survey March Supplement 2009 for the United States. 


\section{OECD SOCIAL, EMPLOYMENT AND MIGRATION WORKING PAPERS}

Most recent releases are:

No. 126 ARE RECENT IMMIGRANTS DIFFERENT? A NEW PROFILE OF IMMIGRANTS IN THE OECD BASED ON DIOC 2005/06 Sarah Widmaier and Jean-Christophe Dumont (2011)

No. 125 EARNINGS VOLATILITY AND ITS CONSEQUENCES FOR HOUSEHOLDS Danielle Venn (2011)

No. 124 CRISIS, RECESSION AND THE WELFARE STATE Willem Adema, Pauline Fron and Maxime Ladaique (2011)

No. 123 AGGREGATE EARNINGS AND MACROECONOMIC SHOCKS Andrea Bassanini (2011)

No. 122 REDISTRIBUTION POLICY AND INEQUALITY REDUCTION IN OECD COUNTRIES: WHAT HAS CHANGED IN TWO DECADES? Herwig Immervoll, Linda Richardson (2011)

No. 121 OVER-QUALIFIED OR UNDER-SKILLED Glenda Quintini (2011)

No. 120 RIGHT FOR THE JOB Glenda Quintini (2011)

No.119 THE MORAL-HAZARD AND LIQUIDITY EFFECTS OF UNEMPLOYMENT COMPENSATION IN BRAZIL: EVIDENCE AND POLICY IMPLICATIONS Andrea Bassanini (2011)

No. 118 EARLY MATERNAL EMPLOYMENT AND CHILD DEVELOPMENT IN FIVE OECD COUNTRIES Maria del Carmen Huerta, Willem Adema, Jennifer Baxter, Miles Corak, Mette Deding, Matthew C. Gray, Wen-Jui Han, Jane Waldfogel (2011)

No. 117 WHAT DRIVES INFLOWS INTO DISABILITY?EVIDENCE FROM THREE OECD COUNTRIES Ana Llena-Nozal and Theodora Xenogiani (2011)

No. 116 COOKING, CARING AND VOLUNTEERING: UNPAID WORK AROUND THE WORLD Veerle Miranda (2011)

No. 115 THE ROLE OF SHORT-TIME WORK SCHEMES DURING THE 2008-09 RECESSION Alexander Hijzen and Danielle Venn (2010)

No. 114 INTERNATIONAL MIGRANTS IN DEVELOPED, EMERGING AND DEVELOPING COUNTRIES: AN EXTENDED PROFILE

Jean-Christophe Dumont, Gilles Spielvogel and Sarah Widmaier (2010)

No. 113 ACTIVATION POLICIES IN JAPAN

Nicola Duell, David Grubb, Shruti Singh and Peter Tergeist (2010)

No. 112 ACTIVATION POLICIES IN SWITZERLAND

Nicola Duell and Peter Tergeist with contributions from Ursula Bazant and Sylvie Cimper (2010)

No. 111 ECONOMIC DETERMINANTS AND CONSEQUENCES OF CHILD MALTREATMENT

Lawrence M. Berger, Jane Waldfogel (forthcoming)

No. 110 DISTRIBUTIONAL CONSEQUENCES OF LABOR DEMAND ADJUSTMENTS TO A DOWNTURN: A MODEL-BASED APPROACH WITH APPLICATION TO GERMANY 2008-09

Herwig Immervoll, Olivier Bargain, Andreas Peichl, Sebastian Siegloch (2010)

A full list of Social, Employment and Migration Working Papers is available at www.oecd.org/els/workingpapers.

Other series of working papers available from the OECD include: OECD Health Working Papers. 
DELSA/ELSA/WD/SEM(2011)12

\section{RECENT RELATED OECD PUBLICATIONS:}

EQUAL OPPORTUNITIES? The Labour Market Integration of the Children of Immigrants (2010), via OECD Bookshop OECD REVIEWS OF LABOUR MARKET AND SOCIAL POLICIES: ESTONIA (2010), www.oecd.org/els/estonia2010 JOBS FOR YOUTH: GREECE (2010), www.oecd.org/employment/youth JOBS FOR YOUTH: DENMARK (2010), www.oecd.org/employment/youth OECD REVIEWS OF LABOUR MARKET AND SOCIAL POLICIES: ISRAEL (2010), www.oecd.org/els/israel2010

JOBS FOR YOUTH: UNITED STATES (2009), www.oecd.org/employment/youth JOBS FOR YOUTH: POLAND (2009), www.oecd.org/employment/youth OECD EMPLOYMENT OUTLOOK: Tackling the Jobs Crisis (2009), www.oecd.org/els/employment/outlook DOING BETTER FOR CHILDREN (2009), www.oecd.org/els/social/childwellbeing SOCIETY AT A GLANCE - ASIA/PACIFIC EDITION (2009), www.oecd.org/els/social/indicators/asia OECD REVIEWS OF LABOUR MARKET AND SOCIAL POLICIES: SLOVENIA (2009), www.oecd.org/els/slovenia2009 INTERNATIONAL MIGRATION OUTLOOK: SOPEMI (2010) www.oecd.org/els/migration/imo

PENSIONS AT A GLANCE 2009: Retirement-Income Systems in OECD Countries (2009), www.oecd.org/els/social/pensions/PAG

JOBS FOR YOUTH: FRANCE (2009), www.oecd.org/employment/youth SOCIETY AT A GLANCE 2009 - OECD Social Indicators (2009), www.oecd.org/els/social/indicators/SAG JOBS FOR YOUTH: AUSTRALIA (2009), www.oecd.org/employment/youth OECD REVIEWS OF LABOUR MARKET AND SOCIAL POLICIES: CHILE (2009), www.oecd.org/els/chile2009 PENSIONS AT A GLANCE - SPECIAL EDITION: ASIA/PACIFIC (2009),www.oecd.org/els/social/pensions/PAG SICKNESS, DISABILITY AND WORK: BREAKING THE BARRIERS (VOL. 3) - DENMARK, FINLAND, IRELAND AND THE NETHERLANDS (2008), www.oecd.org/els/disability GROWING UNEQUAL? Income Distribution and Poverty in OECD Countries (2008), www.oecd.org/els/social/inequality JOBS FOR YOUTH: JAPAN (2008), www.oecd.org/employment/youth JOBS FOR YOUTH: NORWAY (2008), www.oecd.org/employment/youth JOBS FOR YOUTH: UNITED KINGDOM (2008), www.oecd.org/employment/youth JOBS FOR YOUTH: CANADA (2008), www.oecd.org/employment/youth JOBS FOR YOUTH: NEW ZEALAND (2008), www.oecd.org/employment/youth JOBS FOR YOUTH: NETHERLANDS (2008), www.oecd.org/employment/youth For a full list, consult the OECD online Bookshop at www.oecd.org/bookshop. 